\title{
DINÂMICA DA ÁGUA EM TERRAÇOS DE INFILTRAÇÃO
}

\author{
LUCIANA GOMES CASTRO
}

Tese apresentada à Escola Superior de Agricultura "Luiz de Queiroz", Universidade de São Paulo, para obtenção do título de Doutor em Agronomia, Área de concentração: Solos e Nutrição de Plantas.

PIR A C I C A B A

Estado de São Paulo - Brasil

Outubro - 2001 


\title{
DINÂMICA DA ÁGUA EM TERRAÇOS DE INFILTRAÇÃO
}

\author{
LUCIANA GOMES CASTRO
}

Engenheira Agrônoma

Orientador: Prof. Dr. QUIRIJN DE JONG VAN LIER

Tese apresentada à Escola Superior de Agricultura "Luiz de Queiroz", Universidade de São Paulo, para obtenção do título de Doutor em Agronomia, Área de concentração: Solos e Nutrição de Plantas.

P I R A C I C A B A

Estado de São Paulo - Brasil

Outubro - 2001 
Dados Internacionais de Catalogação na Publicação (CIP) DIVISÃO DE BIBLIOTECA E DOCUMENTAÇÃO - ESALQ/USP

Castro, Luciana Gomes

Dinâmica da água em terraços de infiltração / Luciana Gomes Castro. - - Piracicaba, 2001.

104 p. : il.

Tese (doutorado) - Escola Superior de Agricultura Luiz de Queiroz, 2001.

Bibliografia.

1. Erosão 2. Física do solo 3. Infiltração 4. Manejo de solo 5. Modelo matemático 6. Terraceamento 7. Terraço I. Título

CDD 631.45

"Permitida a cópia total ou parcial deste documento, desde que citada a fonte - $\mathrm{O}$ autor" 
À sociedade! 


\section{AGRADECIMENTOS}

Ao meu mestre Prof. Dr. Quirijn de Jong van Lier, pelos ensinamentos e maneira com que estes foram transmitidos, principalmente, pela paciência, companheirismo e pelas sábias palavras de vida que me acompanharam ao longo desses anos;

Ao Prof. Dr. Paulo Leonel Libardi pelo auxílio na orientação, apoio e carinho;

Ao Prof. Dr. Gerd Sparovek pela grande colaboração na elaboração do projeto de Tese, na implantação do experimento e auxílio na finalização do trabalho;

Ao conselho do curso de pós-graduação em Solos e Nutrição de Plantas da ESALQ/USP pela oportunidade de realização do curso;

Ao Prof. Dr. Sérgio Oliveira Moraes pelos conselhos, paciência, auxílio e pelas palavras de conforto e estímulo, principalmente, nas horas mais difíceis;

Ao Prof. Dr. Nilson Villa Nova pela grande e eterna amizade;

Ao Prof. Dr. Álvaro Pires da Silva pela concessão de uso do Laboratório de Física do Solo do Dept ${ }^{\circ}$. de Solos e Nutrição de Plantas onde algumas análises foram realizadas;

Ao CNPq, Conselho de Desenvolvimento Cientifico e Tecnológico, pela bolsa de estudos concedida;

À FAPESP pelo auxílio financeiro ao desenvolvimento do Projeto;

Ao Prof. Dr. Marcos Vinícios Follegati, prefeito do Campus da ESALQ, pela amizade e colaborações prestadas ao longo da condução do experimento;

Aos funcionários Luiz Fernando Novello e Francisco Bernardo Dias do Dept ${ }^{\circ}$. de Ciências Exatas pelo apoio em todas as etapas deste trabalho; 
Aos funcionários do Dept $^{\circ}$. de Agricultura pela importante colaboração na implantação e condução do experimento, em especial, ao Tanaka, Italiano e Bisteca pelo empenho e amizade conquistada;

Aos funcionários Hélio, Gilmar e Jesuíno do Dept ${ }^{\circ}$. de Engenharia Rural;

Aos amigos Adilson, Jeane, Jean, José Fernandes, José Ronaldo, Enio, Evandro, Marcelo, Timm, Alaílson, Toninho e Claudia pela amizade, consideração e cooperação mútua para que esta Tese pudesse ser realizada;

Aos demais amigos e colegas da pós-graduação da ESALQ/USP pelo convívio;

A todos que direta ou indiretamente colaboraram para a realização deste trabalho, sinceramente agradeço;

À minha família e ao meu namorado, companheiros de todas as horas, por tudo!

Obrigada a todos! 


\section{SUMÁRIO}

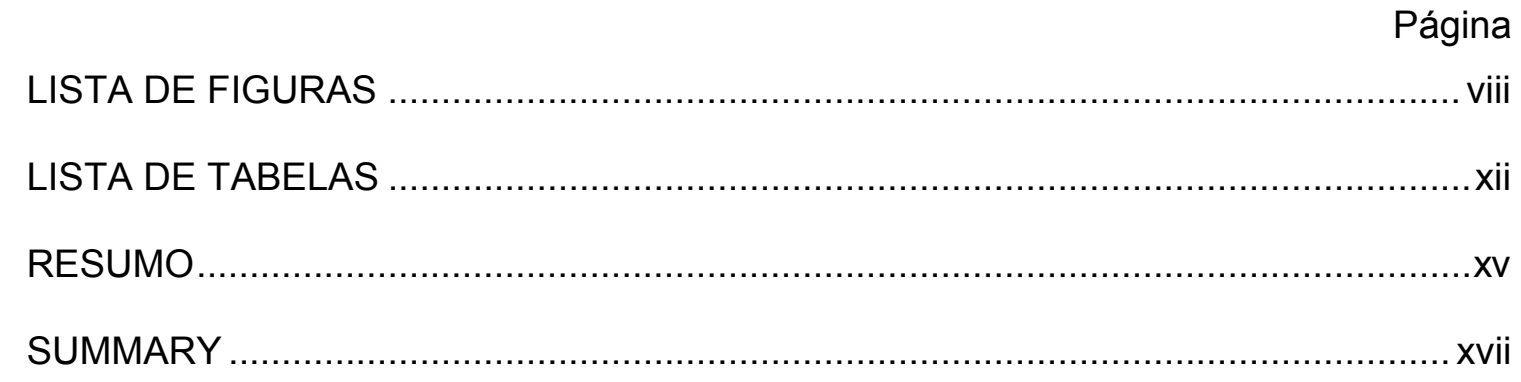

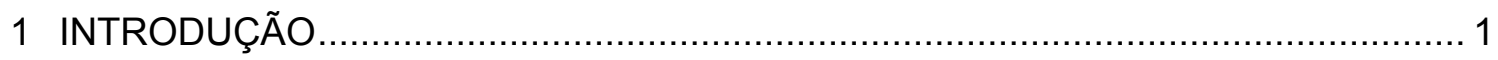

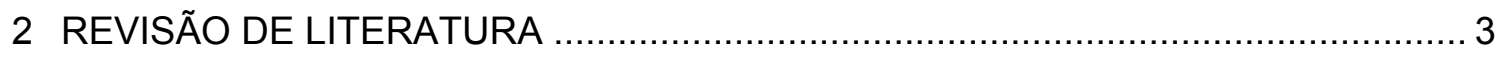

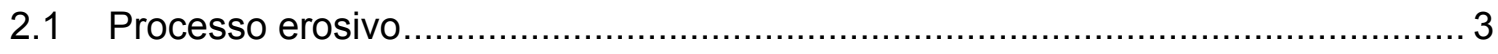

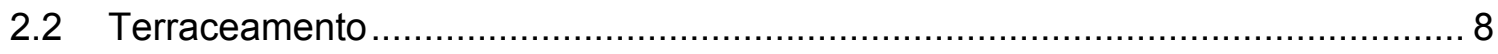

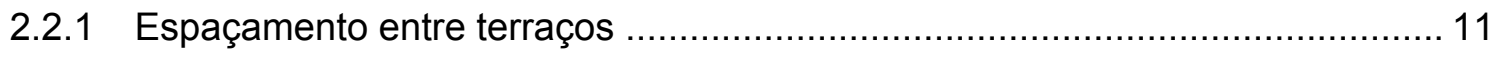

2.2.2 Dimensionamento do canal do terraço ................................................... 13

2.3 Infiltração sob condições de selamento superficial .......................................... 15

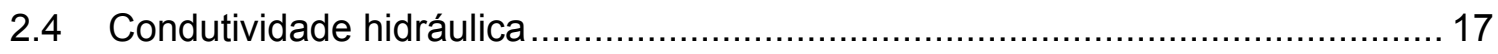

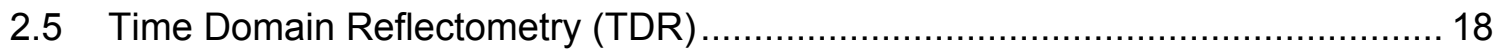

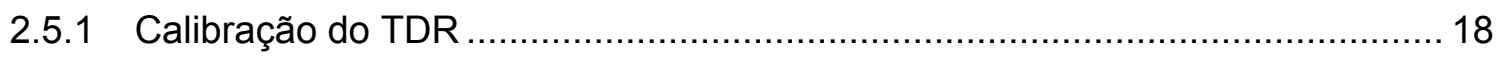

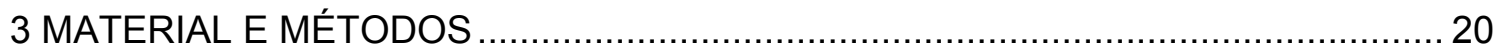

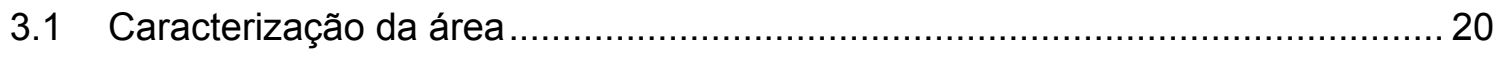

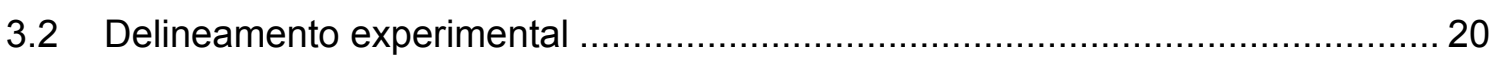

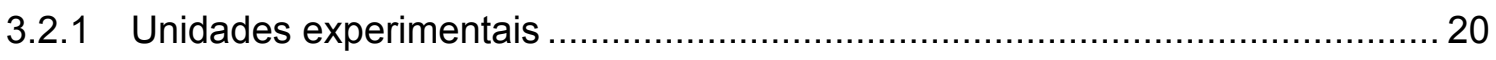

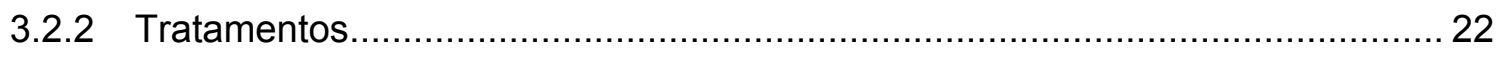

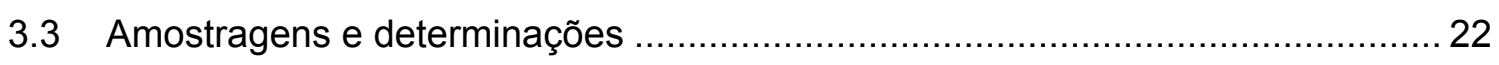

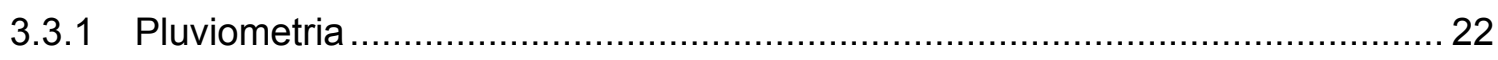

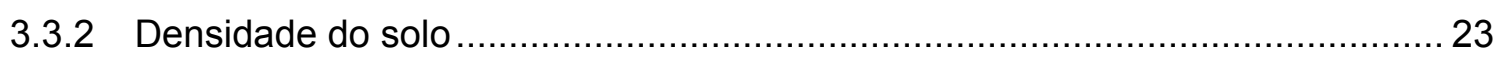

3.3.3 Curva de retenção de água no solo.................................................... 24

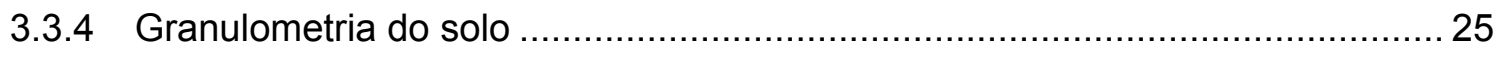




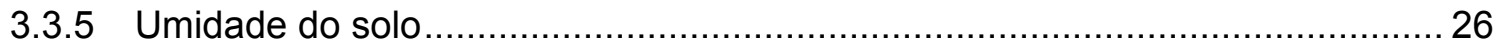

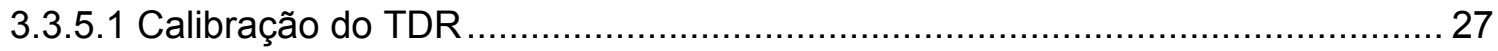

3.3.6 Condutividade hidráulica do solo não saturado .......................................... 28

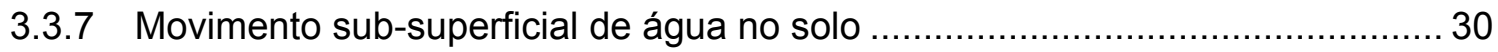

3.3.8 Estimativa do acúmulo de deposição de solo no canal ................................... 32

3.3.9 Armazenagem de água no solo do canal do terraço ...................................... 33

3.3.10 Taxa de infiltração de água no canal e na área a montante após chuvas ........ 33

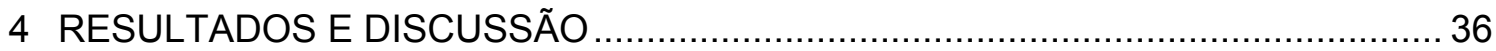

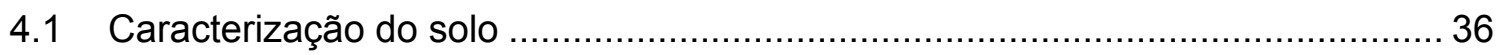

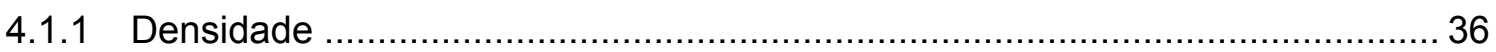

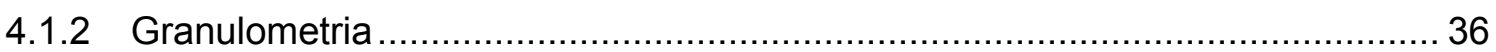

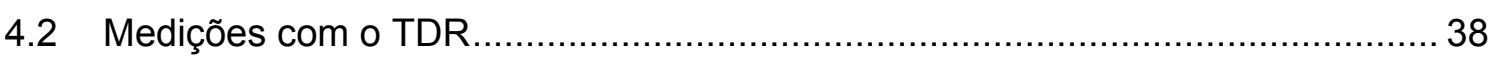

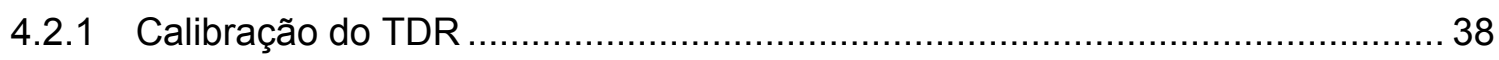

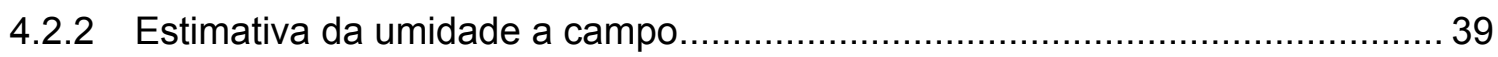

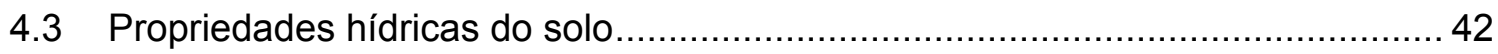

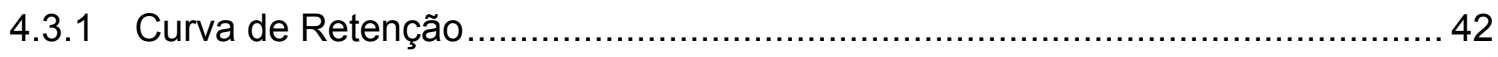

4.3.2 Condutividade hidráulica do solo não saturado ......................................... 45

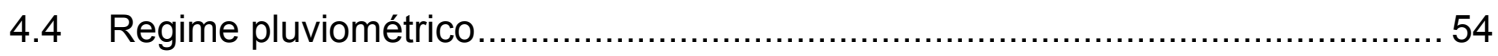

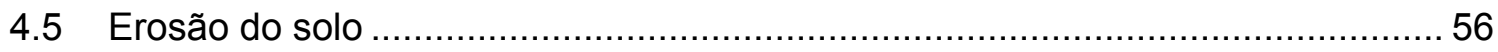

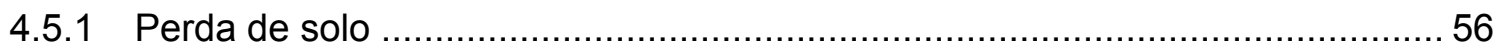

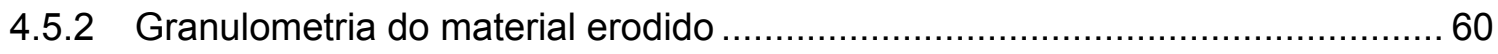

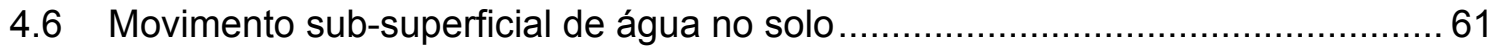

4.7 Armazenagem de água no solo do canal do terraço ......................................... 72

4.7.1 Março de $2000-1^{\circ}$ ano de cultivo ......................................................... 72

4.7.2 Dezembro de $2000-2^{\circ}$ ano de cultivo......................................................

4.8 Taxa de infiltração de água no solo ............................................................ 81

4.8.1 Taxa de infiltração desconsiderando fluxo na profundidade de $0,90 \mathrm{~m}$........... 81

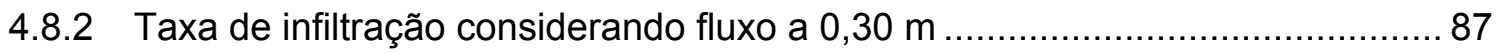

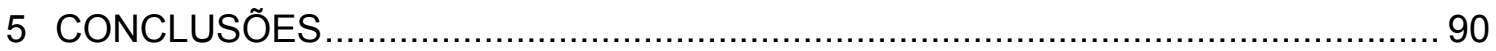

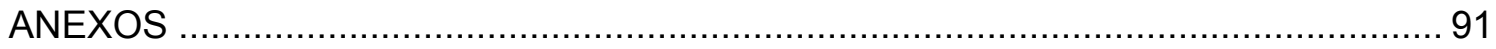

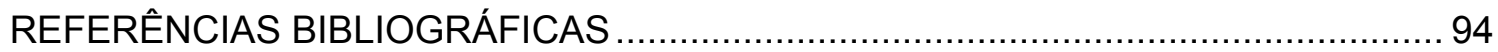




\section{LISTA DE FIGURAS}

Página

1 Mapa da área experimental mostrando as isolinhas das cotas do terreno, as quatro parcelas, os 12 locais de amostragem e observação no canal do terraço (três por parcela) e a localização do equipamento TDR.

2 Localização do pluviômetro na área experimental (a) e detalhe interno do equipamento (b).

3 Caixas de areia (a) e câmaras de pressão (b) para a determinação da curva de retenção de água no solo.

4 TDR modelo TRASE-BE e guia de onda Para medida de umidade do solo.

5 Terraço coberto por lona plástica para a medição da condutividade hidráulica do solo em função de sua umidade.

6 Pontos de observação (estacas brancas, no centro do canal) para o monitoramento da perda de solo no canal do terraço da parcela plantio direto.... 32

7 Valores de $\mathrm{K}_{\mathrm{a}}$ em função de $\theta$ (pontos) para as profundidades $5 \mathrm{~cm}, 10 \mathrm{~cm}$, $20 \mathrm{~cm}, 40 \mathrm{~cm}, 60 \mathrm{~cm}$ e $80 \mathrm{~cm}$, conforme legenda, bem como a eq. 8 ajustada (linha sólida).

8 Valores de $\theta$ estimados pela eq. 8, para cada ponto de observação (repetição) e profundidade em estudo, correspondentes às 2 horas do dia 29 de março de 2000.

9 Curvas de retenção de água no solo no tratamento preparo convencional, referentes às três repetições da profundidade de $40 \mathrm{~cm}$. 
10 Condutividade hidráulica em função da umidade do solo, para cada repetição e profundidade $(5 \mathrm{~cm}, 10 \mathrm{~cm}, 20 \mathrm{~cm}, 40 \mathrm{~cm}, 60 \mathrm{~cm}$ e $80 \mathrm{~cm})$, na faixa de determinação e suas médias logarítmicas nos tratamentos grama e plantio direto.

11 Condutividade hidráulica em função da umidade do solo, para cada repetição e profundidade $(5 \mathrm{~cm}, 10 \mathrm{~cm}, 20 \mathrm{~cm}, 40 \mathrm{~cm}, 60 \mathrm{~cm}$ e $80 \mathrm{~cm})$, na faixa de determinação e suas médias logarítmicas nos tratamentos preparo convencional e solo nu.

12 Lâmina de chuva acumulada (mm) nos meses de fevereiro a abril de 2000, correspondente ao $1^{\circ}$ período de condução do experimento.

13 Lâmina de chuva acumulada ( $\mathrm{mm}$ ) nos meses de dezembro de 2000 e janeiro de 2001 , correspondente ao $2^{\circ}$ período de condução do experimento.

14 Deposição acumulada de solo $(\mathrm{cm})$ a partir de fev/2000 para o mês de março (primeiro ano de cultivo de milho) nos tratamentos grama, plantio direto, preparo convencional e solo nu, bem como a chuva acumulada no mês.

15 Deposição de material erodido sobre o canal do terraço do preparo convencional após o aparecimento de um sulco.

16 Deposição acumulada de solo $(\mathrm{cm})$ a partir de fev/2000 para o mês de dezembro (segundo ano de cultivo de milho) nos tratamentos grama, plantio direto e preparo convencional, bem como a chuva acumulada no mês.

17 Deposição acumulada de solo $(\mathrm{cm})$ a partir de fev/2000 para o mês de dezembro (segundo ano de cultivo de milho) no tratamento solo nu, bem como a chuva acumulada no mês.

18 Deposição de solo sobre o canal do terraço do tratamento solo nu (a) com detalhe da estratificação (b).

19 Média diária da densidade de fluxo de água no solo ( $\mathrm{q}, \mathrm{mm} \mathrm{h}^{-1}$ ) nos tratamentos grama, plantio direto, preparo convencional e solo nu, para as camadas de 5 a $10 \mathrm{~cm}, 10$ a $20 \mathrm{~cm}, 20$ a $40 \mathrm{~cm}, 40$ a $60 \mathrm{~cm}$ e de 60 a $80 \mathrm{~cm}$ e chuva acumulada no mês de fevereiro de 2000 . 
20 Média diária da densidade de fluxo de água no solo (q, $\mathrm{mm} \mathrm{h}^{-1}$ ) nos tratamentos grama, plantio direto, preparo convencional e solo nu, para as camadas de 5 a $10 \mathrm{~cm}, 10$ a $20 \mathrm{~cm}, 20$ a $40 \mathrm{~cm}, 40$ a $60 \mathrm{~cm}$ e de 60 a $80 \mathrm{~cm}$ e chuva acumulada no mês de março de 2000.

21 Média diária da densidade de fluxo de água no solo ( $\mathrm{q}, \mathrm{mm} \mathrm{h}^{-1}$ ) nos tratamentos grama, plantio direto, preparo convencional e solo nu, para as camadas de 5 a $10 \mathrm{~cm}, 10$ a $20 \mathrm{~cm}, 20$ a $40 \mathrm{~cm}, 40$ a $60 \mathrm{~cm}$ e de 60 a $80 \mathrm{~cm}$ e chuva acumulada no mês de abril de 2000 .

22 Densidade de fluxo de água no solo (q, $\mathrm{mm} \mathrm{h}^{-1}$, valores de $30 \mathrm{em} 30 \mathrm{~min}$ ) nos tratamentos grama, plantio direto, preparo convencional e solo nu, para as camadas de 5 a $10 \mathrm{~cm}, 10$ a $20 \mathrm{~cm}, 20$ a $40 \mathrm{~cm}, 40$ a $60 \mathrm{~cm}$ e de 60 a $80 \mathrm{~cm}$ e chuva acumulada no período de 27 de março a 4 de abril de 2000 .

23 Média diária da densidade de fluxo de água no solo ( $\mathrm{q}, \mathrm{mm} \mathrm{h}^{-1}$ ) nos tratamentos grama, plantio direto, preparo convencional e solo nu, para as camadas de 5 a $10 \mathrm{~cm}, 10$ a $20 \mathrm{~cm}, 20$ a $40 \mathrm{~cm}, 40$ a $60 \mathrm{~cm}$ e de 60 a $80 \mathrm{~cm}$ e chuva acumulada no mês de dezembro de 2000 .

24 Média diária da densidade de fluxo de água no solo (q, $\mathrm{mm} \mathrm{h}^{-1}$ ) nos tratamentos grama, plantio direto, preparo convencional e solo nu, para as camadas de 5 a $10 \mathrm{~cm}, 10$ a $20 \mathrm{~cm}, 20$ a $40 \mathrm{~cm}, 40$ a $60 \mathrm{~cm}$ e de 60 a $80 \mathrm{~cm}$ e chuva acumulada no mês de janeiro de 2001.

25 Armazenagem de água no perfil de solo entre a superfície original e a profundidade $0,9 \mathrm{~m}(\mathrm{~h}, \mathrm{~mm})$, nos tratamentos grama, plantio direto, preparo convencional e solo nu e a chuva acumulada no mês de março de 2000.

26 Armazenagem de água no perfil de solo considerando a camada de deposição sobre a superfície do canal $(\mathrm{h}, \mathrm{mm})$, nos tratamentos grama, plantio direto, preparo convencional e solo nu e a chuva acumulada no mês de março de 2000.

27 Distribuição da água sobre o canal do terraço do tratamento solo nu, após o término de uma chuva, e a incidência de um maior acúmulo sobre uma das repetições. 
28 Armazenagem de água no perfil de solo entre a superfície original e a profundidade $0,9 \mathrm{~m}(\mathrm{~h}, \mathrm{~mm})$, nos tratamentos grama, plantio direto, preparo convencional e solo nu e a chuva acumulada no mês de dezembro de $2000 \ldots . . .78$

29 Armazenagem de água no perfil de solo considerando a camada de deposição sobre a superfície do canal $(\mathrm{h}, \mathrm{mm})$, nos tratamentos grama, plantio direto, preparo convencional e solo nu e a chuva acumulada no mês de dezembro de 2000.

30 Taxa de chuva e de infiltração da água no terraço e na área a montante do terraço nos dias 07/03/00, 26/03/00 e 28/03/00 para os tratamentos grama, plantio direto, preparo convencional e solo nu, considerando a armazenagem até a profundidade $0,90 \mathrm{~m}$ e a ausência de fluxo abaixo desta.

31 Taxa de chuva e de infiltração da água no terraço e na área a montante do terraço nos dias $04 / 12 / 00,16 / 12 / 00$ e 27/12/00 para os tratamentos grama, plantio direto, preparo convencional e solo nu, considerando a armazenagem até a profundidade $0,90 \mathrm{~m}$ e a ausência de fluxo abaixo desta.

32 Taxa de chuva e de infiltração da água no terraço e na área a montante do terraço nos dias $07 / 03 / 00,26 / 03 / 00$ e 28/03/00 para os tratamentos grama, plantio direto, preparo convencional e solo nu, considerando a armazenagem até a profundidade $0,30 \mathrm{~m}$ e a presença de fluxo abaixo desta.

33 Taxa de chuva e de infiltração da água no terraço e na área a montante do terraço nos dias 04/12/00, 16/12/00 e 27/12/00 para os tratamentos grama, plantio direto, preparo convencional e solo nu, considerando a armazenagem até a profundidade $0,30 \mathrm{~m}$ e a presença de fluxo abaixo desta. 


\section{LISTA DE TABELAS}

Página

1 Densidade do solo $\left(\mathrm{kg} \mathrm{m}^{-3}\right)$ nos tratamentos e profundidades em estudo (média de três repetições). 36

2 Granulometria do solo no canal do terraço nos tratamentos grama ( $\mathrm{Gr}$ ), plantio direto $(P D)$, preparo convencional $(P C)$ e solo nu $(S N)$ nas profundidades em estudo.

3 Parâmetros de ajuste da calibração da umidade do solo em função da constante dielétrica para todas as profundidades e o intervalo de confiança dos coeficientes de ajuste.

4 Coeficiente de variação médio para os valores de Ka $(\overline{C V})$ no mês de março/2000 e o coeficiente de variação dos coeficientes de variação $\left(C V_{C V}\right)$, para cada profundidade e tratamento em estudo.

5 Parâmetros de ajuste do modelo de van Genuchten para a descrição das curvas de retenção de água no solo no tratamento grama.

6 Parâmetros de ajuste do modelo de van Genuchten para a descrição das curvas de retenção de água no solo no tratamento plantio direto.

7 Parâmetros de ajuste do modelo de van Genuchten para a descrição das curvas de retenção de água no solo no tratamento preparo convencional.

8 Parâmetros de ajuste do modelo de van Genuchten para a descrição das curvas de retenção de água no solo no tratamento solo nu. 
9 Parâmetros de ajuste do modelo de condutividade hidráulica do solo não saturado para as profundidades em estudo nas três repetições e médias no tratamento grama e os intervalos de umidade e de $\mathrm{K}(\theta)$ ocorridos no experimento, bem como o coeficiente de correlação obtido em cada equação de ajuste.

10 Parâmetros de ajuste do modelo de condutividade hidráulica do solo não saturado para as profundidades em estudo nas três repetições e médias no tratamento plantio direto e os intervalos de umidade e de $K(\theta)$ ocorridos no experimento, bem como o coeficiente de correlação obtido em cada equação de ajuste.

11 Parâmetros de ajuste do modelo de condutividade hidráulica do solo não saturado para as profundidades em estudo nas três repetições e médias no tratamento preparo convencional e os intervalos de umidade e de $K(\theta)$ ocorridos no experimento, bem como o coeficiente de correlação obtido em cada equação de ajuste.

12 Parâmetros de ajuste do modelo de condutividade hidráulica do solo não saturado para as profundidades em estudo nas três repetições e médias no tratamento solo nu e os intervalos de umidade e de $K(\theta)$ ocorridos no experimento, bem como o coeficiente de correlação obtido em cada equação de ajuste.

13 Parâmetros de ajuste da equação de condutividade hidráulica em função da umidade do solo (eq. 13), utilizando todos os pares de dados de $\mathrm{K}$ e $\theta$ obtidos em cada profundidade nas três repetições, bem como o coeficiente de correlação obtido em cada equação de ajuste, para os tratamentos grama, plantio direto, preparo convencional e solo nu

14 Granulometria média da superfície do solo nos tratamentos grama, plantio direto, preparo convencional e solo nu e do material depositado sobre o canal do terraço (média de cinco repetições).

15 Características das chuvas e duração das armazenagens de água no canal e na área a montante do canal. 
16 Fração de água da chuva infiltrada no canal do terraço $\left(f_{t}, m^{3} m^{-3}\right)$ e na área a montante $\left(f_{a}, \mathrm{~m}^{3} \mathrm{~m}^{-3}\right)$, desconsiderando a presença de fluxo abaixo de $0,90 \mathrm{~m}$

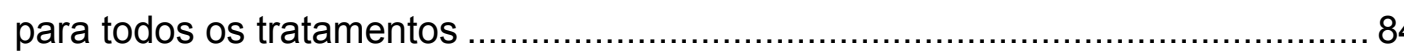

17 Fração de água da chuva infiltrada no canal do terraço $\left(f_{t}, m^{3} m^{-3}\right)$ e na área a montante $\left(f_{a}, \mathrm{~m}^{3} \mathrm{~m}^{-3}\right)$, considerando a presença de fluxo abaixo de 0,30 m para todos os tratamentos. 


\title{
DINÂMICA DA ÁGUA EM TERRAÇOS DE INFILTRAÇÃO
}

\author{
Autora: LUCIANA GOMES CASTRO \\ Orientador:Prof. Dr. QUIRIJN DE JONG VAN LIER
}

\section{RESUMO}

O terraceamento é uma prática de conservação do solo que visa reduzir a perda de água e solo pela interceptação de enxurradas que ocorrem quando a intensidade da chuva supera a capacidade de infiltração de água no solo. Atualmente, o dimensionamento dos terraços tem sido feito com base em conhecimento empírico; no entanto, um conhecimento mais detalhado da física dos processos que regem o funcionamento dos terraços possibilitaria otimizar o dimensionamento dos terraços. No presente estudo foi avaliada a capacidade de infiltração de água no canal de um terraço em nível pelos métodos da densidade de fluxo e da armazenagem de água em diferentes condições de manejo agrícola (solo nu, solo gramado e solo sob preparo convencional e plantio direto para a implantação da cultura de milho) num Latossolo vermelho com declividade média de $0,08 \mathrm{~m} \mathrm{~m}^{-1}$. Em cada tratamento foram instaladas sondas de TDR em três pontos de observação no centro do canal do terraço (distanciados de $4 \mathrm{~m}$ entre si e considerados como repetições), nas profundidades de $0,05,0,10,0,20,0,40,0,60$ e $0,80 \mathrm{~m}$. Nestas mesmas profundidades amostras indeformadas de solo foram retiradas para determinação da densidade e curva de retenção de água no solo. As leituras das guias de onda do TDR foram feitas automaticamente e a intensidade de chuva monitorada por um pluviômetro 
automatizado. Ao final de cada evento de chuva erosiva a deposição de solo foi medida por meio de 14 pontos de observação dispostos ao longo do centro do canal do terraço de cada tratamento. Durante a estação seca (julho-agosto), a condutividade hidráulica do solo não saturado foi determinada em cada repetição nas mesmas profundidades, utilizando o método do perfil instantâneo. Os resultados demonstraram que os manejos agrícolas influenciam na deposição de água e solo sobre o canal do terraço e estas na formação de selo superficial e na capacidade de infiltração de água do canal. Conclui-se que a alta variação comumente obtida entre as repetições de determinação da condutividade hidráulica implica em dificuldades quando se objetiva detectar pequenas diferenças nas densidades de fluxo entre tratamentos. Assim, mostrou ser inviável utilizar densidades de fluxo calculadas pela equação de DarcyBuckingham para encontrar diferenças em taxas de infiltração em terraços em nível. Essa conclusão reforça-se devido às condições superficiais altamente variáveis encontradas em canais de terraços em nível devido a deposições irregulares do material erodido. Uma metodologia para se realizar medições da umidade nas deposições sobre o canal deve ser desenvolvida para aumentar a acurácia da medida da armazenagem. A taxa de infiltração de água no canal do terraço não pode ser estimada pela variação da armazenagem da água no solo somente, devido ao papel importante da drenagem profunda e, possivelmente, da absorção de água pela camalhão do terraço. Uma adequada estimativa da taxa de infiltração no canal do terraço, imprescindível para seu dimensionamento, deve aliar um grande número de repetições, além da medição da umidade no interior da camada de material depositado sobre o canal ao longo do tempo. 


\title{
WATER DYNAMICS IN LEVEL TERRACES
}

\author{
Author: LUCIANA GOMES CASTRO \\ Adviser: Prof. Dr. QUIRIJN DE JONG VAN LIER
}

\section{SUMMARY}

Terracing is a soil conservation practice that aims to reduce water and soil loss by interception of runoff that occurs when rainfall intensities exceed infiltration capacity. Actually, dimensions of terraces are being determined in an empirical way; however, a more detailed understanding of the physics behind the hydrological functions of terraces would allow an optimized dimensioning of terraces. In this study the infiltration capacity of a level terrace was evaluated by the methods of flux density and water storage, under different management conditions (bare soil, pasture, conventionally tilled maize and zero-tillage maize) on an oxisol with a slope of $0.08 \mathrm{~m} \mathrm{~m}^{-1}$. In each treatment TDR sensors were installed at three observation points in the middle of the terrace canal (distance between points: $4 \mathrm{~m}$; considered to be repetitions) at the depths of 0.05 , $0.10,0.20,0.40,0.60$ and $0.80 \mathrm{~m}$. At the same depths, undisturbed soil samples were taken to determine soil density and soil water retention curve. TDR readings were made automatically and a rainfall gauge automatically monitored rainfall intensity. At the end of each rainfall event, soil deposition was measured at 14 locations in the terrace canal in each treatment. During the dry season (July-August), unsaturated hydraulic conductivity was determined at each repetition at the same depths by the instantaneous profile method. The results showed that agricultural management influenced water and 
soil deposition in the terrace canal and these affected surfaced sealing and infiltration capacity. It was concluded that the high variation usually obtained between repetitions of the hydraulic conductivity determinations makes the detection of small differences between flux densities difficult. Therefore, it showed to be impossible to use flux densities calculated by Darcy-Buckingham equation in the order to prove existence of different infiltration rates in level terraces. This conclusion was reinforced due to the highly variable surface conditions in the terrace canal. A methodology to measure water contents within the depositions in the canal should be developed to increase the precision of water storage estimation. Infiltration rates in the terrace canal cannot be estimated by storage variation alone, due to the important role of drainage and, possibly, ascension of water in the terrace hill. A correct estimate of the infiltration rate in the canal, necessary for its dimensioning, should combine a high number of repetitions with the measurement of water content within the layer of deposits over the terrace canal surface along time. 


\section{INTRODUÇÃO}

A erosão acelerada é um dos grandes problemas para a agricultura intensiva cotidiana. Com a pressão populacional, áreas antes consideradas marginais por causa de sua declividade ou tipo de solo estão sendo desmatadas e ocupadas, principalmente por culturas anuais, reduzindo assim a cobertura vegetal permanente, interferindo negativamente no equilíbrio ecológico da estrutura do solo, diminuindo sua resistência às forças erosivas.

Entretanto, a erosão hídrica pode ser reduzida por um manejo adequado dos restos culturais, principalmente, devido à manutenção de cobertura vegetal pelos resíduos sobre a superfície do solo. No entanto, nem sempre o manejo cultural é suficiente para a redução da erosão em um ecossistema sustentável. Nesses casos, é preciso utilizar-se de práticas mecânicas de controle da erosão, cujo exemplo mais conhecido é o terraceamento agrícola.

O terraceamento é uma prática de conservação do solo que visa reduzir a perda de água e solo pela interceptação de enxurradas que ocorrem quando a intensidade da chuva supera a capacidade de infiltração de água no solo. Atualmente, o dimensionamento dos terraços tem sido feito com base em conhecimento empírico; no entanto, um conhecimento mais detalhado da física dos processos que regem o funcionamento dos terraços possibilitaria otimizar o dimensionamento dos terraços, levando em consideração as conseqüências econômicas pois terraços superdimensionados resultam em custos desnecessários, enquanto os subdimensionados podem não exercer sua função, rompendo-se e levando a prejuízos ainda maiores do que se não estivessem construídos.

A capacidade de infiltração tem um papel essencial no funcionamento hidrológico dos terraços. Quanto mais água infiltra no solo, menos enxurrada é formada e quanto maior a capacidade de infiltração no canal do terraço, maior a sua 
capacidade de absorver uma enxurrada e menores podem ser suas dimensões. Como a taxa de infiltração é altamente variável ao longo da vida útil de um terraço devido à deposição irregular de material, torna-se muito difícil a determinação dessa. Os métodos convencionais de medição das taxas de infiltração normalmente fazem necessárias algumas perturbações da superfície do solo e do selo, alterando as condições superficiais e reduzindo a validade das observações.

Foi o objetivo da presente Tese estudar a dinâmica da água em terraços de infiltração, visando levar subsídios para a estimativa da capacidade de infiltração no canal do terraço e sua variação no tempo, que é influenciada pelo manejo. 


\section{REVISÃO DE LITERATURA}

\subsection{Processo erosivo}

O processo de erosão do solo é constituído de três fases distintas: desagregação, transporte e deposição. A erosão hídrica inicia na desagregação dos agregados de solo causada, principalmente, pela ação da energia cinética das gotas da chuva mas também pela ação da energia cinética do escoamento superficial, denominado de enxurrada, quando presente. Logo após a desagregação ocorre o transporte, principalmente pela ação da enxurrada. Neste caso, a ação de salpico, impacto das gotas da chuva sobre o solo, é pequena. A deposição do material erodido, terceira e última fase do processo erosivo, ocorre somente quando a carga de sedimentos excede a sua capacidade de transporte, concluindo o processo erosivo. $O$ processo é considerado seletivo pois as primeiras partículas de solo a serem depositadas são as de menor carga e, assim, sucessivamente (Ellison, 1947).

As perdas de solo por erosão hídrica sofrem influência de fatores relacionados à chuva (erosividade), ao solo (erodibilidade), à topografia (comprimento e grau de declive) e ao manejo do solo (cobertura vegetal, preparo de solo, práticas conservacionistas de suporte) (Smith \& Wischmeier, 1962; Bertoni et al., 1975; Wischmeier \& Smith, 1978). Pela Equação Universal de Perda de Solo (EUPS), o produto da erosividade e erodibilidade equivale à máxima perda de solo e esta perda pode ser reduzida em função de fatores topográficos ou de manejo do solo.

A erosividade, uma propriedade da chuva, diz respeito à habilidade potencial dessa em causar erosão (Wischmeier \& Smith, 1978). Dentre as características das chuvas, as mais importantes são a intensidade, a duração e a freqüência pois influenciam diretamente no processo de erosão, através do desprendimento das partículas de solo pelo impacto das gotas da chuva (Lemos \& Bahia, 1992). Normalmente, chuvas de alta intensidade ocorrem em curtos intervalos de tempo, no 
entanto, a infreqüente combinação de chuvas de alta intensidade e de longa duração proporcionam o aparecimento de chuvas altamente erosivas (Morais et al., 1988; Eltz et al., 1992) pois quanto maior a intensidade, maior a energia cinética das gotas da chuva transferida à superfície do solo na ocasião do impacto; quanto maior a duração, menor a parte proporcional de água que infiltra, conseqüentemente, maiores as enxurradas (Morais et al., 1988). Por outro lado, chuvas de pequena duração causam muito pouca erosão pois, normalmente, não proporcionam o aparecimento de enxurradas. Quando chuvas de pequena duração estão aliadas a altas freqüências, o risco de erosão se torna altamente dependente da umidade inicial do solo no início da chuva, pois esta influi na capacidade de retenção de água pelas depressões e microdepressões do terreno, além de reduzir a taxa de infiltração de água, proporcionando aumento nos riscos de erosão (Duley, 1939; Trumam \& Bradford, 1990). Duley (1939) salienta que o impacto das gotas da chuva sobre o solo reduz rapidamente a sua capacidade de infiltração, principalmente em superfícies descobertas, devido à formação de uma fina camada de solo, composta por partículas de pequeno diâmetro, que reduz a porosidade e o fluxo de água nessa camada.

A erodibilidade, propriedade do solo que expressa a susceptibilidade desse à erosão, varia de acordo com o tipo de solo, cujas características influenciam na capacidade de retenção e de infiltração de água no solo determinando a quantidade e a taxa de enxurrada. Influenciam, também, na resistência do solo à desagregação de partículas e ao transporte pelas forças erosivas da chuva e da enxurrada determinando as perdas de solo e água (Lima et al., 1992). A erodibilidade estimada para alguns solos locais pode ser encontrada em Lombardi Neto \& Bertoni (1975) e em Freire \& Pessotti (1976). Esta pode ser estimada através do efeito conjunto de alguns atributos de cada solo como a textura, estrutura, matéria orgânica e a permeabilidade (Wischmeier \& Mannering, 1969; Wischmeier et al., 1971; Lombardi Neto \& Bertoni, 1975; Wischmeier \& Smith, 1978).

Para reduzir a ação desagregadora do impacto das gotas da chuva e da ação da enxurrada sobre o solo e reduzir a perda por erosão, empregam-se as práticas conservacionistas. A manutenção da cobertura vegetal sobre o solo, isoladamente, é o fator de maior importância relativa no controle da erosão hídrica. A utilização de resíduos culturais como cobertura do solo é uma maneira simples, eficaz e econômica 
de se controlar a erosão sobre as terras agrícolas, contudo, depende de fatores como o tipo, a quantidade e a porcentagem de cobertura do solo, forma de manejo, maneira de distribuição e estágio de decomposição dos resíduos no solo (Lopes et al., 1987a, b). Estes, quando mantidos sobre a superfície do solo, evitam o impacto direto das gotas da chuva, prevenindo a desagregação e o selamento superficial, proporcionando assim uma menor redução das taxas de infiltração de água no solo. Além disso, reduzem acentuadamente a velocidade do escoamento superficial, diminuindo a capacidade de desagregação e transporte pela enxurrada (Wischmeier, 1973; Cogo, 1981; Lopes et al., 1987a, b).

A forma de preparo do solo é outro fator muito importante no manejo pois dela depende, em grande parte, o destino dos restos culturais, a rugosidade superficial do solo, a porosidade total da camada preparada, o encrostamento superficial, a capacidade de retenção de água no solo, além da distribuição e do comportamento dos nutrientes na camada explorada pelas raízes, entre outras coisas. O aumento no número de operações de preparo do solo, principalmente, o uso de equipamentos de preparo secundário, tende a diminuir a rugosidade superficial e a porosidade total da camada preparada, diminuindo a estabilidade dos agregados e a quantidade de solo prontamente disponível para o transporte, facilitando a ação da enxurrada e as perdas de solo e água (Burwell et al., 1963 e 1966; Allmaras et al., 1966 e 1967; Cogo, 1981). O aumento na intensidade de preparo também reduz a porcentagem de cobertura do solo pela incorporação parcial ou total dos resíduos culturais preexistentes, deixando o solo exposto à ação desagregadora da energia cinética de impacto das gotas da chuva, favorecendo ainda mais a erosão hídrica (Wischmeier, 1973; Cogo, 1981). Preparos que visam manter a rugosidade superficial, principalmente a rugosidade ao acaso, formada pela ocorrência irregular de picos e depressões deixados no solo após o preparo (Burwell et al., 1966) auxiliam na redução das perdas de solo pois aumentam a capacidade de armazenamento superficial de água pelo aumento da retenção superficial, reduzindo a quantidade e velocidade da enxurrada e, conseqüentemente, a capacidade de desagregação e transporte das partículas de solo em suspensão na enxurrada, auxiliando na deposição do material suspenso quando em contato com as barreiras físicas formadas pelos picos e depressões da superfície do terreno (Burwell et al., 1966; Allmaras et al., 1966 e1967; Castro, 1998). 
O preparo do solo pode ser realizado de diversas formas, no entanto, geralmente classifica-se o preparo como "convencional" ou "conservacionista". Dentre os preparos conservacionistas mais utilizados encontram-se a semeadura direta, mais comumente conhecida por plantio direto, e a escarificação, sendo a semeadura direta encontrada com maior freqüência devido ao menor número de operações de preparo envolvidos e a maior cobertura vegetal presente superficialmente. Os preparos conservacionistas visam, principalmente, a manutenção parcial ou total dos resíduos vegetais a fim de reduzir o impacto direto das gotas da chuva sobre o solo e assim a erosão, já os preparos convencionais, caracterizados pela ação de preparo primário do solo através de uma aração seguida de preparo secundário por meio de duas gradagens pesadas, incorporam grande parte dos resíduos e desestruturam a camada superficial do solo, facilitando a ocorrência de erosão. Apesar disso, o preparo convencional ainda é bastante utilizado, principalmente, por motivos de resistência cultural.

A semeadura direta caracteriza-se, entre outros aspectos, pela preservação de grande parte dos restos culturais, apresentação de baixos índices de rugosidade superficial do solo, além da consolidação da superfície através da quase ausência de revolvimento do solo. Ao longo do tempo, essas características são acentuadas, principalmente quanto ao acúmulo de resíduos culturais na superfície, ocasionando uma gradativa e benéfica melhoria da estrutura do solo e resistência da superfície à ação da energia cinética das gotas da chuva e enxurrada. Por sua vez, faz-se necessário uma maior energia cisalhante do escoamento superficial para a remoção dos resíduos e o sulcamento do solo, em relação aos demais manejos (Bertol et al., 1987).

A escarificação, caracterizada pela baixa alteração na estrutura do solo e pela redução na incorporação de resíduos vegetais, também diminui a erodibilidade, mas a chuva ainda necessita de uma alta energia cisalhante para que ocorra a remoção de resíduos e/ou sulcamento do solo, principalmente devido à resistência de sua superfície proporcionada pela presença da rugosidade superficial do solo, deposição e ancoramento parcial de resíduos sobre sua superfície (Swanson et al., 1965; Bertol et al., 1987). As alterações na estrutura do solo proporcionadas por este tipo de preparo, entre outros, visam melhorar as suas condições para a infiltração e armazenamento de 
água e ar, principalmente, através do aumento da porosidade. As condições físicas da superfície também são alteradas, notadamente a rugosidade superficial e a quantidade de resíduos remanescentes.

A topografia, caracterizada pelo comprimento e grau de declive e pela forma da paisagem, pode alterar a erosão pois a velocidade do escoamento superficial, resultante do comprimento e grau de declive, determina o tamanho e a quantidade do material em suspensão (Hudson, 1995). Isoladamente, o grau de declive é um componente de grande importância na topografia, determinando a velocidade do escoamento superficial e, por sua vez, a quantidade do material em suspensão (Bertoni, 1959). Contudo, o comprimento de rampa não é menos importante que o declive pois é responsável por um maior ou menor aumento da área de captação de água da chuva. À medida que há um aumento no caminho percorrido pela água, o volume e a velocidade da enxurrada também aumentam. A forma com que a paisagem se apresenta no terreno também deve ser levada em consideração devido ao comportamento diferenciado de rampas côncavas, convexas ou mistas em relação ao processo erosivo (Wischmeier \& Smith, 1978). No entanto, a avaliação da forma da paisagem é normalmente negligenciada pela sua natureza complexa. Infere-se que declives côncavos permitem, inicialmente, uma erosão acelerada pelo declínio acentuado, com redução gradativa até que ocorra a deposição nas porções mais inferiores do declive. Ao contrário, nas paisagens de conformações convexas, o processo é gradativamente acelerado ao longo do lançante pelo aumento gradativo da declividade.

Quando a erosão se apresenta acima do tolerável mesmo com a utilização de preparo conservacionista e de manejo adequado dos resíduos culturais, pode-se recorrer a práticas conservacionistas de suporte, também denominadas de práticas mecânicas de controle da erosão. As mais freqüentemente utilizadas são o preparo e plantio em contorno, a implantação de cordões de vegetação permanente e o terraceamento. Essas se caracterizam por servirem de obstáculos mecânicos ao livre escoamento da enxurrada e são comumente adotadas na presença de elevados comprimentos e grau de declive. A prática de terraceamento é o tema central dessa Tese e, portanto, detalhada a seguir. 


\subsection{Terraceamento}

Dentre as práticas conservacionistas de suporte de caráter mecânico, que têm por objetivo servir de obstáculo ao livre escoamento da água, apresenta-se o terraceamento (Bertoni \& Lombardi Neto, 1990). Essa técnica visa reduzir o volume e a velocidade da enxurrada pela interrupção do comprimento de rampa através da presença de obstáculos mecânicos denominados de terraços, induzindo a deposição de água e solo, transportados pela enxurrada, sobre o canal.

A declividade do terreno determina a praticabilidade do terraceamento, uma vez que o aumento no volume e na velocidade da enxurrada são agravados com o comprimento e grau de declive. À medida que o declive é acentuado, o comprimento de rampa deve ser segmentado a curtas distâncias para que o escoamento superficial não atinja velocidades elevadas. No caso de declives bastante acentuados, torna-se impraticável a implantação de terraços pela grande redução da área cultivada aliada à dificuldade no manejo da cultura, além do aumento nos custos de construção e manutenção dos terraços. Outra restrição do uso de terraços ocorre em solos rasos, pedregosos e de drenagem limitada devido à grande dificuldade da sua construção e manutenção, levando ao encarecimento dos custos de produção (Abramides Neto \& Moura, 1943; Bertoni \& Lombardi Neto, 1990; Hudson, 1995).

Embora existam vários tipos de terraços, sua função sempre é parcelar o comprimento de rampa, disciplinando o escoamento superficial de maneira a evitar o aumento do seu volume e velocidade. A escolha do tipo de terraço a ser construído quanto à sua função está intimamente ligada às propriedades físicas do solo que determinam a sua permeabilidade (Bertoni \& Lombardi Neto, 1990). Quanto à função os terraços podem se distinguir dois tipos básicos: os terraços em desnível ou de drenagem e os terraços em nível ou de infiltração. Os terraços de drenagem apresentam gradiente de nível e têm a função de interceptar e escoar a enxurrada, sendo indicados para solos com permeabilidade moderada a lenta, que impossibilitem a infiltração da água proveniente de chuvas de intensidades consideráveis. Estes terraços devem ser associados a canais escoadouros para conduzir a água excedente da capacidade de infiltração do solo. Os terraços em nível ou de infiltração, com a função de reter o escoamento para posterior infiltração, são recomendados para solos que possuam uma boa permeabilidade, possibilitando uma rápida infiltração 
(Abramides Neto, 1956; Correa, 1958; EMBRAPA, 1980; Bertolini et al., 1989; Martins \& Bahia, 1998; Silva, 1998). Em terrenos ou glebas com declive uniforme é possível, ainda, construir terraços paralelos. Esta técnica, apesar de pouco utilizada, visa eliminar a presença de linhas muito curvas e ruas mortas, facilitando o manejo, no entanto, não dispensa a presença de canais escoadouros (Bertoni, 1960; Martins \& Bahia, 1998).

A movimentação do solo para a construção de terraços pode ser feita de duas maneiras básicas: construindo o terraço através de cortes do terreno sempre de cima para baixo, retirando a terra que forma o camalhão da faixa imediatamente superior (terraço tipo Nichols) ou movimentando a terra em uma faixa mais larga de cima para baixo e de baixo para cima, ora em um sentido, ora em outro, visando a construção de canais mais largos (terraço tipo Mangum). Os terraços tipo Nichols podem ser utilizados para terrenos de declive mais acentuado devido à conformação triangular do canal. Por outro lado, o tipo Mangum, com canal mais largo e raso e secção de forma trapezoidal, deve ser utilizado em terrenos de declividade mais suave (Correa, 1958; Bertoni \& Lombardi Neto, 1990; Lombardi Neto et al., 1994a, b; Martins \& Bahia, 1998).

Quanto à dimensão, largura da faixa de movimentação de terra, os terraços podem ser de base estreita, média ou larga, de acordo com a declividade do terreno. Os terraços de base estreita, construídos em uma faixa de movimentação de terra de até $3 \mathrm{~m}$ de largura, são recomendados para as condições em que a construção de terraços de base média e larga não é possível e sua utilização se restringe às pequenas lavouras, terrenos inclinados e propriedades de baixo índice de mecanização agrícola. Os terraços de base média são construídos com a largura de 3 a $6 \mathrm{~m}$, permitindo o cultivo ao longo da maior parte de sua extensão, sendo indicados para terrenos de declividade máxima entre 0,10 a $0,12 \mathrm{~m} \mathrm{~m}^{-1}$ e para lavouras de pequeno a médio porte que possuam disponibilidade de equipamentos de pequeno a médio porte. Os terraços de base larga, mais freqüentemente utilizados, são construídos em uma faixa de movimentação de terra de largura entre 6 a $12 \mathrm{~m}$, por qualquer tipo de implemento. Este é recomendado para grandes lavouras e terrenos com declividade entre 0,06 a 0,08 $\mathrm{m} \mathrm{m}^{-1}$. Apesar de apresentar um elevado custo inicial, esse é compensado logo nos primeiros anos tendo em vista que permite ser cultivado ao longo de praticamente toda sua extensão, não necessitando de capinas, 
manuais além de sua manutenção ser permitida através de preparos normais de solo (EMBRAPA, 1980; Bertoni \& Lombardi Neto, 1990; Lombardi Neto et al., 1994a, b).

Outra classificação dos terraços é quanto à forma de seu perfil: terraço comum e terraço tipo patamar. O terraço comum, mais utilizado, é construído tanto em nível quanto em desnível, em declives inferiores a $0,18 \mathrm{~m} \mathrm{~m}^{-1}$, em condições normais de agricultura, podendo sofrer variações quanto à sua forma. O terraço embutido (canal de forma triangular e talude, que separa o canal do camalhão, praticamente na vertical) é uma das variações do terraço comum, tendo boa aceitação por parte dos agricultores. Outra variação é o murundum ou leirão (canal de forma triangular e camalhão com mais de $2 \mathrm{~m}$ de altura), não muito comum devido ao elevado custo de implantação e manutenção, causa grande alteração na paisagem e a presença de encharcamentos ocasionais, tendo uma baixa aceitação pelos agricultores. Os patamares praticamente originaram os demais terraços e, apesar do tempo, continuam sendo utilizados para a maioria dos solos com declives superiores a 0,18 $\mathrm{m} \mathrm{m}^{-1}$. Neste caso, o terraço não apenas auxilia no controle da erosão mas também facilita as operações de preparo do solo devido à sistematização do terreno (Bertolini et al. 1989; Lombardi Neto et al., 1994a, b). O alto custo de implantação dos patamares é recompensado quando na implantação de culturas de elevado rendimento em áreas valorizadas para este fim (Lombardi Neto et al., 1994a, b; Martins \& Bahia, 1998). Este tipo de terraço também pode apresentar variações conforme o uso e as condições do terreno: terraços de irrigação, para culturas como a do arroz irrigado no Sudeste Asiático e banquetas individuais, para implantação de culturas permanentes, construídas manualmente em terrenos que apresentem obstáculos, como pedras ou afloramentos rochosos, caso do cafeeiro em terrenos de encosta no Estado de São Paulo (Assis, 1954).

Os processos tradicionais de construção de terraços no Estado de São Paulo variaram ao longo dos anos. No entanto, a escolha do tipo de terraço, de infiltração ou de drenagem, de base estreita, média ou larga, freqüentemente empregados, ocorre devido ao comportamento da infiltração de água da chuva (Canettieri, 1989). Os terraços em nível ou de infiltração poderão ser adotados sempre que o volume de água excedente for retido e infiltrado pelo canal. No caso de o volume escoado exceder a 
capacidade de infiltração de água do terraço, recorre-se à construção de terraços em desnível (Bertolini et al., 1989; Lombardi Neto, et al., 1994a, b).

Dentre os terraços de infiltração, o de base larga tem se destacado como a prática de suporte no auxílio de controle da erosão devido a algumas vantagens sobre os demais tipos. Dentre essas vantagens destaca-se o plantio com maior aproveitamento da área, a maior facilidade nos tratos culturais devido a estes serem feitos em contorno, paralelamente as linhas do terraço e o melhor aproveitamento de adubos e corretivos por estes permanecerem na área, sem serem arrastados pelo livre escoamento da água (Zenker, 1978). Abramides Neto (1949 e 1956), Correa (1958) e Bertoni \& Lombardi Neto (1990) também mencionam a importância do maior aproveitamento da água pelas culturas devido a maior captação da água da chuva pelo canal do terraço, principalmente em períodos de maior estiagem.

\subsubsection{Espaçamento entre terraços}

O espaçamento entre terraços se expressa em termos de diferenças de nível, em metros, entre dois terraços sucessivos, ou pela distância horizontal entre os mesmos. A distância entre dois terraços é determinada de maneira que a enxurrada, que escoa por entre eles, não atinja velocidade erosiva; dependente, portanto, da declividade e das condições de solo (Bertoni \& Lombardi Neto, 1990). Esta distância está intimamente ligada à eficiência prática pois quanto maior a distância entre terraços, maiores as facilidades de manejo e menores os custos de implantação e produção agrícola (Griebeler et al., 2000).

Os primeiros estudos sobre espaçamentos que se tem registro foram efetuados por $\operatorname{Ramser}^{1}$ (1917), citado por Bertoni (1959) e Bertoni \& Lombardi Neto (1990), com base em relações empíricas obtidas de dados de várias Estações Experimentais Americanas e que serviu de base para outros estudos sobre o assunto. A partir de então, inúmeros trabalhos vêm sendo desenvolvidos nesta linha. No Brasil, até há pouco tempo, utilizavam-se fórmulas de determinação do espaçamento entre terraços desenvolvidos para as condições de solo e clima dos Estados Unidos, como é o caso da Fórmula de Bentley citado no artigo Terraceamento planejado garante

\footnotetext{
${ }^{1}$ RAMSER, C.E. Prevention of erosion of farm lands by terracing. Washington: D.C., USDA, 1917. 23p. (Bulletin, 512)
} 
controle da erosão (1968) e também pela EMBRAPA (1980), devido à falta de estudos locais. Estas fórmulas levavam à adoção de uma grande quantidade linear de terraços, superestimando a sua capacidade (Griebeler et al., 2000). Em uma tentativa de resolver o problema, Abramides Neto \& Borgonovi (1941), Abramides Neto \& Moura (1943) e Marques ${ }^{2}$ (1950) citado por Bertoni (1959) apresentaram as primeiras tabelas de dimensionamento de terraços com base nas perdas por erosão para diferentes tipos de solo do Estado de São Paulo, reduzindo os espaçamentos adotados anteriormente. Estudos mais aprofundados para as condições de solo e clima de São Paulo foram desenvolvidos por Bertoni (1957 e 1959), o qual resultou em uma equação empírica denominada de "índice de erosão":

$$
E=1,03 \cdot D^{0,65} \cdot C^{0,87}
$$

em que $E$ é o índice de erosão, $D(\%)$ é a declividade do terreno e $C(\mathrm{~m})$ é o comprimento do declive. Este índice foi obtido baseando-se na equação proposta por Zingg (1940) que combina o efeito do comprimento e grau de declive sobre as perdas por erosão. Este índice, apesar de ser baseado em um reduzido número de dados locais de perda anual de solo, permitiu que o autor inferisse que o espaçamento vertical entre dois terraços consecutivos poderia ser estimado por:

$$
E V=0,4518 \cdot K \cdot D^{0,58}
$$

em que $E V(m)$ é o espaçamento vertical entre terraços, $K$ é uma constante empírica dependente do tipo de solo (arenosos=0,835; argilosos $=0,954$ e terras roxas $=1,212)$ e $D(\%)$ é a declividade do terreno. Posteriormente, Bertoni ${ }^{3}(1978)$ citado por Lombardi Neto (1989) ampliou os valores de K para todas as unidades de solo do Estado de São Paulo com base em dados de tolerância de perda de solo, obtidos por Lombardi Neto \& Bertoni (1975). Na falta de detalhamento sobre a influência do manejo do solo e da cultura sobre o espaçamento entre terraços, Lombardi Neto et al. (1989) adequaram a equação desenvolvida por Bertoni em 1957 (eq. 2), portanto,

2 MARQUES, J.Q.A. Conservação de solo em cafezal. Separata do Boletim da Superintendência do Serviço do Café, 235p. 1950.

${ }^{3}$ BERTONI, J. Espaçamento de terraços para os solos do Estado. Campinas: Instituto Agronômico, 1978. 4p. 


$$
E V=0,4518 \cdot K \cdot D^{0,58} \cdot \frac{(u+m)}{2}
$$

em que $u$ é o fator uso da terra e $m$ o manejo do solo (preparo do solo e manejo dos restos culturais). Esta modificação permitiu uma adaptação do espaçamento entre terraços conforme o uso e preparo do solo e o manejo dos restos culturais, no entanto, ainda é uma equação de restrita utilização por ser empiricamente desenvolvida para as condições da região de São Paulo. Uma breve revisão sobre o assunto também pode ser encontrada em Oliveira et al. (1992). Para sistemas de preparo conservacionista de solo, o comprimento crítico de declive, ponto onde ocorre a falha de resíduos culturais na superfície do solo pela ação da enxurrada, descrito por Bertol \& Cogo (1996) e por Bertol et al. (1997), pode ser um outro critério para auxiliar na definição da distância entre terraços.

\subsubsection{Dimensionamento do canal do terraço}

Para que o sistema de terraceamento funcione com plena eficiência é necessário um correto dimensionamento, tanto no que diz respeito ao espaçamento entre terraços quanto à secção transversal, forma e tamanho da área de captação da água pelo canal do terraço. A secção transversal deve ser dimensionada em função do volume de água escoada pelo dado evento de chuva. O primeiro passo para o dimensionamento é determinar o período de retorno de chuvas máximas (recorrência) desejado para a estimativa de enxurradas máximas (Pruski et al., 1994; Hudson, 1995). A secção pode ser dimensionada para a chuva de maior intensidade que já ocorreu no local, principalmente quando vidas correm perigo, porém é economicamente preferível dimensionar a secção dos terraços para períodos de retorno menores, em torno de 10 anos, apesar dos riscos, devido à grande redução dos custos, aumento da área produtiva e a facilidade de manejo (Lombardi Neto, 1989). Quando os terraços são locados com gradiente, a enxurrada deve ser imediatamente conduzida para canais escoadouros para evitar-se os riscos de rompimento do camalhão por transbordamento devido à deposição e permanência da água escoada sobre o canal.

A secção transversal de terraços em nível tem sido normalmente dimensionada para que suporte todo o volume de enxurrada esperado por uma chuva 
máxima de um determinado período de retorno, desprezando-se a evaporação (Bertoni \& Lombardi Neto, 1990). O volume esperado, por metro linear de canal, tem sido dado pela relação entre a área de captação e a lâmina máxima diária precipitada para um dado período de retorno:

$$
V_{e}=A \cdot p \cdot c
$$

em que $V_{e}$ é o volume de água escoada, $A$ é a área da bacia de captação, $p$ é a lâmina precipitada máxima num período de 24 horas e $c$ é o coeficiente de enxurrada. $O$ coeficiente de enxurrada, relação entre a quantidade de enxurrada e a quantidade de chuva, depende da taxa de infiltração e, dessa forma, do solo e da vegetação. A área da bacia de captação é relacionada ao espaçamento horizontal entre os terraços conforme:

$$
A=\text { EH.L.c }
$$

em que $E H$ é o espaçamento horizontal entre terraços e $L$ o comprimento do terraço. Após o conhecimento do volume e área de captação pelo canal, por metro linear, determina-se a capacidade da secção transversal para o armazenamento de todo o volume de água escoada. Como se deseja que o volume de captação $V_{c}$ seja, no mínimo, igual a $V_{e}$, então a secção pode ser expressa por:

$$
S=E H \cdot p \cdot c
$$

em que $S$ é a secção transversal do canal ou área de captação. As dimensões dos taludes somente poderão ser determinadas de acordo com a escolha do formato (Lombardi Neto, 1989; Silva, 1998). Normalmente, a escolha do formato ocorre devido à disponibilidade de equipamentos para a sua construção, não levando em consideração as condições de solo.

Mais recentemente outras formas de se dimensionar os terraços foram relatadas. Pruski et al. (1994) estimaram o escoamento superficial máximo de água a ser acumulado no canal do terraço através do conhecimento da relação intensidadeduração-frequência da chuva e a velocidade de infiltração básica do solo. Pruski et al. (1997), em uma nova tentativa para estimar o escoamento superficial máximo, utilizou-se do conhecimento da chuva total, das abstrações iniciais de água determinadas pelo método da curva-número (descrita em Schwab et al., 1993), da 
infiltração acumulada e da evaporação. Neste estudo, o autor conclui que a utilização de métodos adequados para a determinação de infiltração de água no solo é fundamental para a determinação da seção transversal do terraço. Assim, os métodos tradicionais de dimensionamento de terraço, consagrados pela experiência prática, podem ser aperfeiçoados por uma abordagem física permitindo o dimensionamento mais preciso da área e formato do canal do terraço. Chaves (1996) propôs a substituição dos critérios tradicionais de determinação da seção do terraço pelo critério da probabilidade de falha. O método proposto avalia as incertezas da variabilidade espacial da área da seção causadas por erros de locação e de construção dos terraços e a variabilidade temporal dos dados hidrológicos. É importante salientar que todos os estudos de espaçamento e dimensionamento de terraços em nível visam a segurança quanto à redução das perdas de solo e água aliada a praticidade e economicidade da implantação e manutenção do sistema. Quando o sistema é superdimensionado, aumentam-se os custos de produção e a dificuldade nas operações de implantação e manutenção, ao contrário, poderá acarretar em rompimentos. O rompimento de um dos terraços dentro de uma gleba geralmente acarreta no rompimento dos demais situados abaixo, aumentando ainda mais as perdas por erosão. Rodrigues (1963) aborda esse assunto com maior detalhe.

\subsection{Infiltração sob condições de selamento superficial}

A diferença entre a quantidade de água precipitada e infiltrada no solo durante uma chuva determina o coeficiente e volume da enxurrada e, assim, o poder erosivo da chuva. Além disso, é importante para o dimensionamento da seção transversal do canal do terraço, bem como o espaçamento entre os terraços. A infiltração é um processo dinâmico que não depende apenas das condições iniciais do solo como a porosidade, grau de cobertura, umidade antecedente e umidade dos horizontes. Depende também de processos dinâmicos que ocorrem durante a chuva como a formação ou reformação de selamento superficial pelo impacto direto das gotas da chuva na superfície do solo (Baumhardt et. al., 1990; Levien et al., 2000), o aparecimento de rachaduras na superfície do solo devido à baixa resistência do solo à ação da chuva (Topp \& Davis, 1981) e a redução do gradiente de potencial da água no perfil do solo causado pelo avanço da frente de molhamento (Chow, 1988). 
O selo superficial é caracterizado por uma fina camada de solo, localizada na superfície do terreno, de elevada densidade, baixa porosidade e baixa condutividade hidráulica (Heil et al., 1997). Esta, por sua vez, é resultante de um severo distúrbio estrutural da superfície devido à ação direta das gotas da chuva sobre o solo e da reacomodação de finas partículas transportadas pela enxurrada (Daker, 1953/1954). O selamento superficial, sob condições de chuva ou irrigação pressurizada, é causado pela redução da estabilidade dos agregados, da rugosidade superficial do solo e pela alteração na porosidade superficial, devido principalmente à ação da energia cinética do impacto das gotas da chuva sobre os macroagregados (Duley, 1939; Castro, 1998; Singer \& Bissonnais, 1998). Em regiões áridas ou semi-áridas, a presença de água de baixa salinidade em contato com o solo também pode causar o selamento superficial por induzir a dispersão de argilas (Eltz, 1993).

Devido à alta variabilidade espacial e temporal das características do selo, os modelos que avaliam o movimento da água no solo, como os de infiltração e de condutividade hidráulica, não levam em consideração o selamento superficial, embora comumente ocorra quando na presença de chuvas ou irrigações pressurizadas (Fox et al., 1998). Levien et al. (2000) salientam a importância da determinação da taxa de infiltração de água no solo sob condições de selamento superficial, necessária para o estudo de conservação do solo e da água, pois se sabe que esta condição existe e é variável conforme o manejo dado ao solo. Esta limitação, ou seja, a não consideração da presença de selamento superficial, aliada a suposição de estacionariedade da intensidade de precipitação do evento de chuva, reduz a exatidão dos modelos (Chu, 1978). No intuito de aumentar a confiabilidade dos modelos existentes, dada a importância do fenômeno, alguns trabalhos de modelagem do movimento de água no solo foram desenvolvidos incorporando a presença do selo superficial. Visando a previsão da infiltração de água sob condição de selamento, Chu et al. (1986) adaptaram o modelo de Green-Ampt enquanto Chaves et al. (1993), o modelo de Horton. Topp \& Davis (1981) conduziram seus estudos para condições ainda mais complexas, aplicando técnicas avançadas para o monitoramento da umidade em rachaduras formadas por entre o selo na tentativa de detectar a infiltração. $\mathrm{Na}$ avaliação da condutividade hidráulica sob condições semelhantes, Baumhardt et al. (1990) adaptaram a equação de Richards. Entretanto, o selo é formado em 
situações dinâmicas em que mesmo os modelos baseados na sua existência são incapazes de prever a variabilidade de suas características físicas no tempo e no espaço para os diferentes solos. Alguns trabalhos estão sendo desenvolvidos no sentido de incorporar a dinâmica do selamento superficial mas nem sempre são bem sucedidos devido à dificuldade encontradas na validação para os diferentes solos. Chaves et al. (1993), estudando a infiltração sob condições de selamento, observaram que o comportamento da infiltração apresentava-se de forma sinuosa ao longo do tempo e passaram a atribuir o fenômeno à alternância de formação do selo e sua destruição ao longo de um dado evento erosivo, então, desenvolveram um modelo dinâmico que pode ser facilmente validado para outras condições devido a sua simplicidade, facilidade de calibração e utilização e, ainda tendo a vantagem de pode ser utilizado em previsões da infiltração sob intensidade variável de chuva.

\subsection{Condutividade hidráulica}

Entre as propriedades físicas do solo, a condutividade hidráulica é uma das mais importantes quando se estudam fenômenos que estão ligados ao movimento de água entre estes a infiltração e a redistribuição de água no solo. A condutividade hidráulica do solo pode ser medida por métodos de laboratório ou de campo e em solos saturados como em não-saturados. Dentre os métodos para solos nãosaturados, a técnica do perfil instantâneo, aplicada a campo, baseia-se na equação de Richards, e tem permitido a medição da condutividade hidráulica não-saturada do solo em diversas situações (Freire, 1979; Libardi et al., 1980; Prevedello et al., 1981; Prevedello et al., 1994; Reichardt et al., 1998; Jong van Lier \& Libardi, 1999). A técnica do perfil instantâneo tem a vantagem de poder ser realizada no campo em solo sob condições naturais, mas exige tempo e mão-de-obra. Para solos que apresentam camadas de impedimento hídrico como, por exemplo, compactação em alguma de suas profundidades, o fluxo pode tornar-se um processo tão lento que restringe a utilização do método. A condutividade hidráulica é uma das propriedades do solo que apresenta maior variabilidade espacial (Warrick \& Nielsen, 1980; Webster \& Oliver, 1992) principalmente em faixas de umidade inferior a saturação. Por isso recomenda-se um grande número de observações para uma análise relativamente confiável (Jong van Lier \& Libardi, 1999). 


\subsection{Time Domain Reflectometry (TDR)}

A reflectometria no domínio do tempo (“Time Domain Reflectometry" - TDR), como método de medida da umidade e condutividade elétrica do solo vem se destacando no cenário das técnicas empregadas desde a década de 80 quando Topp e colaboradores a utilizaram para a determinação de uma relação entre constante dielétrica e umidade do solo em diferentes meios porosos (Topp et al., 1980). A técnica utiliza um testador de cabo que mede variações no tempo de propagação de um pulso eletromagnético, provocados por descontinuidades na linha de transmissão. Na prática, o TDR computa o tempo gasto para o pulso eletromagnético ir do começo ao fim da haste do sensor (linha de transmissão) de comprimento conhecido (geralmente de $0,15,0,20$ ou $0,30 \mathrm{~m}$ ), inserida ao solo. Esse tempo está relacionado com a constante dielétrica do solo que, por sua vez, está relacionada à umidade volumétrica do solo (Dirksen, 1999).

Assim como outros métodos de medida direta ou indireta da umidade do solo, a técnica TDR possui vantagens e desvantagens (Schmugge et al., 1980). Entre as vantagens têm-se: a possibilidade de avaliar a umidade do solo in situ, sem maiores perturbações ao solo (método não destrutivo); a obtenção de valores de umidade em regiões muito próximas a superfície (ao contrário do que, por exemplo, a sonda de nêutrons permite); permitir a coleta automática e em tempo real de dados de um ou mais sensores, através de multiplexação; armazenagem dos mesmos, via "datalogger" e; não ser radioativo. Como desvantagens menciona-se o fato de o equipamento possuir um custo relativamente elevado; necessitar da abertura de trincheiras para a instalação das sondas, causando alguns distúrbios ao solo e até mesmo ao sistema radicular. Além disso, a calibração é dependente da estrutura do solo, da presença de metais como ferro, sais e matéria orgânica.

\subsubsection{Calibração do TDR}

A determinação da umidade do solo pelo TDR pode ser feita através da relação empírica entre a umidade volumétrica $(\theta)$ e a constante dielétrica aparente do solo $\left(K_{a}\right)$. Topp et al. (1980), utilizando quatro solos de textura média variando de

franco arenosa à argilosa, demonstraram, em laboratório, que a constante dielétrica aparente é fortemente dependente da umidade volumétrica e, essencialmente, independente do tipo de solo, densidade, conteúdo de sais solúveis e temperatura. 
Topp et al. (1982) ressaltaram que a curva de calibração desenvolvida por Topp et al. (1980) poderia ser utilizada em campo para avaliação da infiltração de água, em solos homogêneos, onde existe uniformidade na constante dielétrica, considerando o fato de que a impedância na resposta do TDR ocorre, exclusivamente, devido a diferenças de umidade do solo pela frente de molhamento. Por outro lado, em solos heterogêneos, a avaliação de impedância na resposta do TDR pode ser atribuída tanto a variações na umidade do solo como a mudanças físicas entre camadas de solo, gerando incertezas quanto à medida da umidade se utilizar uma única curva de calibração. No entanto, esta equação vem sendo amplamente utilizada e considerada como a equação universal de calibração do TDR para solos. A partir de então, a aplicação da técnica TDR em solos foi discutida em diversos trabalhos como Lideu et al. (1986); Dasberg \& Hopmans (1992); Dirksen \& Dasberg (1993); Jacobsen \& Schjonning (1993); Pepin et al. (1995); Yu et al. (1997); Ponizovsky et al. (1999); Yu et al. (1999) entre outros. Outros atributos do solo estão sendo considerados e incorporados à equação de calibração, no intuito de adaptar a equação de Topp para outras condições de solo. Ao utilizar-se a calibração de Topp et al. (1980) para solos tropicais, com grande quantidade de óxidos, principalmente os óxidos de ferro, superestima-se a umidade devido ao aumento da constante dielétrica dos metais em relação aos minerais presentes no solo (Tomaselli, 1997). No caso de solos orgânicos, a presença de matéria orgânica também pode levar a uma superestimativa da umidade devido à maior quantidade de água agregada em sua estrutura em relação à água presente na estrutura mineral, porém, de forma indireta. Nestes casos, necessita-se de calibrações específicas para as condições de solo em estudo. 


\section{MATERIAL E MÉTODOS}

\subsection{Caracterização da área}

A parte experimental dessa pesquisa foi realizada no período de fevereiro de 2000 a janeiro de 2001 na Fazenda Experimental "Areão" da Escola Superior de Agricultura "Luiz de Queiroz" (ESALQ) da Universidade de São Paulo (USP), no município de Piracicaba, Estado de São Paulo, a uma altitude de $576 \mathrm{~m}$ acima do nível do mar, com as coordenadas geográficas de $22^{\circ} 42^{\prime}$ de latitude Sul e $47^{\circ} 30^{\prime}$ de longitude Oeste.

O clima, segundo a classificação de Köppen, é do tipo Cwa, isto é, clima tropical úmido, com verão chuvoso, inverno seco e temperatura do mês mais frio inferior a $18^{\circ} \mathrm{C}$. Dados climáticos do posto meteorológico da ESALQ/USP (média de 30 anos), a $2 \mathrm{~km}$ da área experimental, mostram uma temperatura média do ar de $21,7^{\circ} \mathrm{C}$, temperatura máxima de $40,2^{\circ} \mathrm{C}$ e temperatura mínima de $-1,8^{\circ} \mathrm{C}$, umidade relativa do ar de $0,75 \mathrm{~Pa} \mathrm{~Pa}^{-1}$, velocidade média do vento de $8,6 \mathrm{~km} \mathrm{~h}^{-1}$ e precipitação total anual média de $1394 \mathrm{~mm}$.

O solo do local classifica-se como Latossolo vermelho (Anexo 1 e Anexo 2), representativo na região. Sua declividade média é de $0,08 \mathrm{~m} \mathrm{~m}^{-1}$ ao longo da área experimental.

\subsection{Delineamento experimental}

\subsubsection{Unidades experimentais}

As unidades experimentais foram constituídas por quatro parcelas de $16 \mathrm{~m}$ de largura e $50 \mathrm{~m}$ de comprimento (compreendendo uma área útil de $800 \mathrm{~m}^{2}$ ), todas instaladas na mesma cota conforme está representado na Figura 1. Com o intuito de separar as enxurradas provenientes de cada tratamento, as parcelas foram delimitadas 
nas laterais e parte superior por chapas galvanizadas (com 0,20 m de altura, enterradas no solo cerca de $0,05 \mathrm{~m}$ ). A cota inferior da área das parcelas foi delimitada por um único terraço de infiltração (em nível) o qual foi construído em condições normais de operação através de um terraceador de base larga. Este terraço foi segmentado a cada $16 \mathrm{~m}$ por chapas galvanizadas (de 6,0 m de comprimento e 1,2 m de largura de dimensão, enterradas no solo na profundidade de 1,0 m) visando separar a água acumulada no canal e limitar o fluxo de água no solo entre tratamentos. No canal do terraço foram retiradas amostras para determinação da densidade do solo, curva de retenção e granulometria conforme os itens 3.3.2 a 3.3.4, em três posições e seis profundidades por tratamento. Nas mesmas posições e profundidades foram feitas, posteriormente, determinações de condutividade hidráulica não-saturada (item 3.3.6) e o monitoramento da umidade ao longo do tempo (item 3.3.5)

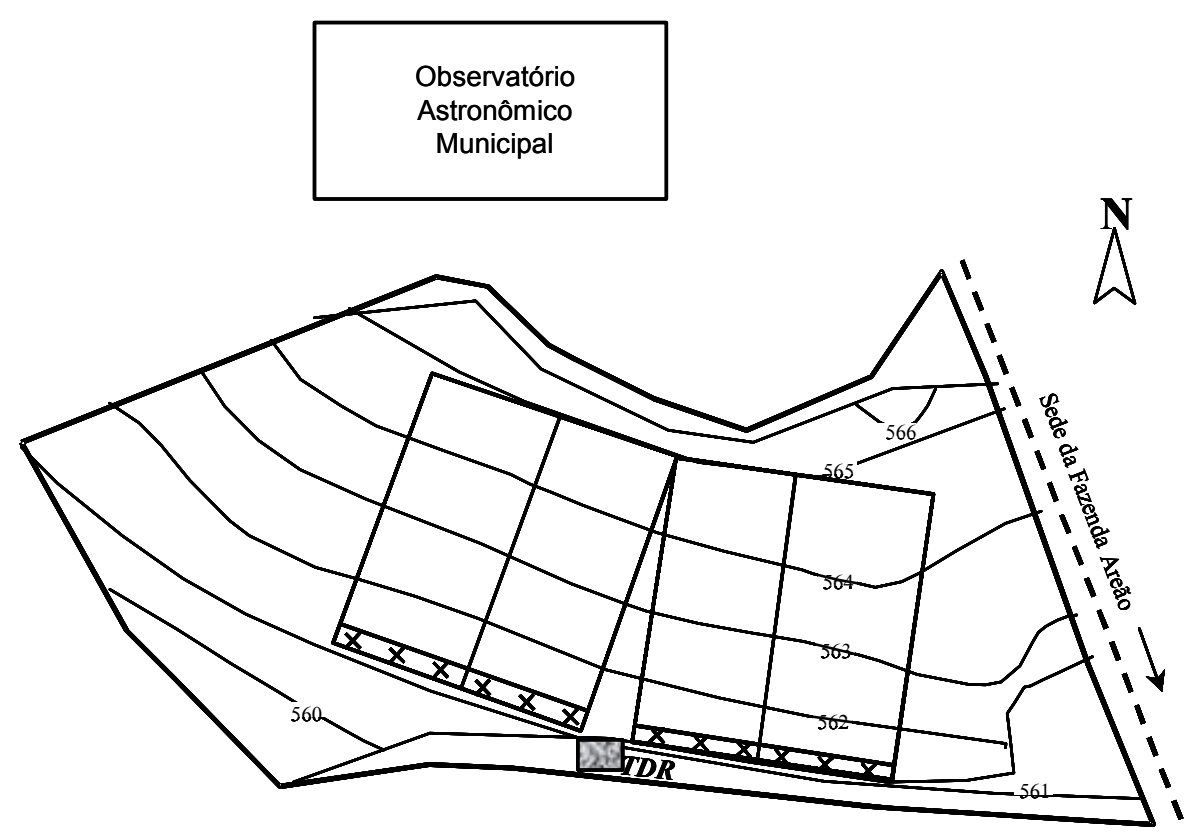

$\times$ Local de amostragem e observação

Figura 1 - Mapa da área experimental mostrando as isolinhas das cotas do terreno, as quatro parcelas, os 12 locais de amostragem e observação no canal do terraço (três por parcela) e a localização do equipamento TDR. 


\subsubsection{Tratamentos}

Os tratamentos foram compostos por diferentes condições de manejo agrícola, de maneira a resultar em diferentes coberturas vegetais e, conseqüentemente, diferentes taxas de infiltração, intensidades de enxurrada e deposição de material erodido no canal do terraço. Nesse tipo de experimento, com parcelas grandes, a realização de repetições de tratamentos torna-se difícil. Devido a esse motivo, cada tratamento foi implantado em apenas uma parcela. Dentre os tratamentos de solo, o de menor cobertura foi o solo mantido permanentemente descoberto e o de maior cobertura foi o cobertura vegetal permanente (grama batatais) na área a montante do canal. A grama foi transplantada na forma de placas no mês de janeiro de 2000. Como tratamentos de coberturas vegetais intermediárias foram escolhidos o preparo convencional do solo seguido de semeadura de milho e a semeadura direta de milho sobre o solo sem preparo, mais comumente conhecida por plantio direto. Devido à compactação do solo pelo uso anterior da área, realizou-se uma escarificação antes da primeira semeadura de milho para a implantação do tratamento plantio direto no mês de dezembro de 1999. Nos demais tratamentos, realizaram-se preparos convencionais "morro-abaixo" que consistiram de uma aração seguida de duas gradagens, no sentido do declive, visando maximizar as perdas de solo em cada tratamento, de acordo com a filosofia de obtenção do fator $C$ da equação universal das perdas de solo (Wischmeier \& Smith, 1978). A semeadura direta do milho ocorreu em dezembro de 1999 no primeiro cultivo e em outubro de 2000 no segundo cultivo, logo após o preparo das parcelas. O terraço (camalhão e canal), foi mantido descoberto para facilitar o manejo e as avaliações na superfície do canal.

\subsection{Amostragens e determinações}

\subsubsection{Pluviometria}

O volume de chuva foi monitorado por um pluviômetro automatizado, modelo CS700-L da Campbell Scientific $(200 \mathrm{~mm}$ de diâmetro de abertura e resolução de $0,254 \mathrm{~mm}$ ), localizado na região central do experimento, próxima ao canal do terraço (Figura 2), durante todo o tempo de avaliação do experimento. Os pulsos do 
pluviômetro foram registrados, de um em um minuto, por um "datalogger" (compilador de dados), modelo CR510.

Os eventos de chuva foram considerados individuais quando separados por um período de no mínimo 6 horas contínuas com menos de 1,27 mm de chuva. Esta quantidade representa $1 / 10$ da quantidade de chuva que é levada em conta no cálculo do índice de erosividade $-\mathrm{El}_{30}$ - de acordo com Wischmeier (1959).
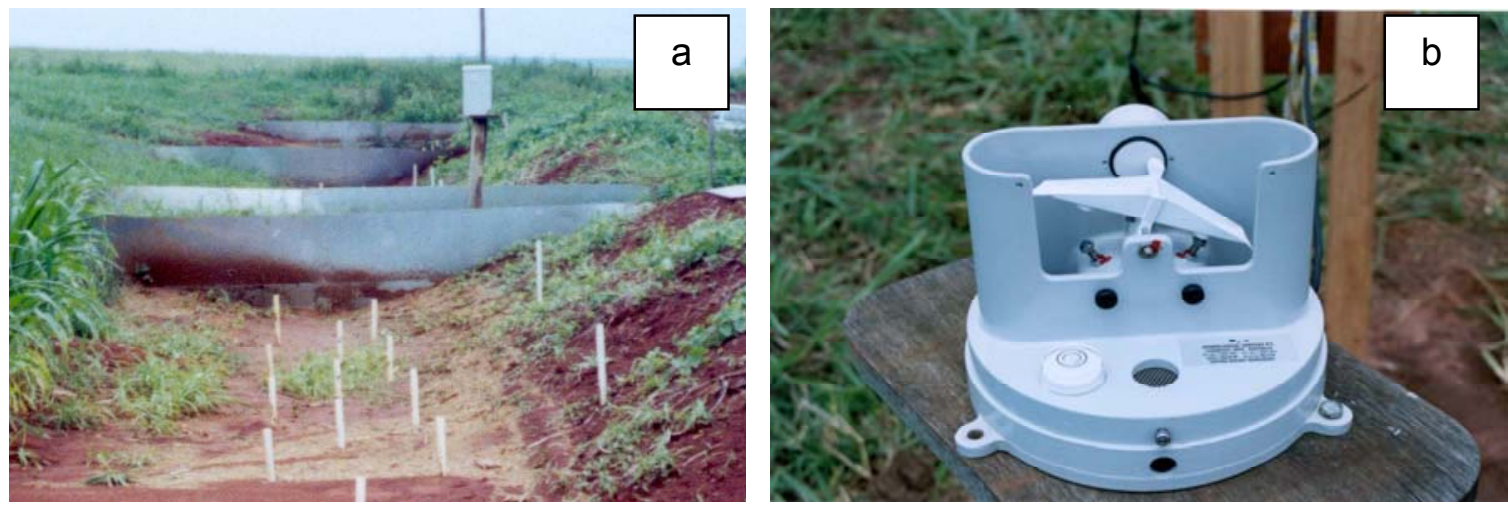

Figura 2 - Localização do pluviômetro na área experimental (a) e detalhe interno do equipamento (b).

\subsubsection{Densidade do solo}

A densidade do solo $\left(\rho, \mathrm{kg} \mathrm{m}^{-3}\right)$ foi determinada em amostras indeformadas de solo coletadas no mês de outubro de 1999, em anéis com dimensões de 0,053 de altura e 0,049 m de diâmetro, em três locais de amostragem por parcela, locados a cada $4 \mathrm{~m}$ distância entre si e das laterais da parcela (Figura 1), e em cada profundidade $(0,05,0,10,0,20,0,40,0,60$ e $0,80 \mathrm{~m})$, totalizando 18 amostras por parcela. Nestes mesmos locais foram coletadas amostras para determinação da curva de retenção e granulometria do solo (itens 3.3.3 e 3.3.4). As amostras de densidade foram secas em estufa a $105^{\circ} \mathrm{C}$ para a determinação de massa dos sólidos e posterior determinação da densidade do solo seguindo a metodologia de Blake \& Hartge (1986). 


\subsubsection{Curva de retenção de água no solo}

A curva de retenção de água no solo foi determinada em amostras indeformadas do solo do canal do terraço, retiradas nos mesmos três locais de amostragem e profundidades $(0,05,0,10,0,20,0,40,0,60$ e $0,80 \mathrm{~m})$, por tratamento, onde foram coletadas as amostras para a determinação da densidade do solo. As amostras também foram coletadas no mês de outubro de 1999, em anéis de amostragem com 0,05 $\mathrm{m}$ de diâmetro interno e 0,03 $\mathrm{m}$ de altura com ajuda de um amostrador do tipo "Uhland". Em cada local de amostragem e profundidade foram retiradas duas amostras, totalizando 36 amostras por tratamento ou 144 amostras no total. As amostras foram utilizadas para determinar a umidade gravimétrica em tensões pré-estabelecidas. As tensões foram aplicadas no laboratório de Física do Solo do Departamento de Ciências Exatas em caixas de areia (Figura 3a) para as tensões até $10 \mathrm{kPa}$ e em câmara de pressão (Figura 3b) para as tensões acima de $10 \mathrm{kPa}$, seguindo metodologia de Klute (1986). Aplicaram-se as tensões de 1, 2, 6, 10, 20, 33, 100 e $300 \mathrm{kPa}$, sucessivamente, em todas as amostras, sendo também aplicada a tensão de $500 \mathrm{kPa}$ nas amostras coletadas a 0,05 e 0,10 m de profundidade. Depois de atingido o equilíbrio em cada tensão, as amostras foram pesadas e a umidade gravimétrica $\left(U, \mathrm{~kg} \mathrm{~kg}^{-1}\right)$, referente a cada sucção, foi calculada pela diferença entre a massa da amostra úmida e a massa da amostra seca. A massa seca foi obtida após secagem das amostras em estufa a $105^{\circ} \mathrm{C}$ por 48 horas. Com base nos valores obtidos e conhecendo-se a densidade do solo e da água, calculou-se a umidade volumétrica $\left(\theta, \mathrm{m}^{3} \mathrm{~m}^{-3}\right)$ e expressou-se a curva de retenção de água no solo referente a cada local e profundidade de amostragem na forma de parâmetros da equação de ajuste proposta por van Genuchten (1980):

$$
\theta=\theta_{r}+\frac{\theta_{s}-\theta_{r}}{\left[1+\left(\alpha\left|\psi_{m}\right|\right)^{n}\right]^{m}}
$$

onde $\psi_{m}(\mathrm{kPa})$ é o potencial matricial, $\theta_{r}\left(\mathrm{~m}^{3} \mathrm{~m}^{-3}\right)$ é a umidade residual, $\theta_{s}\left(\mathrm{~m}^{3} \mathrm{~m}^{-3}\right)$ é a umidade de saturação, e $\alpha\left(\mathrm{kPa}^{-1}\right), m$ e $n$ são os demais parâmetros empíricos da equação. $O$ ajuste foi feito utilizando-se um programa de ajuste de curvas que emprega o método iterativo de Newton-Rapshson, minimizando a soma dos quadrados dos 
desvios em relação à umidade, estimando os cinco parâmetros $\theta_{\mathrm{r}}, \theta_{\mathrm{s}}, \alpha, m$ e $n$ independentemente.
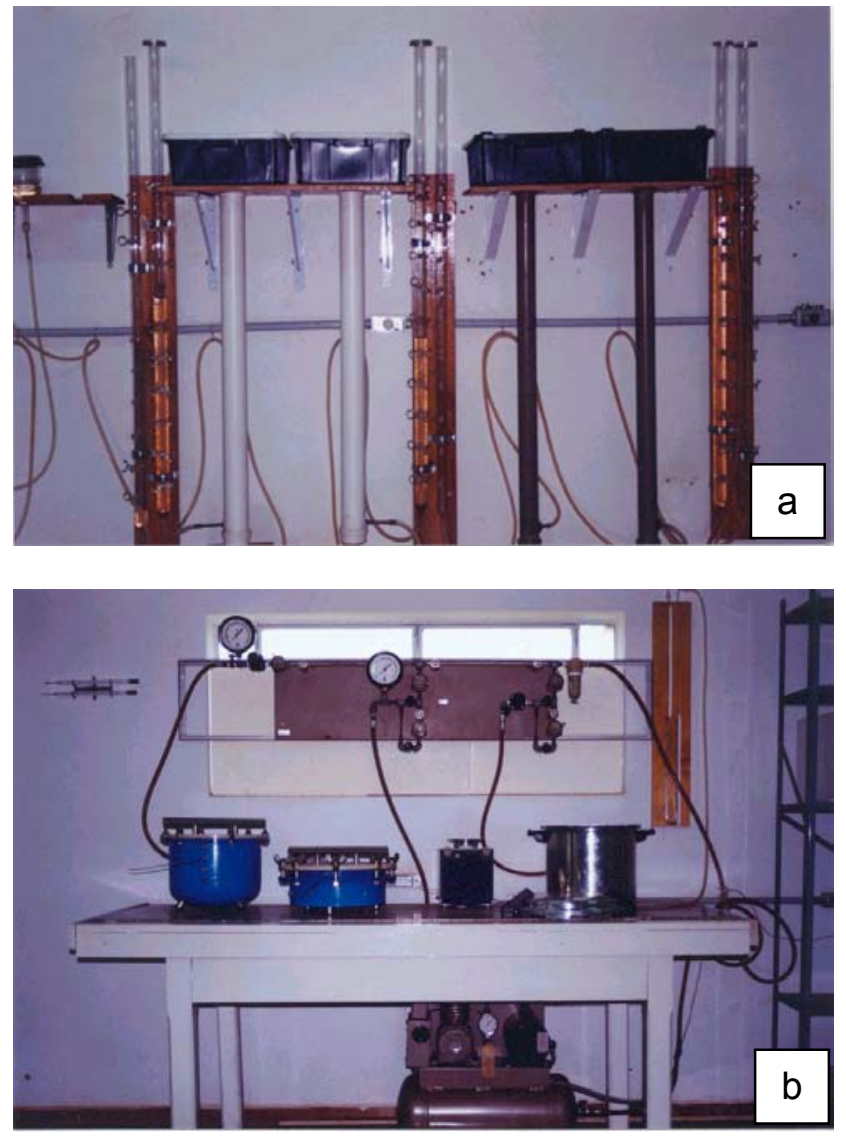

Figura 3 - Caixas de areia (a) e câmaras de pressão (b) para a determinação da curva de retenção de água no solo.

\subsubsection{Granulometria do solo}

Visando a caracterização granulométrica do solo do canal do terraço foram utilizadas amostras compostas dos três locais de amostragem por tratamento, nas mesmas profundidades em que foram coletadas as amostras para a determinação de densidade e da curva de retenção de água no solo $(0,05,0,10,0,20,0,40,0,60$ e $0,80 \mathrm{~m})$.

$\mathrm{Na}$ fase inicial do experimento (janeiro de 2000) foram coletadas amostras compostas por material de três locais de amostragem da superfície do solo a montante do terraço em cada tratamento e ao final de cada período de cultivo (junho de 2000, 
março de 2001) coletaram-se cinco amostras deformadas do material erodido e depositado sobre o canal em cada tratamento, visando a caracterização desse, ao longo das duas safras de cultivo, nos diferentes tratamentos. Para a determinação das frações granulométricas das amostras de solo foram utilizadas $50 \mathrm{~g}$ de terra fina seca ao ar (TFSA), passadas pela peneira de $2 \mathrm{~mm}$ de diâmetro. Estas foram colocadas em frascos com uma solução dispersante composta de hidróxido de sódio e hexametafosfato de sódio. Os frascos foram agitados por 12 horas. Após, seus conteúdos foram transferidos para provetas com capacidade de 1 I e seu volume foi completado para determinação dos teores de silte e argila pelo método do densímetro, conforme apresentado em Gee \& Bauder (1986). A seguir, o conteúdo das provetas foi passado por uma peneira de malha de $0,053 \mathrm{~mm}$ de diâmetro, lavado com jatos finos de água e levado para secar em estufa a $105^{\circ} \mathrm{C}$ por 24 horas para determinação da fração areia. Esta foi fracionada em cinco categorias: areia muito grossa (AMG: fração entre 2,00 e 1,00 mm); areia grossa (AG: fração entre 1,00 e 0,50 mm); areia média (AM: fração entre 0,50 e 0,25 mm); areia fina (AF: fração entre 0,25 e 0,105 mm); e areia muito fina (AMF: fração entre 0,105 e 0,053 mm).

\subsubsection{Umidade do solo}

A umidade do solo foi monitorada, abaixo da superfície do canal do terraço (mantido permanentemente descoberto), nos mesmos três locais de amostragem de cada tratamento em que foram coletadas as amostras de densidade e da curva de retenção (Figura 1). Em cada local de observação, nas profundidades de 0,05, 0,10, $0,20,0,40,0,60$ e $0,80 \mathrm{~m}$, de cada tratamento foi instalado um conjunto de sensores de umidade tipo "guias de onda". Os sensores foram interligados a multiplexadores (16 canais) por meio de extensões coaxiais (comprimentos variando de 10 a $40 \mathrm{~m}$, conforme a distância do sensor ao multiplexador) e, por conseguinte, a um equipamento de "Time domain reflectometry" (TDR), com "datalogger" (compilador de dados), modelo TRASE-BE (Figura 4). O "datalogger" registrou as leituras das constantes dielétricas do solo $\left(\mathrm{K}_{\mathrm{a}}\right)$ medidas pelo TDR, assim como data e horário das leituras, além de informações adicionais referentes a cada sensor como, por exemplo, a presença de erros na leitura. Durante o primeiro ano de implantação do experimento ( $1^{a}$ safra: 1999/2000) as medidas de $K_{a}$ foram efetuadas, automatizadamente, de 30 
em 30 minutos. No segundo ano de cultivo ( $2^{a}$ safra: 2000/2001), devido a um defeito ocorrido nos multiplexadores, não se dispunha mais desse equipamento e as medidas foram tomadas manualmente antes, durante e logo após cada evento de chuva. Nesse $2^{\circ}$ ano, na ausência de chuva as leituras foram efetuadas somente uma vez por dia.

Optou-se pelo TDR como equipamento de medição de umidade por ser um dos poucos instrumentos que apresenta um tempo de resposta muito pequeno a variações de umidade, além de ser automatizável e pode ser instalado no solo sem necessidade de uma perturbação superficial permanente. A umidade do solo função da leitura do TDR foi estimada pela equação de calibração.

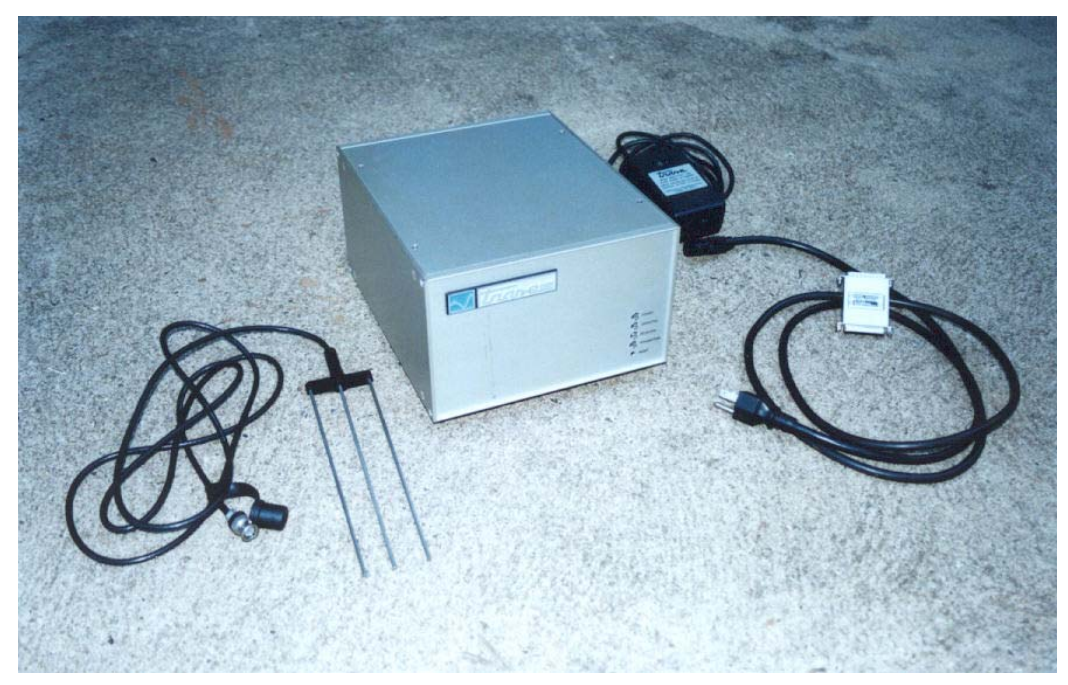

Figura 4 - TDR modelo TRASE-BE e guia de onda para medida de umidade do solo.

\subsubsection{Calibração do TDR}

O equipamento de TDR foi calibrado em amostras de solo, após $01^{\circ}$ ano de cultivo, no Laboratório de Física do Solo do Departamento de Ciências Exatas, ESALQ/USP. As amostras de solo foram coletadas em setembro de 2000, nas profundidades $0,05,0,10,0,20,0,40,0,60$ e 0,80 $\mathrm{m}$, em um único local de amostragem próximo às parcelas, secas ao ar e peneiradas por uma malha de $2 \mathrm{~mm}$. O solo de cada profundidade foi acondicionado em uma coluna de PVC, de 0,25 m de altura e $0,10 \mathrm{~m}$ de diâmetro, após a determinação de sua umidade inicial, estabelecendo a densidade média encontrada no campo, em cada profundidade. 
Nessas colunas, a constante dielétrica do solo úmido $\left(\mathrm{K}_{\mathrm{a}}\right)$ foi medida em dependência da umidade do solo, iniciando-se com o solo seco ao ar. O umedecimento foi conduzido de maneira gradual e homogênea, aplicando-se pequenas quantidades de água através de uma proveta. A leitura de $\mathrm{K}_{\mathrm{a}}$ somente foi realizada alguns dias após a aplicação da água, de maneira a permitir a redistribuição da água no solo. As colunas foram freqüentemente giradas para melhor homogeneizar a distribuição da água no solo. Antes da leitura, a umidade do solo foi calculada por pesagem. Através do conhecimento da umidade gravimétrica $(U)$, da densidade média do solo por profundidade e da densidade da água ( $\rho_{\mathrm{s}}$ e $\rho_{\mathrm{a}}$, respectivamente) para a obtenção da umidade volumétrica $(\theta)$ e do valor da constante dielétrica $\left(K_{a}\right)$ em cada condição de umidade do solo, obtiveram-se 17 valores de $\theta$ versus $K_{a}$ para cada profundidade. Esses pares de dados foram ajustados à equação

$$
\theta=a+\frac{b}{\sqrt{K_{a}}}
$$

em que $a\left(\mathrm{~m}^{3} \mathrm{~m}^{-3}\right)$ e $b\left(\mathrm{~m}^{3} \mathrm{~m}^{-3}\right)$ são constantes empíricas de ajuste.

\subsubsection{Condutividade hidráulica do solo não saturado}

A condutividade hidráulica $(K)$ em função da umidade do solo $(\theta)$ foi determinada através do método do perfil instantâneo (Green et al., 1986; Hillel et al., 1972) nos mesmos três locais de observação e profundidades, por tratamento.

No método do perfil instantâneo, procura-se uma solução para a equação de Richards

$$
\frac{\partial \theta}{\partial t}=\frac{\partial}{\partial z}\left(K(\theta) \frac{\partial \psi_{t}}{\partial z}\right)
$$

em que $\theta\left(\mathrm{m}^{3} \mathrm{~m}^{-3}\right)$ é a umidade volumétrica, $t(\mathrm{~h})$ é o tempo, $K\left(\mathrm{~m}^{2} \mathrm{~h}^{-1} \mathrm{kPa}^{-1}\right)$ é a condutividade hidráulica, $\psi_{t}(\mathrm{kPa})$ é o potencial total da água e $z(\mathrm{~m})$ é a coordenada vertical de posição. Integrando a equação de Richards com relação à profundidade $z$, entre os limites $z=0$ e $z=z$, com as seguintes condições de contorno: 


$$
\begin{aligned}
& z=0 ; t>0 ; q=0 \\
& z=z ; t>0 ; q=q_{z}
\end{aligned}
$$

em que $q\left(\mathrm{~m} \mathrm{~s}^{-1}\right)$ é a densidade de fluxo em uma determinada profundidade, obtém-se:

$$
\int_{0}^{z} \frac{\partial \theta}{\partial t} \partial z=\left.K(\theta) \frac{\partial \psi_{t}}{\partial z}\right|_{z}=q_{z}
$$

ou, rearranjando

$$
\left.K(\theta)\right|_{z}=\frac{\int_{0}^{z} \frac{\partial \theta}{\partial t} \partial z}{\left.\frac{\partial \psi_{t}}{\partial z}\right|_{z}}=\frac{\frac{\partial h_{z}}{\partial t}}{\left.\frac{\partial \psi_{t}}{\partial z}\right|_{z}}
$$

em que $h_{z}\left(\mathrm{~m}^{3} \mathrm{~m}^{-2}\right)$ é a armazenagem de água no solo entre a superfície $(z=0)$ e a profundidade $z$. Por meio de medidas simultâneas de umidade e de potencial total ao longo do perfil de solo durante a redistribuição de água, determinam-se as variações de armazenagem $h_{z}$ com o tempo t e o gradiente de $\psi_{\mathrm{t}}$ ao longo de $\mathrm{z}$ que aparecem na equação (10) e então o valor de $\mathrm{K}(\theta)$. Normalmente os valores de $\mathrm{K}(\theta)$ apresentam uma relação exponencial com a umidade e a função $K(\theta)$ pode ser expressa pela equação

$$
K(\theta)=K_{s} e^{\gamma\left(\theta-\theta_{s}\right)}
$$

em que $\gamma$ é uma constante adimensional e $K_{s}\left(\mathrm{~m}^{2} \mathrm{~h}^{-1} \mathrm{kPa} \mathrm{a}^{-1}\right)$ e $\theta_{s}\left(\mathrm{~m}^{3} \mathrm{~m}^{-3}\right)$ são os valores de $\mathrm{K}$ e $\theta$ para o solo saturado com água. Esta função, equivale a

$$
K(\theta)=K^{*} e^{\gamma(\theta)}
$$

em que $K^{*}\left(\mathrm{~m}^{2} \mathrm{~h}^{-1} \mathrm{kPa}{ }^{-1}\right)$ é o valor de $\mathrm{K}$ para o solo à umidade zero.

Para a obtenção de $\partial \mathrm{h}_{\mathrm{z}} / \partial \mathrm{t}$ e $\partial \psi_{\mathrm{t}} / \partial \mathrm{z}$ da eq. 11, nos meses de julho e agosto de 2000, o canal do terraço foi mantido com uma lâmina de água em sua superfície até a umidade do perfil tornar-se bastante elevada. Atingida a condição quase saturada, a irrigação foi interrompida e a superfície do solo coberta com lona plástica para satisfazer à primeira condição de contorno (Figura 5). A umidade do solo foi, então, 
automaticamente monitorada pelo TDR, em intervalos de 30 em 30 minutos durante 22 dias, nas profundidades de $0,05,0,10,0,20,0,40,0,60$, e $0,80 \mathrm{~m}$, permitindo o cálculo de $\psi_{\mathrm{t}}$ (pelas eq. 10 e 11) e de $\mathrm{h}_{\mathrm{z}}$ para cada profundidade e a cada instante. Esses dados permitiram a estimativa dos valores de $\mathrm{K}^{*}$ e $\gamma$ (eq. 13) utilizando-se uma rotina computacional baseada no método de cálculo de Hillel et al. (1972), descrito em Jong van Lier \& Libardi (1999).

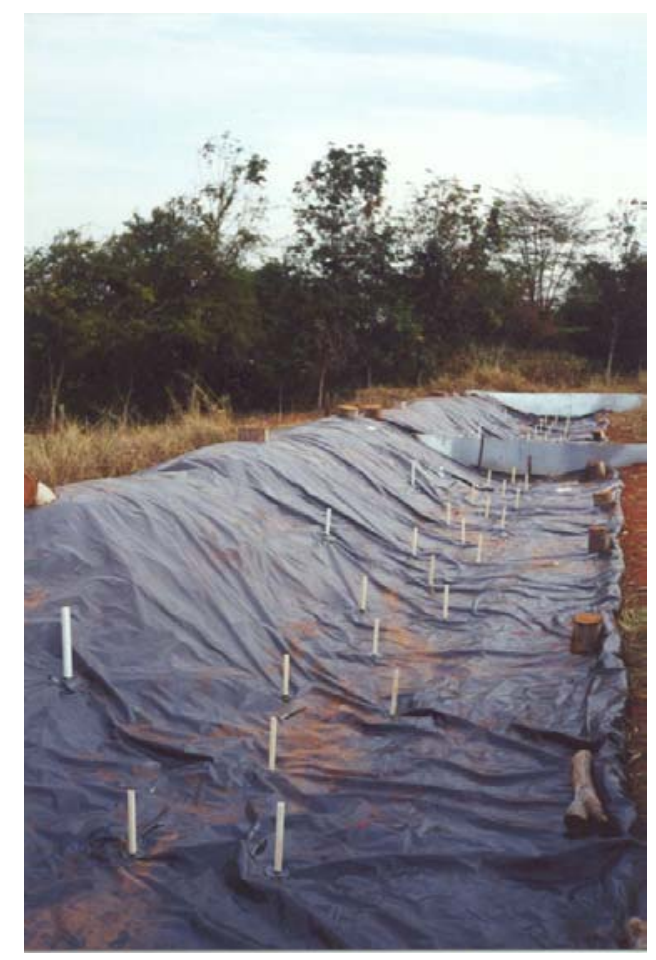

Figura 5 - Terraço coberto por lona plástica para a medição da condutividade hidráulica do solo em função de sua umidade.

\subsubsection{Movimento sub-superficial de água no solo}

Visando a avaliação do movimento sub-superficial de água no solo foram estimadas as densidades de fluxo de água, nas mesmas profundidades do solo $(0,05$, $0,10,0,20,0,40,0,60$ e $0,80 \mathrm{~m}$ ) e locais de observação em que foram determinadas a condutividade hidráulica, a densidade do solo e a curva de retenção, segundo a equação de Darcy-Buckingham 


$$
q_{(z ; z+1)}=\bar{K}_{(z ; z+1)} \frac{d \psi_{t}}{d z}
$$

em que $q_{(z ; z+1)}\left(\mathrm{m} \mathrm{h}^{-1}\right)$ é a densidade de fluxo entre a camada $z$ e a camada $\mathrm{z}+1$, $\bar{K}_{(z ; z+1)}\left(\mathrm{m}^{2} \mathrm{~h}^{-1} \mathrm{kPa}^{-1}\right)$ é a condutividade hidráulica média entre as duas camadas e $d \psi_{t} / d z\left(\mathrm{kPa} \mathrm{m}^{-1}\right)$ é o gradiente de potencial total no sentido vertical entre as duas profundidades, $z$ e $z+1$.

A condutividade hidráulica média entre duas profundidades foi calculada considerando-se que os valores de $\mathrm{K}$ foram distribuídos. Dessa forma,

$$
\bar{K}_{(z ; z+1)}=e^{\frac{\ln K_{z}+\ln K_{z+1}}{2}}=\sqrt{K_{z} \cdot K_{z+1}}
$$

em que $K_{z}$ é a condutividade hidráulica do solo não saturado da camada e $K_{z+1}$ é a condutividade hidráulica do solo não saturado da camada $z+1$, posicionada imediatamente abaixo. $K_{z}$ e $K_{z+1}$ foram calculados pela eq. 13 .

Conhecendo-se os valores de umidade no tempo e as curvas de retenção de água no solo pôde-se estimar os potenciais matriciais através de um rearranjo da equação de van Genuchten (eq. 7)

$$
\left|\psi_{m}\right|=\frac{\left(\left(\frac{\theta_{s}-\theta_{r}}{\theta-\theta_{r}}\right)^{m^{-1}}-1\right)^{n^{-1}}}{\alpha}
$$

Com os valores de $\psi_{m}$ assim obtidos calcularam-se $\psi_{t}$ e $d \psi_{t} / d z$, em cada ponto de observação e profundidade.

Eventuais leituras perdidas foram desconsideradas do cálculo da condutividade hidráulica do solo não saturado. Nesses casos, a condutividade hidráulica média assumiu o valor da condutividade hidráulica de uma das camadas. Nos casos esporádicos em que não houve valor para alguma das camadas, a densidade de fluxo não pôde ser calculada. Nesses casos, a representação da 
densidade de fluxo foi feita através do valor médio entre as demais repetições de cada parcela e camada de solo.

\subsubsection{Estimativa do acúmulo de deposição de solo no canal}

Vinte e uma estacas de $30 \mathrm{~cm}$ de altura foram distribuídas no canal do terraço de cada tratamento, ao longo de três linhas de 7 pontos cada e espaçadas de $1 \mathrm{~m}$ na linha e 0,4 m na entre linha (Figura 6), para a estimativa do acúmulo de deposição de solo no canal e perda de solo da área a montante. A linha mais próxima da cota mais elevada do terraço (camalhão) foi desconsiderada do cálculo das alturas de perdas de solo devido à ocorrência de deposições de solo proveniente do camalhão do terraço e não do tratamento em estudo naquela linha, tendo-se, assim, 14 pontos de observação. Após os eventos de chuva erosiva foram avaliadas as alturas de perdas de solo, em cada ponto de observação, medindo-se a altura das estacas acima da superfície e subtraindo-se da altura inicial $(30 \mathrm{~cm})$. Como estimativa da perda do solo em cada tratamento, utilizou-se a média dos valores das alturas de perdas de solo obtidas nos 14 pontos de observação.

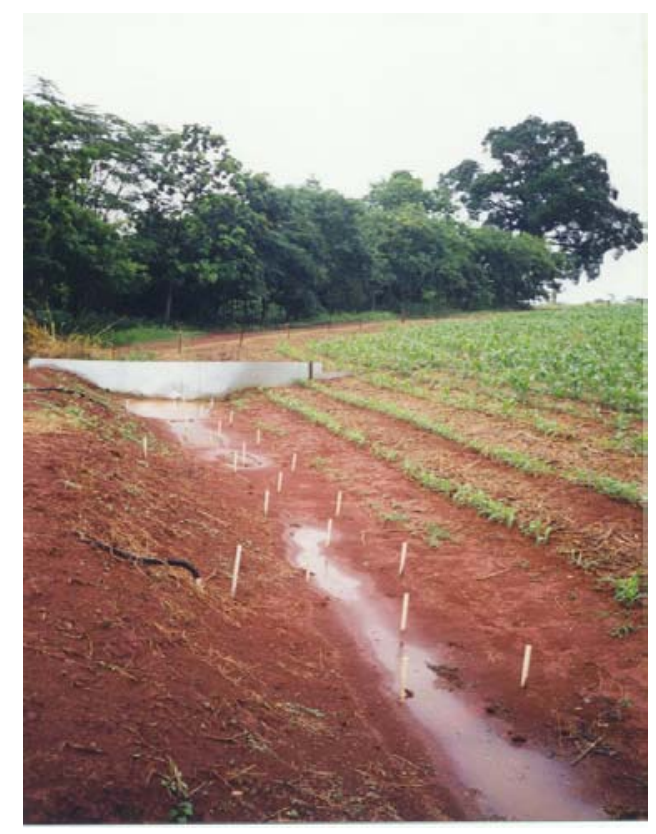

Figura 6 - Pontos de observação (estacas brancas, no centro do canal) para o monitoramento da perda de solo no canal do terraço da parcela plantio direto. 


\subsubsection{Armazenagem de água no solo do canal do terraço}

A armazenagem de água foi calculada para a profundidade de 0 a $0,9 \mathrm{~m}$ ao longo do perfil do canal do terraço de cada tratamento, nas três repetições e para os meses de março e dezembro de 2000, os quais correspondem à primeira e segunda safra de cultivo de milho, respectivamente. Para tanto foram calculadas as armazenagens parciais nas camadas de 0 a $0,075 \mathrm{~m}$, de 0,075 a 0,15 m, de 0,15 a $0,30 \mathrm{~m}$, de 0,30 a $0,50 \mathrm{~m}$, de 0,50 a $0,70 \mathrm{~m}$ e de 0,70 a $0,90 \mathrm{~m}$ referentes às leituras obtidas pelos sensores de TDR instalados nas profundidades de $0,05,0,10$, $0,20,0,40,0,60$ e $0,80 \mathrm{~m}$, respectivamente, em cada ponto de observação, para posterior somatório e obtenção da armazenagem total do perfil em cada uma das repetições por tratamento. Na falta esporádica de leitura de um ou mais sensores devido a alguma falha do equipamento, a armazenagem de água da camada foi calculada através da leitura do sensor imediatamente acima. No caso de falhas do sensor instalado na menor profundidade $(0,05 \mathrm{~m})$, a armazenagem foi calculada pela leitura do sensor imediatamente abaixo.

Como houve, ao longo do período de experimentação, deposição de material erodido na superfície do canal, a armazenagem de água no perfil de solo do canal do terraço foi, também, calculada corrigindo-a para a presença dessa deposição, considerando-se a altura média de solo depositado em cada tratamento ao longo do tempo. Somando-se a altura média de solo depositado sobre o canal à altura da camada mais superficial estimou-se a armazenagem parcial de água corrigida para esta camada, corrigindo-se a armazenagem total em cada perfil. A armazenagem total, corrigida ou não, foi expressa pela média das três repetições por tratamento.

\subsubsection{Taxa de infiltração de água no canal e na área a montante após chuvas}

Pela equação do balanço hídrico, considerando não haver transpiração e fluxo lateral

$$
i_{t}=\frac{d h}{d t}+q
$$


em que $i_{t}\left(\mathrm{~m} \mathrm{~h}^{-1}\right)$ é a taxa de infiltração de água no canal do terraço; $d h / d t\left(\mathrm{~m} \mathrm{~h}^{-1}\right)$ corresponde a variação da armazenagem de água do canal do terraço no tempo, entre a superfície e a profundidade considerada (estimada graficamente); e $q\left(\mathrm{~m} \mathrm{~h}^{-1}\right)$ é a densidade de fluxo na profundidade considerada.

Pela eq. 17, a taxa de infiltração de água no perfil de solo do canal do terraço de cada tratamento foi estimada pela média das três repetições por profundidade para alguns eventos de chuva, considerando-se:

$\left.1^{\circ}\right)$ a taxa de variação da armazenagem de água $(d h / d t)$ entre a superfície e a profundidade máxima de observação $(0,90 \mathrm{~m})$, supondo não haver fluxo de água nessa profundidade $\left(q_{0,90}=0\right)$; e

$2^{\circ}$ ) a taxa de variação da armazenagem de água entre a superfície e a profundidade de 0,30 $\mathrm{m}$ e as densidades de fluxo nessa profundidade.

Conhecendo-se o volume de cada chuva que precipitou na área e considerando-se a área das parcelas $\left(A_{a}=800 \mathrm{~m}^{2}\right.$, item 3.2.1), calculou-se o volume de água infiltrada na área a montante do terraço $\left(V_{a}, \mathrm{~m}^{3}\right)$, conforme:

$$
V_{a}=\left(h_{a} \cdot A_{a}\right)-\left(I_{t} \cdot A_{t}\right)
$$

em que $h_{a}(\mathrm{~m})$ corresponde à lâmina de chuva precipitada sobre a área de cada parcela; $I_{t}(\mathrm{~m})$ é a lâmina de água infiltrada no canal do terraço de cada tratamento (estimada multiplicando-se o valor de $i_{t}$ da eq. 17 pelo tempo de duração do evento); e $A_{t}\left(\mathrm{~m}^{2}\right)$ corresponde à área total do canal do terraço.

Para a estimativa da área do canal do terraço utilizou-se a largura da parcela (16 m) e seu comprimento para a deposição de água. Esse comprimento foi estimado em função de observações de campo, que resultaram no valor de 0,6 m para os tratamentos grama, plantio direto e preparo convencional. Para o tratamento solo nu esse comprimento foi de $1,5 \mathrm{~m}$ no $1^{\circ}$ ano de cultivo e, devido a o volume de deposição de solo sobre o canal desse tratamento, o comprimento aumentou para $1,8 \mathrm{~m}$ no e $2^{\circ}$ ano de cultivo. O volume de água infiltrado em cada terraço foi representado pela média obtida nas três repetições em cada tratamento. 
A taxa de infiltração de água no solo da área total de cada tratamento foi obtida através do volume de água infiltrado (eq.18) na área a montante do terraço, considerando-se o tempo de infiltração de água na área igual ao tempo de duração da chuva, conforme

$$
i_{a}=\frac{V_{a}}{A_{a} \cdot t_{c}}
$$

em que $i_{a}\left(\mathrm{~m} \mathrm{~h}^{-1}\right)$ é a taxa de infiltração na área total de cada tratamento; $t_{c}(\mathrm{~h})$ é o tempo de duração da chuva. 


\section{RESULTADOS E DISCUSSÃO}

\subsection{Caracterização do solo}

\subsubsection{Densidade}

A densidade média do solo entre tratamentos, repetições e profundidades foi de $1049 \mathrm{~kg} \mathrm{~m}^{-3}$. Verifica-se que o solo praticamente não apresentava diferenças quanto à densidade, tanto em profundidade quanto entre os tratamentos (Tabela 1). Diferença significativa ao nível de $5 \%$ de probabilidade ocorreu apenas entre o tratamento plantio direto e o preparo convencional e solo nu na profundidade $0,10 \mathrm{~m}$ e dentro do tratamento solo nu entre as profundidades de 0,05 e 0,40 m.

Tabela 1. Densidade do solo $\left(\mathrm{kg} \mathrm{m}^{-3}\right)$ nos tratamentos e profundidades em estudo (média de três repetições).

\begin{tabular}{lrrrrrr}
\hline \multirow{2}{*}{ Tratamento } & \multicolumn{7}{c}{ Profundidade $(\mathrm{m})$} \\
\cline { 2 - 7 } & 0,05 & 0,10 & 0,20 & 0,40 & 0,60 & 0,80 \\
\hline Grama & $1095 \mathrm{Aa}^{1}$ & $1041 \mathrm{ABa}$ & $1006 \mathrm{Aa}$ & $1031 \mathrm{Aa}$ & $1023 \mathrm{Aa}$ & $1026 \mathrm{Aa}$ \\
Plantio Direto & $1044 \mathrm{Aa}$ & $983 \mathrm{Aa}$ & $1039 \mathrm{Aa}$ & $985 \mathrm{Aa}$ & $980 \mathrm{Aa}$ & $1018 \mathrm{Aa}$ \\
Preparo Convencional & $1109 \mathrm{Aa}$ & $1102 \mathrm{Ba}$ & $1075 \mathrm{Aa}$ & $1046 \mathrm{Aa}$ & $1039 \mathrm{Aa}$ & $1050 \mathrm{Aa}$ \\
Solo Nu & $1154 \mathrm{Ab}$ & $1082 \mathrm{Bab}$ & $1077 \mathrm{Aab}$ & $1023 \mathrm{Aa}$ & $1071 \mathrm{Aab}$ & $1081 \mathrm{Aab}$ \\
\hline
\end{tabular}

${ }^{1}$ Médias seguidas por letras maiúsculas iguais, na mesma coluna, não diferem estatisticamente pelo Teste Tukey ao nível de $5 \%$ de probabilidade; Médias seguidas por letras minúsculas iguais, na mesma linha, não diferem estatisticamente pelo Teste Tukey ao nível de $5 \%$ de probabilidade.

\subsubsection{Granulometria}

Em semelhança à densidade (item 4.1.1), a distribuição granulométrica do solo foi bastante parecida entre os tratamentos e ao longo dos seus perfis (Tabela 2), embora não estatisticamente comprovado pela ausência de repetições. De acordo com 
o triângulo textural (Lemos \& Santos, 1996), classifica-se o solo na classe muito argilosa, em todos os tratamentos e profundidades.

Tabela 2. Granulometria do solo no canal do terraço nos tratamentos grama $(\mathrm{Gr})$, plantio direto (PD), preparo convencional (PC) e solo nu (SN) nas profundidades em estudo.

\begin{tabular}{|c|c|c|c|c|c|c|c|c|}
\hline \multirow[t]{2}{*}{ Tratam. } & \multirow{2}{*}{$\begin{array}{l}\text { Prof. } \\
\text { (m) }\end{array}$} & \multirow{2}{*}{$\begin{array}{c}\text { Argila } \\
\left(\mathrm{kg} \mathrm{kg}^{-1}\right)\end{array}$} & \multirow{2}{*}{$\begin{array}{c}\text { Silte } \\
\left(\mathrm{kg} \mathrm{kg}^{-1}\right)\end{array}$} & \multicolumn{5}{|c|}{ Areia $\left(\mathrm{kg} \mathrm{kg}^{-1}\right)$} \\
\hline & & & & $\mathrm{AMF}^{1}$ & $\mathrm{AF}$ & AM & $A G$ & AMG \\
\hline \multirow[t]{6}{*}{$\mathrm{Gr}$} & 0,05 & 0,676 & 0,061 & 0,063 & 0,120 & 0,045 & 0,023 & 0,012 \\
\hline & 0,10 & 0,683 & 0,062 & 0,063 & 0,119 & 0,042 & 0,022 & 0,009 \\
\hline & 0,20 & 0,700 & 0,041 & 0,064 & 0,121 & 0,042 & 0,021 & 0,011 \\
\hline & 0,40 & 0,676 & 0,061 & 0,065 & 0,125 & 0,043 & 0,022 & 0,009 \\
\hline & 0,60 & 0,669 & 0,061 & 0,074 & 0,123 & 0,041 & 0,021 & 0,010 \\
\hline & 0,80 & 0,667 & 0,061 & 0,069 & 0,132 & 0,042 & 0,021 & 0,009 \\
\hline \multirow[t]{6}{*}{ PD } & 0,05 & 0,668 & 0,081 & 0,064 & 0,122 & 0,037 & 0,020 & 0,010 \\
\hline & 0,10 & 0,693 & 0,061 & 0,056 & 0,125 & 0,036 & 0,019 & 0,010 \\
\hline & 0,20 & 0,666 & 0,081 & 0,056 & 0,126 & 0,039 & 0,020 & 0,012 \\
\hline & 0,40 & 0,661 & 0,080 & 0,073 & 0,122 & 0,037 & 0,018 & 0,010 \\
\hline & 0,60 & 0,661 & 0,080 & 0,073 & 0,121 & 0,036 & 0,019 & 0,010 \\
\hline & 0,80 & 0,670 & 0,061 & 0,081 & 0,129 & 0,034 & 0,016 & 0,010 \\
\hline \multirow[t]{6}{*}{ PC } & 0,05 & 0,640 & 0,080 & 0,059 & 0,124 & 0,056 & 0,027 & 0,013 \\
\hline & 0,10 & 0,662 & 0,083 & 0,068 & 0,120 & 0,039 & 0,020 & 0,009 \\
\hline & 0,20 & 0,693 & 0,061 & 0,062 & 0,116 & 0,038 & 0,021 & 0,010 \\
\hline & 0,40 & 0,665 & 0,081 & 0,063 & 0,124 & 0,040 & 0,019 & 0,009 \\
\hline & 0,60 & 0,671 & 0,061 & 0,069 & 0,132 & 0,038 & 0,020 & 0,009 \\
\hline & 0,80 & 0,664 & 0,062 & 0,068 & 0,130 & 0,042 & 0,021 & 0,012 \\
\hline \multirow[t]{6}{*}{ SN } & 0,05 & 0,690 & 0,061 & 0,061 & 0,118 & 0,039 & 0,021 & 0,010 \\
\hline & 0,10 & 0,701 & 0,041 & 0,065 & 0,117 & 0,040 & 0,023 & 0,013 \\
\hline & 0,20 & 0,680 & 0,060 & 0,068 & 0,122 & 0,040 & 0,022 & 0,007 \\
\hline & 0,40 & 0,667 & 0,061 & 0,061 & 0,136 & 0,042 & 0,025 & 0,009 \\
\hline & 0,60 & 0,667 & 0,061 & 0,069 & 0,126 & 0,043 & 0,025 & 0,010 \\
\hline & 0,80 & 0,682 & 0,041 & 0,069 & 0,132 & 0,043 & 0,024 & 0,010 \\
\hline
\end{tabular}

${ }^{1} \mathrm{AMF}=$ areia muito fina, $\mathrm{AF}=$ areia fina, $\mathrm{AM}=$ areia média, $\mathrm{AG}=$ areia grossa, $\mathrm{AMG}=$ areia muito grossa. 


\subsection{Medições com o TDR}

\subsubsection{Calibração do TDR}

A eq. 8 mostrou ajustar-se muito bem aos pares de valores de $K_{a}-\theta\left(r^{2}>0,97\right.$ para todas as profundidades). A Tabela 3 mostra os valores dos coeficientes $a$ e $b$ dessa equação e o intervalo de confiança ao nível de probabilidade de $95 \%$ (IC) dos coeficientes para as seis profundidades avaliadas.

Tabela 3. Parâmetros de ajuste da calibração da umidade do solo em função da constante dielétrica para todas as profundidades e o intervalo de confiança dos coeficientes de ajuste.

Profundidade

Parâmetros de ajuste

\begin{tabular}{cccccc}
$(\mathrm{m})$ & $\mathrm{a}\left(\mathrm{m}^{3} \mathrm{~m}^{-3}\right)$ & $\mathrm{IC}$ para a & $\mathrm{b}\left(\mathrm{m}^{3} \mathrm{~m}^{-3}\right)$ & $\mathrm{IC}$ para b & $\mathrm{r}^{2}$ \\
\hline 0,05 & 0,688 & 0,657 a 0,719 & $-1,283$ & $-1,373 \mathrm{a}-1,193$ & 0,984 \\
0,10 & 0,676 & 0,647 a 0,704 & $-1,271$ & $-1,356 \mathrm{a}-1,187$ & 0,986 \\
0,20 & 0,677 & 0,638 a 0,715 & $-1,291$ & $-1,404 \mathrm{a}-1,178$ & 0,979 \\
0,40 & 0,664 & 0,637 a 0,691 & $-1,197$ & $-1,272 \mathrm{a}-1,122$ & 0,987 \\
0,60 & 0,640 & 0,619 a 0,661 & $-1,171$ & $-1,231 \mathrm{a}-1,110$ & 0,991 \\
0,80 & 0,651 & 0,625 a 0,677 & $-1,189$ & $-1,263 \mathrm{a}-1,114$ & 0,987 \\
\hline
\end{tabular}

Os pontos observados de $\mathrm{K}_{\mathrm{a}}-\theta$ e as curvas ajustadas na calibração estão representados na Figura 7, mostrando, mais uma vez, o bom ajuste da função, em cada profundidade avaliada.

Verifica-se que há sobreposição entre os intervalos de confiança ao nível de 95\% de probabilidade entre todas as profundidades, tanto para o parâmetro a como para o parâmetro $b$. Assim sendo, pode-se afirmar que, a esse nível de probabilidade, não há diferença entre as seis curvas de calibração. 

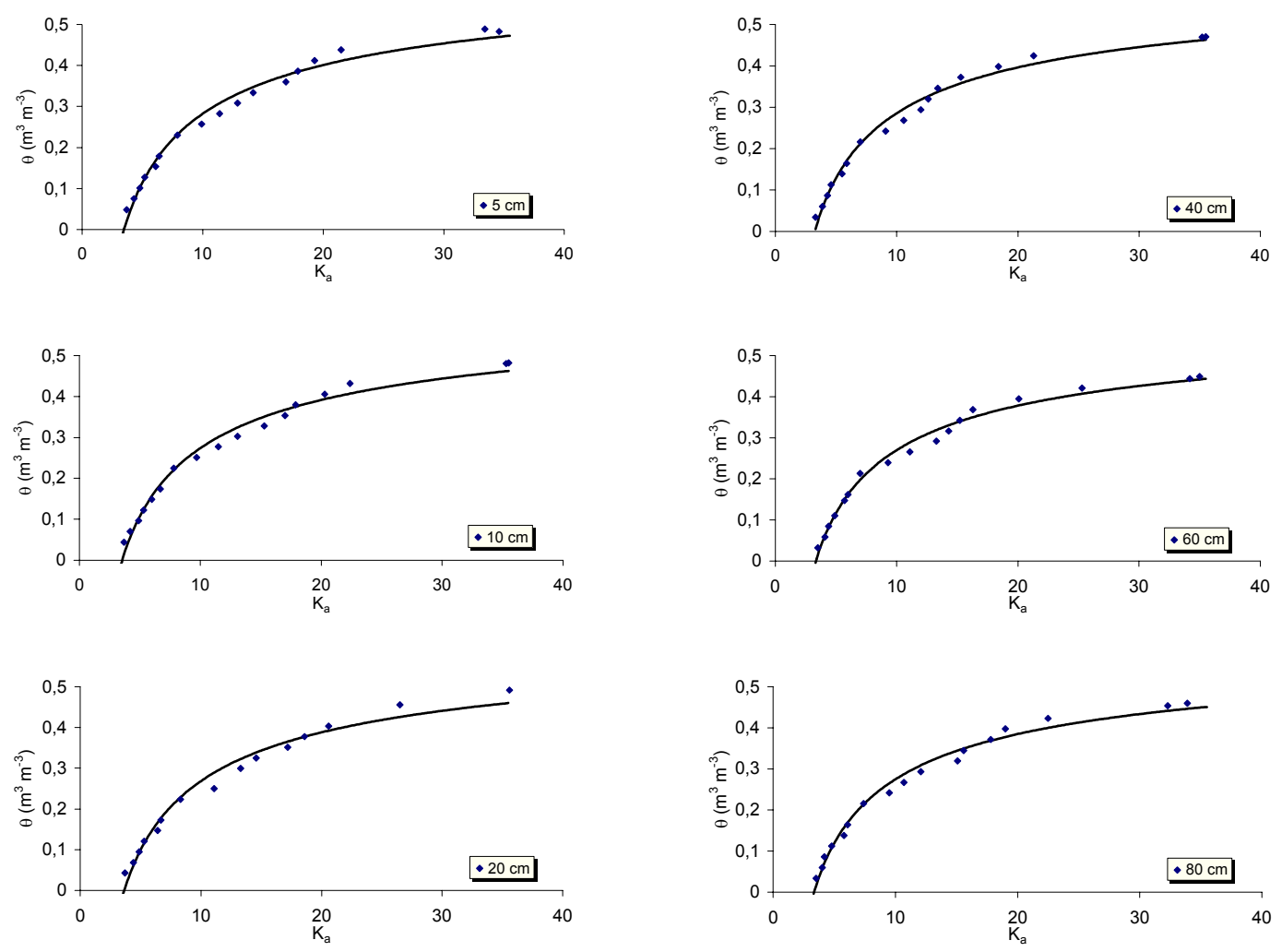

Figura 7 - Valores de $K_{a}$ em função de $\theta$ (pontos) para as profundidades $5 \mathrm{~cm}, 10 \mathrm{~cm}$, $20 \mathrm{~cm}, 40 \mathrm{~cm}, 60 \mathrm{~cm}$ e $80 \mathrm{~cm}$, conforme legenda, bem como a eq. 8 ajustada (linha sólida).

\subsubsection{Estimativa da umidade a campo}

Os valores de umidade obtidos baseando-se nas medições de $K_{a}$ do TDR e nas curvas de calibração foram utilizados como base para todas as determinações posteriores de condutividade hidráulica, fluxo, armazenagem e taxa de infiltração. Apesar do ótimo ajuste da equação de calibração aos pares de valores $\mathrm{K}_{\mathrm{a}}-\theta$ obtidos em laboratório (item 4.2.1), uma alta variação entre as medições de $K_{a}$ a campo (e, portanto, entre estimativas de $\theta$ ) nas mesmas profundidades de um mesmo tratamento, foi freqüentemente observada, colocando-se em questão se a utilização de uma única curva de calibração é adequada para todos os pontos de observação. Embora Topp et al. (1980) tenham afirmado que a calibração do TDR praticamente independe de características do solo como granulometria, mineralogia ou densidade, sabe-se que o equipamento efetua sua medição em um volume muito pequeno de 
solo, tornando-o sensível a variações naturais (ou induzidas pela inserção do equipamento) do solo.

Para exemplificar a variação ocorrida entre os valores de $\mathrm{K}_{\mathrm{a}}$ obtidos nas três repetições de cada tratamento ao longo do mês de março/2000, a Tabela 4 mostra, para as 24 combinações de tratamento e profundidade, que os coeficientes de variação médios do $\mathrm{K}_{\mathrm{a}}$ ficaram abaixo de $25 \%$ enquanto que o coeficiente de variação do coeficiente de variação ficou entre 9,15 e 59,12, indicando que a variação entre as repetições pode ter sido baixa em determinado período mas ao longo do mês foi bastante variável. As maiores variações entre os coeficientes de variação ocorreram principalmente na profundidade $0,05 \mathrm{~m}$ dos tratamentos plantio direto e preparo convencional, na profundidade $0,20 \mathrm{~m}$ do preparo convencional e na profundidade $0,60 \mathrm{~m}$ do tratamento grama apesar destes apresentarem relativamente baixos valores de coeficiente de variação médio. Observa-se também que os maiores valores médios do coeficiente de variação ocorreram na superfície do tratamento grama e nas últimas profundidades dos tratamentos plantio direto e preparo convencional. Esses coeficientes de variação são superiores aos coeficientes de variação normalmente encontrados entre umidades volumétricas de um solo. Assim, pode-se inferir que a calibração feita em laboratório não se aplica a todos os pontos de medida a campo.

Tabela 4. Coeficiente de variação médio para os valores de $\mathrm{Ka}(\overline{C V})$ no mês de março/2000 e o coeficiente de variação dos coeficientes de variação $\left(\mathrm{CV}_{\mathrm{CV}}\right)$, para cada profundidade e tratamento em estudo.

\begin{tabular}{|c|c|c|c|c|c|c|c|c|}
\hline \multirow{4}{*}{$\begin{array}{l}\text { Profundidade } \\
\qquad \text { (m) }\end{array}$} & \multicolumn{8}{|c|}{ Tratamento } \\
\hline & \multicolumn{2}{|c|}{ Grama } & \multicolumn{2}{|c|}{ Plantio direto } & \multicolumn{2}{|c|}{ Prep. convencional } & \multicolumn{2}{|c|}{ Solo nu } \\
\hline & $\overline{C V}$ & $\mathrm{CV}_{\mathrm{CV}}$ & $\overline{C V}$ & $\mathrm{CV}_{\mathrm{CV}}$ & $\overline{C V}$ & $\mathrm{CV}_{\mathrm{CV}}$ & $\overline{C V}$ & $\mathrm{CV}_{\mathrm{CV}}$ \\
\hline & \multicolumn{8}{|c|}{$(\%)$} \\
\hline 0,05 & 15,59 & 22,34 & 8,76 & 40,65 & 4,87 & 45,41 & 9,43 & 28,54 \\
\hline 0,10 & 8,82 & 31,52 & 6,07 & 30,00 & 4,08 & 20,86 & 4,10 & 27,53 \\
\hline 0,20 & 17,01 & 16,95 & 7,66 & 26,47 & 3,62 & 59,12 & 10,64 & 15,56 \\
\hline 0,40 & 7,73 & 15,75 & 5,82 & 27,03 & 7,60 & 30,21 & 6,83 & 36,14 \\
\hline 0,60 & 5,70 & 40,79 & 6,50 & 23,10 & 13,10 & 9,93 & 13,45 & 9,15 \\
\hline 0,80 & 7,38 & 38,59 & 12,26 & 14,12 & 23,53 & 8,74 & 8,51 & 13,30 \\
\hline
\end{tabular}


A variação do valor de $\theta$ observado entre as repetições, nas profundidades e tratamentos em estudo, em um determinado período (2 horas do dia 29/03/2000) pode ser vista pela Figura 8. Observa-se que somente um determinado momento não pode servir de base para a avaliação da variabilidade entre as repetições de cada profundidade pois discrepâncias nos valores de $\theta$ estimado pelo $\mathrm{K}_{\mathrm{a}}$ podem ocorrer em qualquer profundidade. Como exemplo pode-se observar a variação entre os valores de $\theta$ nas profundidades $0,40,0,60$ e $0,80 \mathrm{~m}$ do tratamento preparo convencional e na profundidade $0,60 \mathrm{~m}$ do tratamento solo nu. Nesses casos, certamente os valores dos coeficientes de variação de $\mathrm{K}_{\mathrm{a}}$ entre as repetições apresentaram-se bastante elevados, contribuindo para a variabilidade entre os valores dos coeficientes de variação em um determinado período, no entanto, especificamente neste exemplo os $\mathrm{CV}_{\mathrm{CV}}$ foram relativamente baixos $(<10 \%)$ quando comparados aos demais 20 valores, exceto na profundidade $0,60 \mathrm{~m}$ do tratamento preparo convencional em que o $\mathrm{CV}_{\mathrm{CV}}$ foi de $30 \%$.
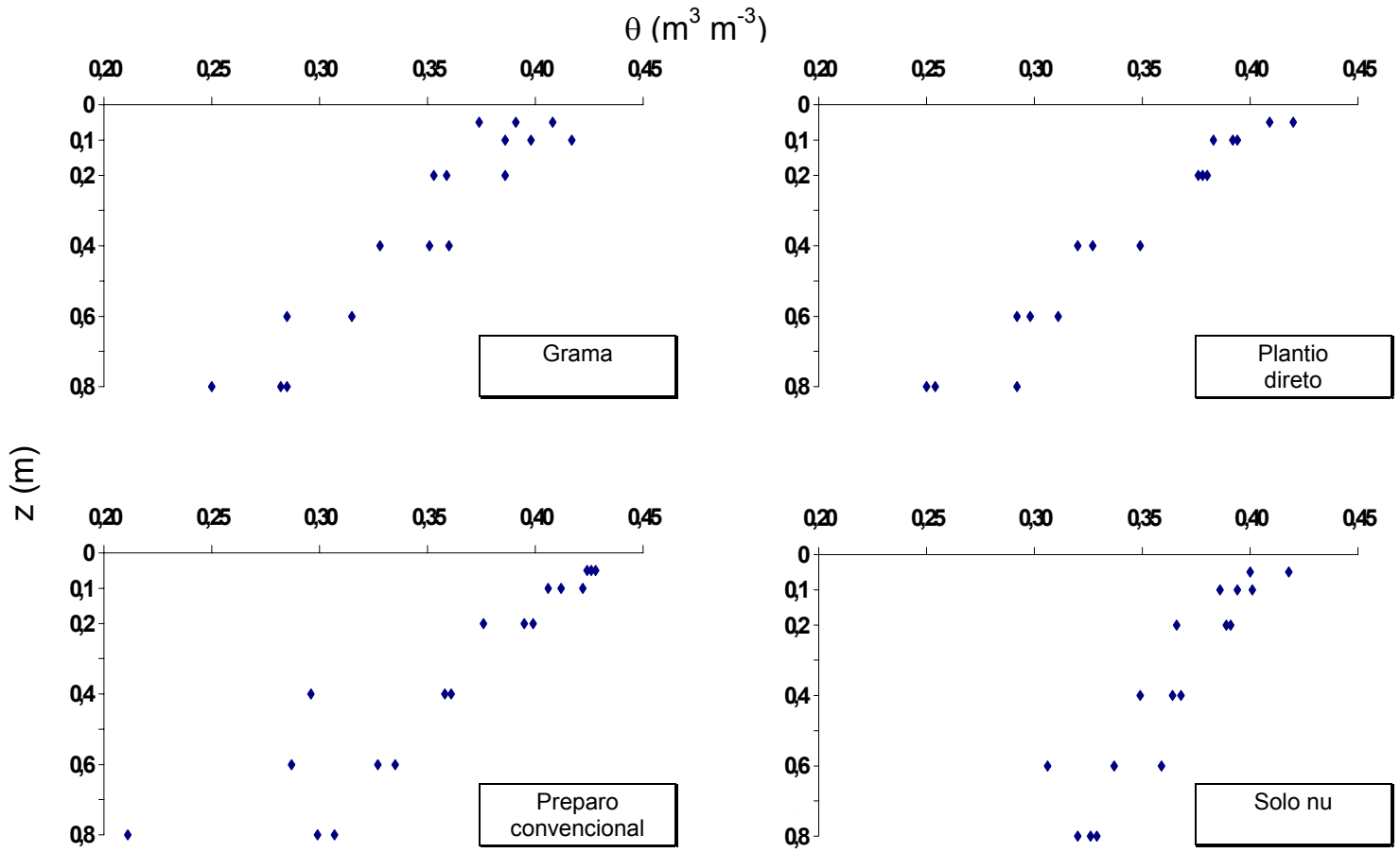

Figura 8 - Valores de $\theta$ estimados pela eq. 8, para cada ponto de observação (repetição) e profundidade em estudo, correspondentes às 2 horas do dia 29 de março de 2000. 


\subsection{Propriedades hídricas do solo}

\subsubsection{Curva de Retenção}

Os parâmetros das curvas de retenção de água no solo e o seu respectivo coeficiente de correlação, para as seis profundidades em cada ponto de observação, estão apresentados na Tabela 5 para o tratamento grama, na Tabela 6 para 0 tratamento plantio direto, na Tabela 7 para o preparo convencional e na Tabela 8 para o tratamento solo nu.

Observa-se que o coeficiente de correlação foi maior que 0,97 em todas as curvas, indicando bom ajuste. Embora os parâmetros de ajuste das curvas de retenção tenham apresentado valores bastantes variáveis, principalmente em $\alpha(0,0050$ a $\left.6,0185 \mathrm{kPa}^{-1}\right)$, as curvas apresentaram comportamentos semelhantes e valores de umidade pouco discrepantes. O fato de os cinco parâmetros $\theta_{\mathrm{r}}, \theta_{\mathrm{s}}, \alpha, \mathrm{m}$ e $\mathrm{n}$ determinarem conjuntamente o comportamento de cada curva significa que uma alteração em um dos seus parâmetros pode ser compensada pela alteração em outro, isoladamente os parâmetros não tem significado físico.

Tabela 5. Parâmetros de ajuste do modelo de van Genuchten para a descrição das curvas de retenção de água no solo no tratamento grama.

\begin{tabular}{|c|c|c|c|c|c|c|c|}
\hline \multirow{2}{*}{$\begin{array}{l}\text { Prof. } \\
\text { (m) }\end{array}$} & \multirow[t]{2}{*}{ Rep. } & \multicolumn{6}{|c|}{ Parâmetros da curva de retenção de água no solo } \\
\hline & & $\alpha\left(\mathrm{kPa}^{-1}\right)$ & $\mathrm{m}$ & $\mathrm{n}$ & $\theta_{\mathrm{r}}\left(\mathrm{m}^{3} \mathrm{~m}^{-3}\right)$ & $\theta_{\mathrm{S}}\left(\mathrm{m}^{3} \mathrm{~m}^{-3}\right)$ & $r^{2}$ \\
\hline \multirow[t]{3}{*}{0,05} & R1 & 5,6932 & 0,1406 & 1,8856 & 0,187 & 0,594 & 0,973 \\
\hline & $\mathrm{R} 2$ & 17,2355 & 0,0670 & 1,7489 & $-0,006$ & 0,593 & 0,985 \\
\hline & R3 & 0,9062 & 0,5460 & 0,7359 & 0,218 & 0,594 & 0,993 \\
\hline \multirow[t]{3}{*}{0,10} & $\mathrm{R} 1$ & 13,9562 & 0,1129 & 1,8322 & 0,161 & 0,615 & 0,994 \\
\hline & R2 & 61,3507 & 0,1141 & 1,5213 & 0,160 & 0,614 & 0,985 \\
\hline & R3 & 9,5647 & 0,1178 & 1,8452 & 0,160 & 0,615 & 0,991 \\
\hline \multirow[t]{3}{*}{0,20} & $\mathrm{R} 1$ & 0,1295 & 1,8581 & 0,5401 & 0,123 & 0,626 & 0,996 \\
\hline & $\mathrm{R} 2$ & 42,5036 & 0,1293 & 1,6377 & 0,189 & 0,626 & 0,994 \\
\hline & R3 & 0,1264 & 2,0455 & 0,4629 & 0,227 & 0,627 & 0,993 \\
\hline \multirow[t]{3}{*}{0,40} & $\mathrm{R} 1$ & 12,0765 & 0,1364 & 1,8329 & 0,156 & 0,618 & 0,981 \\
\hline & R2 & 22,6758 & 0,1033 & 1,7752 & 0,140 & 0,618 & 0,977 \\
\hline & R3 & 0,1131 & 1,8264 & 0,6154 & 0,222 & 0,617 & 0,997 \\
\hline \multirow[t]{3}{*}{0,60} & $\mathrm{R} 1$ & 6,3242 & 0,1330 & 1,8338 & 0,132 & 0,621 & 0,989 \\
\hline & R2 & 27,6453 & 0,0934 & 1,6911 & 0,097 & 0,620 & 0,987 \\
\hline & R3 & 0,0703 & 2,1161 & 0,6215 & 0,219 & 0,619 & 0,993 \\
\hline \multirow[t]{3}{*}{0,80} & $\mathrm{R} 1$ & 0,0999 & 1,8081 & 0,7754 & 0,220 & 0,617 & 0,987 \\
\hline & $\mathrm{R} 2$ & 0,2161 & 1,2479 & 0,7964 & 0,222 & 0,618 & 0,995 \\
\hline & R3 & 0,0754 & 1,7285 & 0,6261 & 0,216 & 0,618 & 0,996 \\
\hline
\end{tabular}


Tabela 6. Parâmetros de ajuste do modelo de van Genuchten para a descrição das curvas de retenção de água no solo no tratamento plantio direto.

\begin{tabular}{crrrrrrr}
\hline \multirow{2}{*}{ Prof. } & Rep. & \multicolumn{5}{c}{ Parâmetros da curva de retenção de água no solo } \\
\cline { 3 - 7 }$(\mathrm{m})$ & & $\alpha\left(\mathrm{kPa}^{-1}\right)$ & $\mathrm{m}$ & $\mathrm{n}$ & $\theta_{\mathrm{r}}\left(\mathrm{m}^{3} \mathrm{~m}^{-3}\right)$ & $\theta_{\mathrm{s}}\left(\mathrm{m}^{3} \mathrm{~m}^{-3}\right)$ & $\mathrm{r}^{2}$ \\
\hline 0,05 & $\mathrm{R} 1$ & 0,1713 & 1,3628 & 0,4952 & 0,206 & 0,612 & 0,993 \\
& R2 & 0,1682 & 1,7007 & 0,4605 & 0,217 & 0,613 & 0,989 \\
& R3 & 9,0183 & 0,1513 & 1,8202 & 0,162 & 0,613 & 0,990 \\
0,10 & R1 & 1,7513 & 0,5369 & 0,7505 & 0,192 & 0,636 & 0,995 \\
& R2 & 6,4883 & 0,1596 & 1,8380 & 0,164 & 0,636 & 0,968 \\
& R3 & 6,8899 & 0,1611 & 1,8508 & 0,166 & 0,636 & 0,992 \\
0,20 & R1 & 0,1682 & 1,5732 & 0,6075 & 0,238 & 0,615 & 0,995 \\
& R2 & 6,4128 & 0,1425 & 1,8333 & 0,170 & 0,615 & 0,988 \\
& R3 & 0,1896 & 1,3677 & 0,7000 & 0,232 & 0,614 & 0,995 \\
0,40 & R1 & 35,9633 & 0,1125 & 1,6799 & 0,136 & 0,634 & 0,992 \\
& R2 & 0,1101 & 2,0875 & 0,5390 & 0,212 & 0,634 & 0,992 \\
& R3 & 0,2487 & 1,3048 & 0,9132 & 0,227 & 0,633 & 0,985 \\
0,60 & R1 & 14,5229 & 0,1143 & 1,7844 & 0,119 & 0,637 & 0,992 \\
& R2 & 0,0907 & 2,1172 & 0,4943 & 0,202 & 0,636 & 0,988 \\
& R3 & 13,8644 & 0,1061 & 1,7901 & 0,084 & 0,637 & 0,985 \\
0,80 & R1 & 0,0622 & 2,0686 & 0,6609 & 0,219 & 0,620 & 0,980 \\
& R2 & 0,0765 & 2,0797 & 0,4965 & 0,203 & 0,622 & 0,992 \\
& R3 & 0,0693 & 2,0895 & 0,5414 & 0,199 & 0,620 & 0,972 \\
\hline
\end{tabular}

Tabela 7. Parâmetros de ajuste do modelo de van Genuchten para a descrição das curvas de retenção de água no solo no tratamento preparo convencional.

\begin{tabular}{crrrcccc}
\hline \multirow{2}{*}{ Prof. } & Rep. & \multicolumn{5}{c}{ Parâmetros da curva de retenção de água no solo } \\
\cline { 3 - 7 }$(\mathrm{m})$ & & $\alpha\left(\mathrm{kPa}^{-1}\right)$ & $\mathrm{m}$ & $\mathrm{n}$ & $\theta_{\mathrm{r}}\left(\mathrm{m}^{3} \mathrm{~m}^{-3}\right)$ & $\theta_{\mathrm{s}}\left(\mathrm{m}^{3} \mathrm{~m}^{-3}\right)$ & $\mathrm{r}^{2}$ \\
\hline 0,05 & $\mathrm{R} 1$ & 28,3456 & 0,0895 & 1,7495 & 0,146 & 0,588 & 0,993 \\
& $\mathrm{R} 2$ & 16,3976 & 0,1365 & 1,7988 & 0,182 & 0,589 & 0,994 \\
& $\mathrm{R} 3$ & 24,7268 & 0,0889 & 1,7181 & 0,08 & 0,588 & 0,997 \\
0,10 & $\mathrm{R} 1$ & 1,0601 & 0,6676 & 0,6537 & 0,222 & 0,592 & 0,995 \\
& $\mathrm{R} 2$ & 0,1478 & 1,4770 & 0,5823 & 0,217 & 0,591 & 0,994 \\
& $\mathrm{R} 3$ & 8,3884 & 0,1242 & 1,8342 & 0,162 & 0,592 & 0,962 \\
0,20 & $\mathrm{R} 1$ & 9,3731 & 0,1050 & 1,8118 & 0,142 & 0,612 & 0,992 \\
& $\mathrm{R} 2$ & 19,2712 & 0,0998 & 1,7806 & 0,162 & 0,602 & 0,986 \\
& $\mathrm{R} 3$ & 0,0928 & 1,6461 & 0,4671 & 0,208 & 0,601 & 0,986 \\
0,40 & $\mathrm{R} 1$ & 0,0510 & 2,3270 & 0,5568 & 0,225 & 0,611 & 0,994 \\
& $\mathrm{R} 2$ & 32,5668 & 0,1061 & 1,6947 & 0,150 & 0,612 & 0,992 \\
& $\mathrm{R} 3$ & 27,5148 & 0,0879 & 1,7364 & 0,093 & 0,612 & 0,989 \\
0,60 & $\mathrm{R} 1$ & 0,1121 & 1,5577 & 0,8013 & 0,211 & 0,613 & 0,965 \\
& $\mathrm{R} 2$ & 16,1264 & 0,0934 & 1,7902 & 0,103 & 0,614 & 0,991 \\
& $\mathrm{R} 3$ & 37,4200 & 0,0994 & 1,6605 & 0,116 & 0,614 & 0,986 \\
0,80 & $\mathrm{R} 1$ & 0,0520 & 1,1292 & 0,8122 & 0,222 & 0,604 & 0,985 \\
& $\mathrm{R} 2$ & 17,4067 & 0,0681 & 1,7596 & 0,015 & 0,610 & 0,981 \\
& $\mathrm{R} 3$ & 30,0856 & 0,0905 & 1,6829 & 0,090 & 0,610 & 0,988 \\
\hline
\end{tabular}


Tabela 8. Parâmetros de ajuste do modelo de van Genuchten para a descrição das curvas de retenção de água no solo no tratamento solo nu.

\begin{tabular}{crrrrrrr}
\hline \multirow{2}{*}{ Prof. } & Rep. & \multicolumn{5}{c}{ Parâmetros da curva de retenção de água no solo } \\
\cline { 3 - 7 }$(\mathrm{m})$ & & $\alpha\left(\mathrm{kPa}^{-1}\right)$ & $\mathrm{m}$ & $\mathrm{n}$ & $\theta_{\mathrm{r}}\left(\mathrm{m}^{3} \mathrm{~m}^{-3}\right)$ & $\theta_{\mathrm{s}}\left(\mathrm{m}^{3} \mathrm{~m}^{-3}\right)$ & $\mathrm{r}^{2}$ \\
\hline 0,05 & $\mathrm{R} 1$ & 10,4811 & 0,1207 & 1,8600 & 0,197 & 0,573 & 0,995 \\
& R2 & 4,9969 & 0,1352 & 1,8485 & 0,173 & 0,573 & 0,981 \\
& R3 & 0,6290 & 0,1097 & 4,4148 & 0,222 & 0,574 & 0,983 \\
0,10 & R1 & 5,4006 & 0,1674 & 1,7490 & 0,196 & 0,599 & 0,995 \\
& R2 & 0,6167 & 0,8173 & 0,6324 & 0,217 & 0,599 & 0,982 \\
& R3 & 0,2722 & 0,8810 & 0,7859 & 0,220 & 0,598 & 0,992 \\
0,20 & R1 & 0,4067 & 0,8618 & 0,9397 & 0,236 & 0,600 & 0,994 \\
& R2 & 0,2895 & 1,1942 & 0,7454 & 0,233 & 0,601 & 0,995 \\
& R3 & 0,0632 & 2,1190 & 0,5841 & 0,232 & 0,600 & 0,994 \\
0,40 & R1 & 0,9633 & 0,8752 & 0,6511 & 0,216 & 0,621 & 0,997 \\
& R2 & 0,1182 & 2,0196 & 0,5799 & 0,225 & 0,620 & 0,986 \\
& R3 & 0,0897 & 1,9843 & 0,6179 & 0,214 & 0,620 & 0,997 \\
0,60 & R1 & 0,2997 & 1,2388 & 0,5680 & 0,220 & 0,603 & 0,986 \\
& R2 & 0,1478 & 1,5526 & 0,6963 & 0,228 & 0,602 & 0,992 \\
& R3 & 0,1468 & 1,1496 & 1,0423 & 0,227 & 0,599 & 0,988 \\
0,80 & R1 & 0,6300 & 0,3286 & 1,9211 & 0,227 & 0,597 & 0,989 \\
& R2 & 0,3598 & 0,5477 & 1,5304 & 0,229 & 0,596 & 0,986 \\
& R3 & 0,1733 & 0,9341 & 1,2735 & 0,230 & 0,594 & 0,989 \\
\hline
\end{tabular}

De modo geral, verifica-se que o parâmetro $\alpha$ assumiu valores grandes $\left(>1 \mathrm{kPa}^{-1}\right)$ naquelas amostras que também resultaram em valores de $n$ maiores do que 1. Valores pequenos de $\alpha\left(<1 \mathrm{kPa}^{-1}\right)$ corresponderam a $n$ menor que 1 . É interessante notar que o próprio van Genuchten (1980) restringiu os valores de $n$ ao domínio $n>1$; no entanto, essa restrição se deveu a razões relacionadas à dependência por ele assumida entre $m$ e $n$, e que serviu ao cálculo da condutividade hidráulica relativa, não empregado nessa Tese.

O pequeno efeito da grande variação entre os parâmetros de ajuste das curvas de retenção na umidade calculada é exemplificado na Figura 9. Nessa figura mostram-se as curvas de retenção do tratamento preparo convencional na profundidade de $0,40 \mathrm{~m}$, onde as curvas apresentam-se semelhantes quando os valores de $\alpha$ (entre 0,05 e 32,7 $\mathrm{kPa}^{-1}$ ), m (entre 0,08 e 2,33 $\mathrm{kPa}^{-1}$ ) e n (entre 0,57 e $1,74 \mathrm{kPa}^{-1}$ ) e $\theta_{\mathrm{r}}$ (entre 0,093 e $0,225 \mathrm{~m}^{3} \mathrm{~m}^{-3}$ ) foram bastante variáveis (Tabela 7). Isso demonstra que, pela alteração dos parâmetros que conjuntamente determinam a curva 
de retenção, os valores de $\theta$ para dado potencial nem sempre se alteram proporcionalmente.

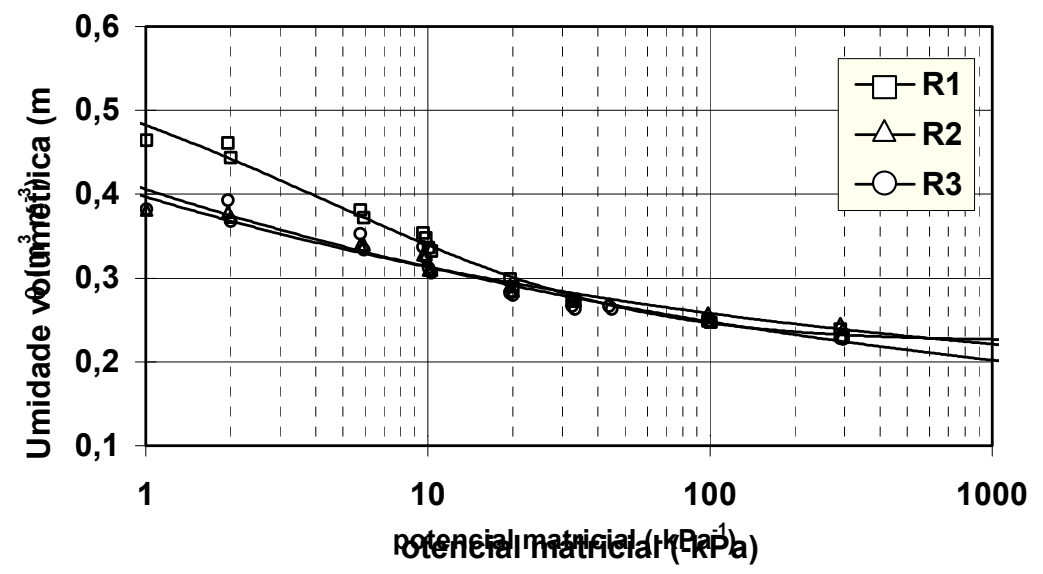

Figura 9 - Curvas de retenção de água no solo no tratamento preparo convencional, referentes às três repetições da profundidade de $40 \mathrm{~cm}$.

\subsubsection{Condutividade hidráulica do solo não saturado}

Os parâmetros de ajuste da relação $\mathrm{K}-\theta$ (eq. 13) e as faixas de umidade em que foram determinadas para cada tratamento e em cada repetição e profundidade, apresentam-se nas Tabelas 9, 10, 11 e 12. Como houve falhas ocasionais nas leituras do TDR, em alguns casos não foi possível calcular os parâmetros da relação $K(\theta)$. No caso da repetição 1 da profundidade $0,60 \mathrm{~m}$ do tratamento grama, houve falha total na leitura do sensor. Nos demais casos, valores de $\gamma$ e $\mathrm{ln} \mathrm{K}^{*}$ foram obtidos em função das observações na faixa de umidade ocorrida durante o experimento. Essa faixa oscilou entre tratamentos e repetições, na média foi da ordem de grandeza de $7 \%$ nos tratamentos grama e solo nu e 5\% nos tratamentos plantio direto e preparo convencional. $\mathrm{O}$ ajuste da eq. 13 aos valores de $\mathrm{K}-\theta$ observados resultou em altos coeficientes de determinação, todos superiores a 0,83 e a maioria acima de 0,99. Os valores de $\gamma$, que representam a taxa de decréscimo da condutividade hidráulica com o decréscimo de umidade, apresentam-se, na maioria, entre 100 e 200 e os de In K* estão, em sua maioria, entre -70 e -30 . Enfatiza-se que os valores de $\ln \mathrm{K}^{*}$ não podem ser interpretados como relativos à condutividade hidráulica do solo completamente 
seco, uma vez que representam a extrapolação dos valores de $\mathrm{K}$ observados na faixa de umidade ocorrida no experimento, longe da umidade zero. Supõe-se que o comportamento da relação In K- $\theta$ não seja uma reta quando a faixa de umidade se estende para extremos. Os valores máximos de condutividade hidráulica observados, logo após a inundação, apresentam grande variação, conforme é esperada pela grande variabilidade espacial que essa propriedade do solo normalmente exibe (Warrick \& Nielsen, 1980; Jong van Lier \& Libardi, 1999). Em diversas repetições, os valores máximos de $\mathrm{K}(\theta)$ alcançam valores da ordem de $10 \mathrm{~cm} \mathrm{~h}^{-1}$ ou mais, enquanto outras repetições tiveram valores máximos de $\mathrm{K}(\theta)$ de uma ordem de grandeza 100 vezes menor. Apenas no tratamento plantio direto observa-se a ausência dos valores máximos de $\mathrm{K}(\theta)$ da maior ordem de grandeza. As diferenças podem se dever à real variabilidade espacial da estrutura do solo mas também podem ser resultado de diferenças da umidade do solo no fim da inundação. Uma conclusão a respeito dessa questão não pode ser tirada dos dados experimentais disponíveis nesse estudo. Os valores de $K(\theta)$ referentes às menores umidades dos intervalos de determinação estão em torno de $10^{-4}$ a $10^{-5} \mathrm{~cm} \mathrm{~h}^{-1}$, sem discrepâncias. 
Tabela 9. Parâmetros de ajuste do modelo de condutividade hidráulica do solo não saturado para as profundidades em estudo nas três repetições e médias no tratamento grama e os intervalos de umidade e de $\mathrm{K}(\theta)$ ocorridos no experimento, bem como o coeficiente de correlação obtido em cada equação de ajuste.

\begin{tabular}{|c|c|c|c|c|c|c|c|}
\hline \multirow{2}{*}{$\begin{array}{l}\text { Prof. } \\
\text { (m) }\end{array}$} & \multirow[t]{2}{*}{ Rep. } & \multicolumn{2}{|c|}{$\begin{array}{c}\text { Parâmetros da } \\
\text { relação } K(\theta)\end{array}$} & \multirow{2}{*}{$\begin{array}{c}\text { Intervalo de } \\
\text { umidade }\left(\mathrm{m}^{3} \mathrm{~m}^{-3}\right) \\
\theta_{\text {máx }}-\theta_{\text {mín }}\end{array}$} & \multirow{2}{*}{$\begin{array}{c}\text { Variação } \\
\text { de } \theta \\
(\%)\end{array}$} & \multirow{2}{*}{$\begin{array}{c}\text { Intervalo de } \mathrm{K}(\theta) \\
\left(\mathrm{cm} \mathrm{h}^{-1}\right)\end{array}$} & \multirow[t]{2}{*}{$r^{2}$} \\
\hline & & $\gamma$ & $\ln \mathrm{K}^{*}$ & & & & \\
\hline \multirow[t]{4}{*}{0,05} & R1 & 129,1 & $-50,9$ & $0,407-0,322$ & 8,5 & $5,17-8,87.10^{-05}$ & 0,9998 \\
\hline & R2 & 144,8 & $-62,7$ & $0,404-0,368$ & 3,6 & $0,01-8,16 \cdot 10^{-05}$ & 0,8466 \\
\hline & R3 & 147,3 & $-63,6$ & $0,419-0,370$ & 4,9 & $0,15-1,12 \cdot 10^{-04}$ & 0,9832 \\
\hline & média & 140,4 & $-59,1$ & & & & \\
\hline \multirow[t]{4}{*}{0,10} & R1 & 184,3 & $-78,4$ & $0,417-0,378$ & 3,9 & $0,21-1,61 \cdot 10^{-04}$ & 0,9998 \\
\hline & R2 & 158,0 & $-66,7$ & $0,420-0,361$ & 5,9 & $0,71-6,37.10^{-05}$ & 0,9893 \\
\hline & R3 & 143,8 & $-60,8$ & $0,415-0,360$ & 5,5 & $0,33-1,20.10^{-04}$ & 0,9962 \\
\hline & média & 162,1 & $-68,7$ & & & & \\
\hline \multirow[t]{3}{*}{0,20} & $\begin{array}{l}\text { R1 } \\
\text { R2 }\end{array}$ & $\begin{array}{r}112,1 \\
\text { * }\end{array}$ & $\begin{array}{r}-43,9 \\
*\end{array}$ & $\underset{*}{0,405-0,320}$ & 8,5 & $4,48-3,26.10^{-04}$ & $\underset{*}{0,9998}$ \\
\hline & R3 & 141,5 & $-58,4$ & $0,409-0,350$ & 5,9 & $0,59-1,40.10^{-04}$ & 0,9994 \\
\hline & média & 126,8 & $-51,1$ & & & & \\
\hline \multirow[t]{4}{*}{0,40} & $\mathrm{R} 1$ & 112,2 & $-45,6$ & $0,418-0,337$ & 8,1 & $3,67-4,14 \cdot 10^{-04}$ & 0,9998 \\
\hline & R2 & 139,7 & $-52,3$ & $0,393-0,305$ & 8,8 & $13,49-6,18.10^{-05}$ & 0,9950 \\
\hline & R3 & 94,7 & $-37,8$ & $0,402-0,311$ & 9,1 & $1,31-2,37.10^{-04}$ & 0,9997 \\
\hline & média & 115,5 & $-45,2$ & & & & \\
\hline \multirow[t]{4}{*}{0,60} & R1 & ** & ** & ** & & & ** \\
\hline & $\mathrm{R} 2$ & 188,5 & $-52,3$ & $0,325-0,223$ & 10,2 & $7804,9-3,48.10^{-05}$ & 0,9961 \\
\hline & R3 & 107,4 & $-41,3$ & $0,376-0,301$ & 7,5 & $0,40-1,27.10^{-04}$ & 0,9995 \\
\hline & média & 147,9 & $-46,8$ & & & & \\
\hline \multirow[t]{4}{*}{0,80} & $\mathrm{R} 1$ & 107,0 & $-39,7$ & $0,364-0,295$ & 6,9 & $0,47-2,93 \cdot 10^{-04}$ & 0,9998 \\
\hline & $\mathrm{R} 2$ & 94,1 & $-34,7$ & $0,391-0,269$ & 12,2 & $8,11-8,38 \cdot 10^{-05}$ & 0,9953 \\
\hline & R3 & 105,8 & $-39,1$ & $0,359-0,287$ & 7,2 & $0,33-1,61 \cdot 10^{-04}$ & 0,9994 \\
\hline & média & 102,3 & $-37,8$ & & & & \\
\hline
\end{tabular}


Tabela 10. Parâmetros de ajuste do modelo de condutividade hidráulica do solo não saturado para as profundidades em estudo nas três repetições e médias no tratamento plantio direto e os intervalos de umidade e de $\mathrm{K}(\theta)$ ocorridos no experimento, bem como o coeficiente de correlação obtido em cada equação de ajuste.

\begin{tabular}{|c|c|c|c|c|c|c|c|}
\hline \multirow{2}{*}{$\begin{array}{l}\text { Prof. } \\
\text { (m) }\end{array}$} & \multirow[t]{2}{*}{ Rep. } & \multicolumn{2}{|c|}{$\begin{array}{c}\text { Parâmetros da } \\
\text { relação } \mathrm{K}(\theta)\end{array}$} & \multirow{2}{*}{$\begin{array}{c}\text { Intervalo de } \\
\text { umidade }\left(\mathrm{m}^{3} \mathrm{~m}^{-3}\right) \\
\theta_{\text {máx }}-\theta_{\text {mín }}\end{array}$} & \multirow{2}{*}{$\begin{array}{c}\text { Variação } \\
\text { de } \theta \\
(\%)\end{array}$} & \multirow{2}{*}{$\begin{array}{l}\text { Intervalo de } \mathrm{K}(\theta) \\
\left(\mathrm{cm} \mathrm{h}^{-1}\right) \\
\mathrm{K}\left(\theta_{\text {máx }}\right)-\mathrm{K}\left(\theta_{\text {min }}\right)\end{array}$} & \multirow[t]{2}{*}{$r^{2}$} \\
\hline & & $\gamma$ & $\ln \mathrm{K}^{*}$ & & & & \\
\hline \multirow[t]{2}{*}{0,05} & $\begin{array}{l}\mathrm{R} 1 \\
\mathrm{R} 2\end{array}$ & $\begin{array}{r}187,8 \\
*\end{array}$ & $\begin{array}{r}-83,9 \\
*\end{array}$ & $\underset{*}{0,432-0,395}$ & 3,7 & $0,06-6,01.10^{-05}$ & $\underset{*}{0,9889}$ \\
\hline & $\begin{array}{l}\text { R3 } \\
\text { média }\end{array}$ & $\begin{array}{l}141,9 \\
164,9\end{array}$ & $\begin{array}{l}-62,8 \\
-73,3\end{array}$ & $0,409-0,375$ & 3,4 & $0,01-6,86.10^{-05}$ & 0,8507 \\
\hline \multirow[t]{2}{*}{0,10} & $\begin{array}{l}\text { R1 } \\
\text { R2 }\end{array}$ & $\begin{array}{r}138,5 \\
*\end{array}$ & $\begin{array}{r}-59,8 \\
*\end{array}$ & $\begin{array}{c}0,404-0,366 \\
*\end{array}$ & 3,8 & $0,02-1,11.10^{-04}$ & $\underset{*}{0,8669}$ \\
\hline & $\begin{array}{l}\text { R3 } \\
\text { média }\end{array}$ & $\begin{array}{l}134,0 \\
136,3\end{array}$ & $\begin{array}{l}-55,5 \\
-57,6\end{array}$ & $0,394-0,346$ & 4,8 & $0,07-1,08 \cdot 10^{-04}$ & 0,8302 \\
\hline \multirow[t]{2}{*}{0,20} & $\begin{array}{l}\mathrm{R} 1 \\
\mathrm{R} 2\end{array}$ & $\begin{array}{r}96,4 \\
\text { * }\end{array}$ & $\begin{array}{r}-40,8 \\
*\end{array}$ & $\begin{array}{c}0,394-0,327 \\
*\end{array}$ & 6,7 & $0,06-9,35.10^{-05}$ & $\underset{*}{0,9935}$ \\
\hline & $\begin{array}{c}\mathrm{R3} \\
\text { média }\end{array}$ & $\begin{array}{l}122,4 \\
109,4\end{array}$ & $\begin{array}{l}-47,7 \\
-44,2\end{array}$ & $0,379-0,321$ & 5,8 & $0,27-2,23.10^{-04}$ & 0,9490 \\
\hline \multirow[t]{2}{*}{0,40} & $\begin{array}{l}\text { R1 } \\
\text { R2 }\end{array}$ & $\begin{array}{r}99,5 \\
*\end{array}$ & $\begin{array}{r}-38,1 \\
*\end{array}$ & $\begin{array}{c}0,356-0,295 \\
*\end{array}$ & 6,1 & $0,07-1,59 \cdot 10^{-04}$ & $\underset{*}{0,9941}$ \\
\hline & $\begin{array}{l}\text { R3 } \\
\text { média }\end{array}$ & $\begin{array}{l}105,5 \\
102,5\end{array}$ & $\begin{array}{l}-42,6 \\
-40,4\end{array}$ & $0,394-0,324$ & 7,0 & $0,36-2,21.10^{-04}$ & 0,9946 \\
\hline \multirow[t]{2}{*}{0,60} & $\begin{array}{l}\text { R1 } \\
\text { R2 }\end{array}$ & $\begin{array}{r}95,3 \\
*\end{array}$ & $\begin{array}{r}-36,4 \\
*\end{array}$ & $\begin{array}{c}0,343-0,287 \\
*\end{array}$ & 5,6 & $0,02-1,18.10^{-04}$ & $\underset{*}{0,9936}$ \\
\hline & $\begin{array}{l}\mathrm{R} 3 \\
\text { média }\end{array}$ & $\begin{array}{l}114,9 \\
105,1\end{array}$ & $\begin{array}{l}-43,7 \\
-40,0\end{array}$ & $0,375-0,311$ & 6,4 & $0,54-3,47.10^{-04}$ & 0,9976 \\
\hline \multirow[t]{2}{*}{0,80} & $\begin{array}{l}\text { R1 } \\
\text { R2 }\end{array}$ & $\begin{array}{r}127,9 \\
\text { * }\end{array}$ & $-41,7$ & $\begin{array}{c}0,292-0,254 \\
*\end{array}$ & 3,8 & $0,01-9,97.10^{-05}$ & $\underset{*}{0,8585}$ \\
\hline & $\begin{array}{c}\mathrm{R} 3 \\
\text { média }\end{array}$ & $\begin{array}{l}140,8 \\
134,3\end{array}$ & $\begin{array}{l}-49,1 \\
-45,4\end{array}$ & $0,336-0,292$ & 4,4 & $0,17-3,40.10^{-04}$ & 0,9937 \\
\hline
\end{tabular}


Tabela 11. Parâmetros de ajuste do modelo de condutividade hidráulica do solo não saturado para as profundidades em estudo nas três repetições e médias no tratamento preparo convencional e os intervalos de umidade e de $\mathrm{K}(\theta)$ ocorridos no experimento, bem como o coeficiente de correlação obtido em cada equação de ajuste.

\begin{tabular}{|c|c|c|c|c|c|c|c|}
\hline \multirow{2}{*}{$\begin{array}{l}\text { Prof. } \\
\text { (m) }\end{array}$} & \multirow[t]{2}{*}{ Rep. } & \multicolumn{2}{|c|}{$\begin{array}{c}\text { Parâmetros da } \\
\text { relação } \mathrm{K}(\theta)\end{array}$} & \multirow{2}{*}{$\begin{array}{c}\text { Intervalo de } \\
\text { umidade }\left(\mathrm{m}^{3} \mathrm{~m}^{-3}\right) \\
\theta_{\text {máx }}-\theta_{\text {mín }}\end{array}$} & \multirow{2}{*}{$\begin{array}{c}\text { Variação } \\
\text { de } \theta \\
(\%)\end{array}$} & \multirow{2}{*}{$\begin{array}{c}\text { Intervalo de } \mathrm{K}(\theta) \\
\left.(\mathrm{cm} \mathrm{h})^{-1}\right)\end{array}$} & \multirow[t]{2}{*}{$r^{2}$} \\
\hline & & $\gamma$ & $\ln K^{*}$ & & & & \\
\hline \multirow[t]{4}{*}{0,05} & R1 & 218,0 & $-96,0$ & $0,434-0,403$ & 3,1 & $0,25-2,90.10^{-04}$ & 0,9633 \\
\hline & R2 & 172,3 & $-79,2$ & $0,418-0,398$ & 2,0 & $0,001-2,43 \cdot 10^{-05}$ & 0,9128 \\
\hline & R3 & 181,0 & $-78,7$ & $0,441-0,391$ & 5,0 & $3,07-3,60.10^{-04}$ & 0,9989 \\
\hline & média & 190,5 & $-84,6$ & & & & \\
\hline \multirow[t]{4}{*}{0,10} & R1 & 112,7 & $-52,2$ & $0,428-0,389$ & 3,9 & $0,02-2,34.10^{-04}$ & 0,8815 \\
\hline & $\mathrm{R} 2$ & & & & & & \\
\hline & R3 & 172,1 & $-71,9$ & $0,436-0,370$ & 6,6 & $23,00-2,68.10^{-04}$ & 0,9978 \\
\hline & média & 142,4 & $-62,1$ & & & & \\
\hline \multirow[t]{4}{*}{0,20} & $\mathrm{R} 1$ & 110,4 & $-47,6$ & $0,413-0,358$ & 5,5 & $0,13-3,11 \cdot 10^{-04}$ & 0,9967 \\
\hline & $\mathrm{R} 2$ & 182,1 & $-72,5$ & $0,370-0,342$ & 2,8 & $0,01-3,64.10^{-05}$ & 0,8696 \\
\hline & R3 & 136,8 & $-57,9$ & $0,437-0,364$ & 7,3 & $6,56-3,02 \cdot 10^{-04}$ & 0,9989 \\
\hline & média & 143,1 & $-59,3$ & & & & \\
\hline \multirow[t]{4}{*}{0,40} & R1 & 86,4 & $-34,8$ & $0,397-0,313$ & 8,4 & $0,61-4,28.10^{-04}$ & 0,9999 \\
\hline & $\mathrm{R} 2$ & 129,9 & $-47,3$ & $0,318-0,284$ & 3,4 & $0,002-3,02 \cdot 10^{-05}$ & 0,8552 \\
\hline & R3 & 107,6 & $-42,3$ & $0,405-0,321$ & 8,4 & $3,59-4,26.10^{-04}$ & 0,9989 \\
\hline & média & 108,0 & $-41,5$ & & & & \\
\hline \multirow[t]{4}{*}{0,60} & R1 & 173,9 & $-67,4$ & $0,381-0,340$ & 4,1 & $0,32-2,55.10^{-04}$ & 0,9991 \\
\hline & $\mathrm{R} 2$ & 131,5 & $-48,2$ & $0,320-0,289$ & 3,1 & $0,002-3,73 \cdot 10^{-05}$ & 0,8525 \\
\hline & R3 & 107,0 & $-41,2$ & $0,390-0,313$ & 7,7 & $1,70-4,49.10^{-04}$ & 0,9989 \\
\hline & média & 137,5 & $-52,3$ & & & & \\
\hline \multirow[t]{4}{*}{0,80} & R1 & 128,7 & $-49,1$ & $0,352-0,314$ & & $0,02-1,69.10^{-04}$ & 0,9977 \\
\hline & $\mathrm{R} 2$ & 111,1 & $-35,2$ & $0,260-0,225$ & 3,5 & $0,002-3,71.10^{-05}$ & 0,8529 \\
\hline & R3 & 108,1 & $-41,3$ & $0,382-0,312$ & 7,0 & $0,99-5,14 \cdot 10^{-04}$ & 0,9989 \\
\hline & média & 116,0 & $-41,9$ & & & & \\
\hline
\end{tabular}


Tabela 12. Parâmetros de ajuste do modelo de condutividade hidráulica do solo não saturado para as profundidades em estudo nas três repetições e médias no tratamento solo nu e os intervalos de umidade e de $\mathrm{K}(\theta)$ ocorridos no experimento, bem como o coeficiente de correlação obtido em cada equação de ajuste.

\begin{tabular}{|c|c|c|c|c|c|c|c|}
\hline \multirow{2}{*}{$\begin{array}{l}\text { Prof. } \\
\text { (m) }\end{array}$} & \multirow[t]{2}{*}{ Rep. } & \multicolumn{2}{|c|}{$\begin{array}{c}\text { Parâmetros da } \\
\text { relação } \mathrm{K}(\theta)\end{array}$} & \multirow{2}{*}{$\begin{array}{c}\text { Intervalo de } \\
\text { umidade }\left(\mathrm{m}^{3} \mathrm{~m}^{-3}\right) \\
\theta_{\text {máx }}-\theta_{\text {mín }}\end{array}$} & \multirow{2}{*}{$\begin{array}{c}\text { Variação } \\
\text { de } \theta \\
(\%)\end{array}$} & \multirow{2}{*}{$\begin{array}{c}\text { Intervalo de } \mathrm{K}(\theta) \\
\left.(\mathrm{cm} \mathrm{h})^{-1}\right)\end{array}$} & \multirow[t]{2}{*}{$r^{2}$} \\
\hline & & $\gamma$ & $\ln \mathrm{K}^{*}$ & & & & \\
\hline 0,05 & $\begin{array}{c}\text { R1 } \\
\text { R2 } \\
\text { R3 } \\
\text { média }\end{array}$ & $\begin{array}{r}91,8 \\
148,5 \\
229,3 \\
156,5\end{array}$ & $\begin{array}{l}-41,4 \\
-63,2 \\
-93,6 \\
-66,1\end{array}$ & $\begin{array}{l}0,444-0,358 \\
0,416-0,359 \\
0,426-0,364\end{array}$ & $\begin{array}{l}8,6 \\
5,7 \\
6,2\end{array}$ & $\begin{array}{r}0,53-1,96 \cdot 10^{-04} \\
0,24-5,08.10^{-05} \\
59,25-3,97.10^{-05}\end{array}$ & $\begin{array}{l}0,9455 \\
0,9781 \\
0,9757\end{array}$ \\
\hline 0,10 & $\begin{array}{c}\text { R1 } \\
\text { R2 } \\
\text { R3 } \\
\text { média }\end{array}$ & $\begin{array}{l}149,1 \\
148,0 \\
201,9 \\
166,3\end{array}$ & $\begin{array}{l}-57,7 \\
-61,9 \\
-79,8 \\
-66,5\end{array}$ & $\begin{array}{l}0,350-0,329 \\
0,404-0,355 \\
0,407-0,345\end{array}$ & $\begin{array}{l}2,1 \\
4,9 \\
6,2\end{array}$ & $\begin{array}{r}0,004-1,76 \cdot 10^{-04} \\
0,12-8,61.10^{-05} \\
10,73-3,93 \cdot 10^{-05}\end{array}$ & $\begin{array}{l}0,9850 \\
0,9899 \\
0,9880\end{array}$ \\
\hline 0,20 & $\begin{array}{c}\text { R1 } \\
\text { R2 } \\
\text { R3 } \\
\text { média }\end{array}$ & $\begin{array}{l}135,8 \\
110,4 \\
172,1 \\
139,4\end{array}$ & $\begin{array}{l}-54,7 \\
-44,6 \\
-64,5 \\
-54,6\end{array}$ & $\begin{array}{l}0,411-0,339 \\
0,390-0,323 \\
0,394-0,320\end{array}$ & $\begin{array}{l}7,2 \\
6,7 \\
7,4\end{array}$ & $\begin{array}{r}3,05-1,73.10^{-04} \\
0,21-1,31.10^{-04} \\
27,31-8,04.10^{-05}\end{array}$ & $\begin{array}{l}0,9972 \\
0,9972 \\
0,9952\end{array}$ \\
\hline 0,40 & $\begin{array}{c}\text { R1 } \\
\text { R2 } \\
\text { R3 } \\
\text { média }\end{array}$ & $\begin{array}{l}105,9 \\
102,0 \\
124,9 \\
110,9\end{array}$ & $\begin{array}{l}-42,4 \\
-39,8 \\
-46,8 \\
-43,0\end{array}$ & $\begin{array}{l}0,404-0,317 \\
0,384-0,308 \\
0,398-0,301\end{array}$ & $\begin{array}{l}8,7 \\
7,6 \\
9,7\end{array}$ & $\begin{array}{r}1,47-1,46.10^{-04} \\
0,53-2,28.10^{-04} \\
18,36-1,01.10^{-04}\end{array}$ & $\begin{array}{l}0,9985 \\
0,9991 \\
0,9982\end{array}$ \\
\hline 0,60 & $\begin{array}{c}\text { R1 } \\
\text { R2 } \\
\text { R3 } \\
\text { média }\end{array}$ & $\begin{array}{r}90,5 \\
91,3 \\
104,4 \\
95,4\end{array}$ & $\begin{array}{l}-36,0 \\
-35,9 \\
-36,6 \\
-36,2\end{array}$ & $\begin{array}{l}0,413-0,309 \\
0,383-0,302 \\
0,384-0,266\end{array}$ & $\begin{array}{r}10,4 \\
8,1 \\
11,8\end{array}$ & $\begin{array}{r}3,96-3,24.10^{-04} \\
0,39-2,42.10^{-04} \\
32,77-1,46.10^{-04}\end{array}$ & $\begin{array}{l}0,9979 \\
0,9985 \\
0,9985\end{array}$ \\
\hline 0,80 & $\begin{array}{c}\text { R1 } \\
\text { R2 } \\
\text { R3 } \\
\text { média }\end{array}$ & $\begin{array}{r}81,7 \\
101,6 \\
117,8 \\
100,4\end{array}$ & $\begin{array}{l}-32,1 \\
-36,6 \\
-45,6 \\
-38,1\end{array}$ & $\begin{array}{l}0,405-0,295 \\
0,357-0,280 \\
0,403-0,310\end{array}$ & $\begin{array}{r}11,0 \\
7,7 \\
9,3\end{array}$ & $\begin{array}{l}2,69-3,36.10^{-04} \\
0,72-2,88.10^{-04} \\
6,51-1,14.10^{-04}\end{array}$ & $\begin{array}{l}0,9973 \\
0,9977 \\
0,9990\end{array}$ \\
\hline
\end{tabular}

Nas Figuras 10 e 11 visualizam-se as curvas de ajuste nos tratamentos e profundidades estudadas nas suas faixas de determinação. Observa-se que o comportamento dentro de cada profundidade é bastante variável entre as repetições, no entanto, as variações mais marcantes ocorreram nas profundidades de 5 e $60 \mathrm{~cm}$ do tratamento grama e na profundidade $80 \mathrm{~cm}$ dos tratamentos plantio direto e preparo convencional. 
grama
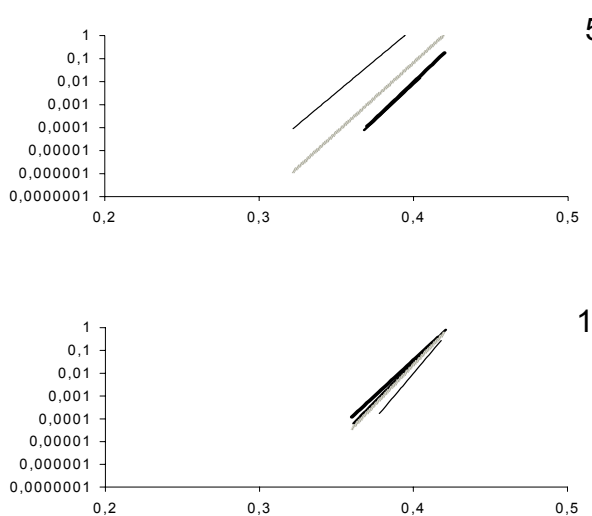

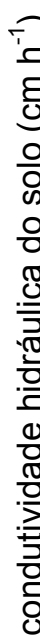
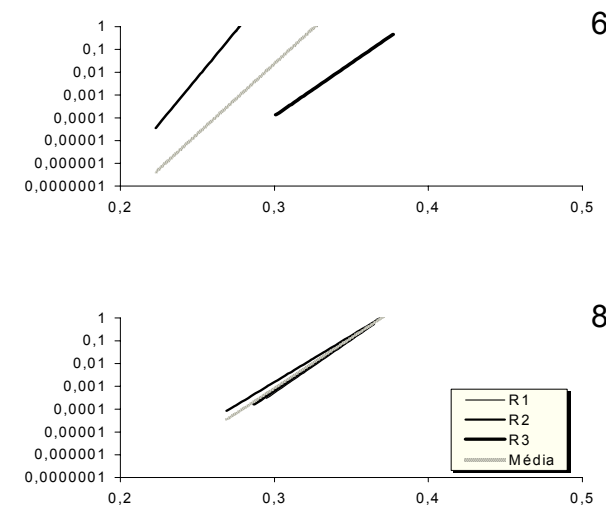

plantio direto

$5 \mathrm{~cm}$

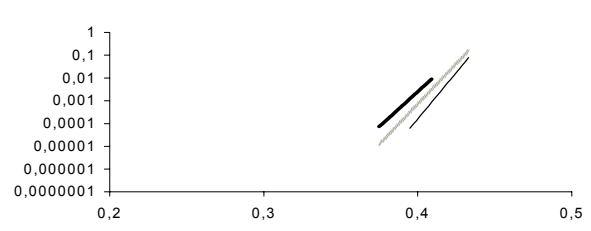

$10 \mathrm{~cm}$

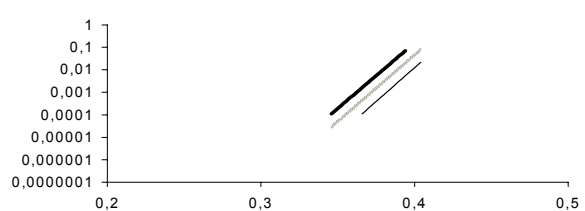

$20 \mathrm{~cm}$

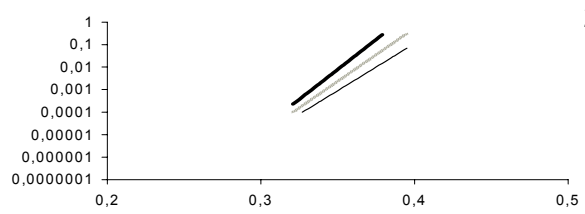

$40 \mathrm{~cm}$

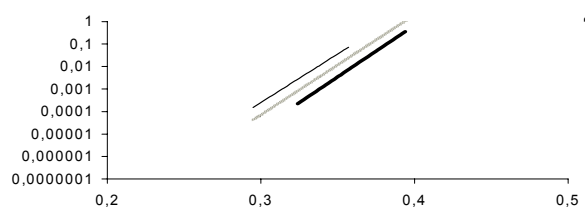

$60 \mathrm{~cm}$

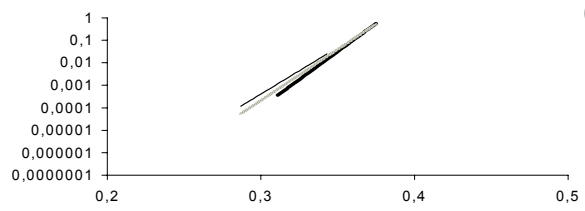

$80 \mathrm{~cm}$

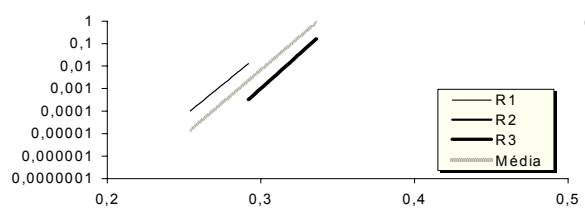

umidade do solo $\left(\mathrm{m}^{3} \mathrm{~m}^{-3}\right)$

Figura 10 - Condutividade hidráulica em função da umidade do solo, para cada repetição e profundidade $(5 \mathrm{~cm}, 10 \mathrm{~cm}, 20 \mathrm{~cm}, 40 \mathrm{~cm}, 60 \mathrm{~cm}$ e $80 \mathrm{~cm})$, na faixa de determinação e suas médias logarítmicas nos tratamentos grama e plantio direto. 
preparo convencional
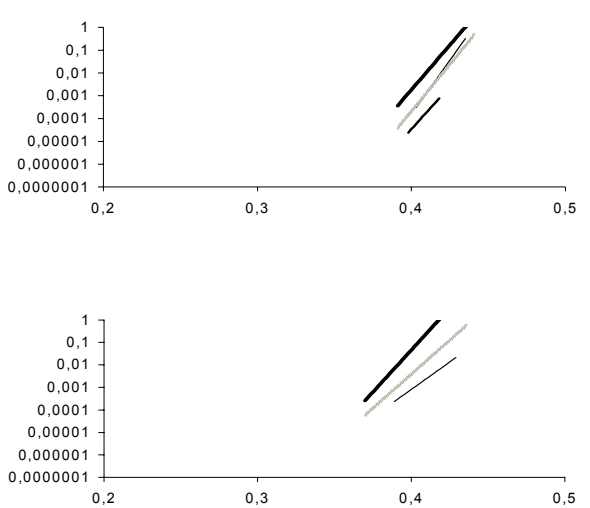

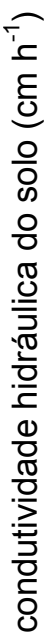
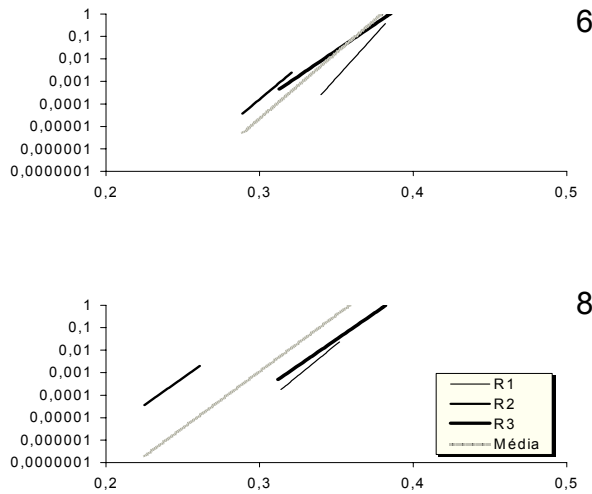

solo nu

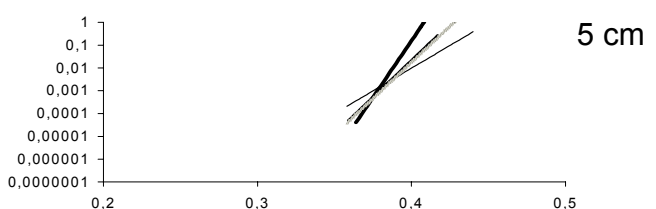

$10 \mathrm{~cm}$

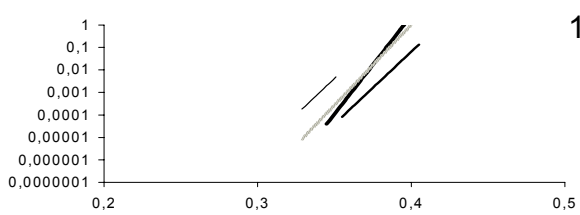

$20 \mathrm{~cm}$

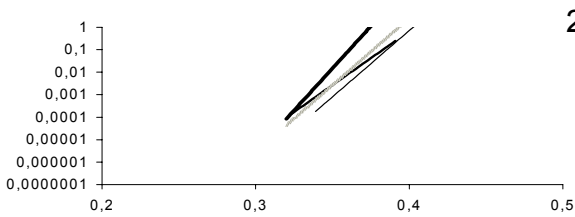

$40 \mathrm{~cm}$

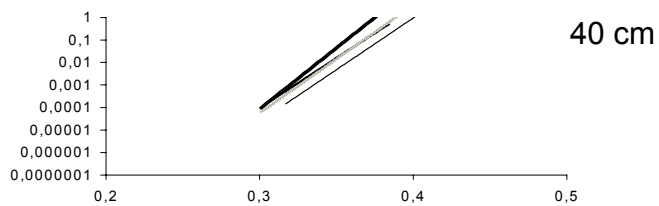

$60 \mathrm{~cm}$

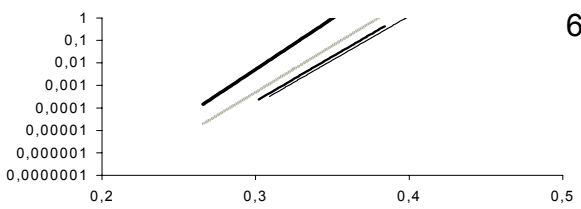

$60 \mathrm{~cm}$

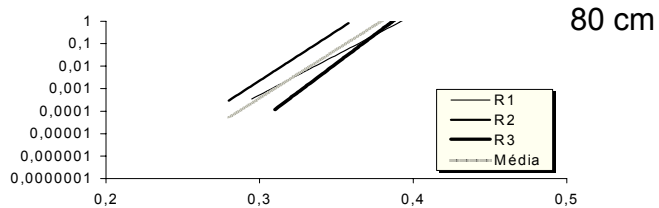

umidade do solo $\left(\mathrm{m}^{3} \mathrm{~m}^{-3}\right)$

Figura 11 - Condutividade hidráulica em função da umidade do solo, para cada repetição e profundidade $(5 \mathrm{~cm}, 10 \mathrm{~cm}, 20 \mathrm{~cm}, 40 \mathrm{~cm}, 60 \mathrm{~cm}$ e $80 \mathrm{~cm})$, na faixa de determinação e suas médias logarítmicas nos tratamentos preparo convencional e solo nu. 
O grau de incerteza na estimativa de $\mathrm{K}$, mesmo dentro de um único tratamento, pode ser demonstrada ajustando-se a eq. 13 a todos os pares de dados de $\mathrm{K}$ e $\theta$ observados nas três repetições de cada tratamento. Nesses casos, os valores de $r^{2}$ se tornam baixos para vários casos em função da variação entre repetições, (Tabela 13). Dentre todos os 24 ajustes, apenas dois apresentaram $r^{2}>0,9$, enquanto em oito casos o $r^{2}$ ficou inferior a 0,5 .

Tabela 13. Parâmetros de ajuste da equação de condutividade hidráulica em função da umidade do solo (eq. 13), utilizando todos os pares de dados de $\mathrm{K}$ e $\theta$ obtidos em cada profundidade nas três repetições, bem como o coeficiente de correlação obtido em cada equação de ajuste, para os tratamentos grama, plantio direto, preparo convencional e solo nu.

\begin{tabular}{|c|c|c|c|c|}
\hline \multirow[t]{2}{*}{ Tratamento } & \multirow{2}{*}{$\begin{array}{l}\text { Prof. } \\
\text { (m) }\end{array}$} & \multicolumn{3}{|c|}{ Parâmetros para ajuste de $K(\theta)$} \\
\hline & & $\mathrm{K}^{*}\left(\mathrm{~cm} \mathrm{~h}^{-1}\right)$ & $\gamma$ & $r^{2}$ \\
\hline \multirow[t]{6}{*}{ Grama } & 0,05 & $1,3113.10^{-21}$ & 105,2 & 0,4540 \\
\hline & 0,10 & $9,6888.10^{-22}$ & 114,0 & 0,2589 \\
\hline & 0,20 & $5,1285.10^{-15}$ & 78,1 & 0,3727 \\
\hline & 0,40 & $1,2525.10^{-16}$ & 90,2 & 0,8203 \\
\hline & 0,60 & $1,2534.10^{-16}$ & 95,9 & 0,8751 \\
\hline & 0,80 & $1,1360.10^{-18}$ & 117,1 & 0,5166 \\
\hline \multirow[t]{6}{*}{ Plantio direto } & 0,05 & $8,2484 \cdot 10^{-22}$ & 106,7 & 0,2920 \\
\hline & 0,10 & $2,8368.10^{-21}$ & 104,7 & 0,0493 \\
\hline & 0,20 & $5,6270.10^{-22}$ & 114,2 & 0,7743 \\
\hline & 0,40 & $9,1762 \cdot 10^{-15}$ & 80,3 & 0,9222 \\
\hline & 0,60 & $1,3924.10^{-18}$ & 105,4 & 0,8168 \\
\hline & 0,80 & $4,1369.10^{-19}$ & 110,8 & 0,9457 \\
\hline \multirow[t]{6}{*}{ Preparo convencional } & 0,05 & $1,1291.10^{-21}$ & 111,8 & 0,1512 \\
\hline & 0,10 & $1,1701.10^{-21}$ & 112,6 & 0,7791 \\
\hline & 0,20 & $3,1319 \cdot 10^{-18}$ & 97,0 & 0,4166 \\
\hline & 0,40 & $2,6456.10^{-17}$ & 93,8 & 0,8380 \\
\hline & 0,60 & $8,5156.10^{-17}$ & 95,4 & 0,8876 \\
\hline & 0,80 & $1,1078.10^{-15}$ & 92,3 & 0,9723 \\
\hline \multirow[t]{6}{*}{ Solo nu } & 0,05 & $7,9574.10^{-18}$ & 88,4 & 0,7718 \\
\hline & 0,10 & $1,2334.10^{-19}$ & 102,5 & 0,4327 \\
\hline & 0,20 & $5,9481 \cdot 10^{-19}$ & 103,3 & 0,7770 \\
\hline & 0,40 & $8,8723 \cdot 10^{-16}$ & 86,9 & 0,5873 \\
\hline & 0,60 & $1,6271.10^{-13}$ & 73,1 & 0,6525 \\
\hline & 0,80 & $8,4766 \cdot 10^{-14}$ & 76,1 & 0,8147 \\
\hline
\end{tabular}




\subsection{Regime pluviométrico}

Dentro do período de observação, os maiores volumes e intensidades de chuva ocorreram de dezembro de 2000 a janeiro de 2001, período correspondente à segunda safra de cultivo de milho, sendo abril de 2000 o mês de menor ocorrência de chuvas (Figuras 12 e 13). A chuva total de fevereiro de 2000 foi de 127,3 mm (média normal: 188,4); em março, 103,1 mm (média normal: 159,6); em abril, 0,5 mm (média normal: 76,4); em dezembro, 181,4 mm (média normal: 196,7); e em janeiro de 2001, 202,4 mm (média normal: 220,1).

Quanto aos meses de março e dezembro de 2000, que serão utilizados em discussão posterior, observa-se que o mês de março caracterizou-se por uma estiagem nos seus primeiros dias, interrompida por algumas chuvas de pequeno volume em 1, 7 e 17/03. Chuvas maiores ocorreram somente a partir de 21/03, acumulando um volume maior que $90 \mathrm{~mm}$. No mês de dezembro, ocorreram várias chuvas distribuídas mais uniformemente ao longo do mês. Neste mês destacam-se as chuvas de 04/12 (31,5 mm), 16-17/12 (58,7 mm) e 27-29/12 (35,8 mm), juntas acumularam quase $200 \mathrm{~mm}$. 

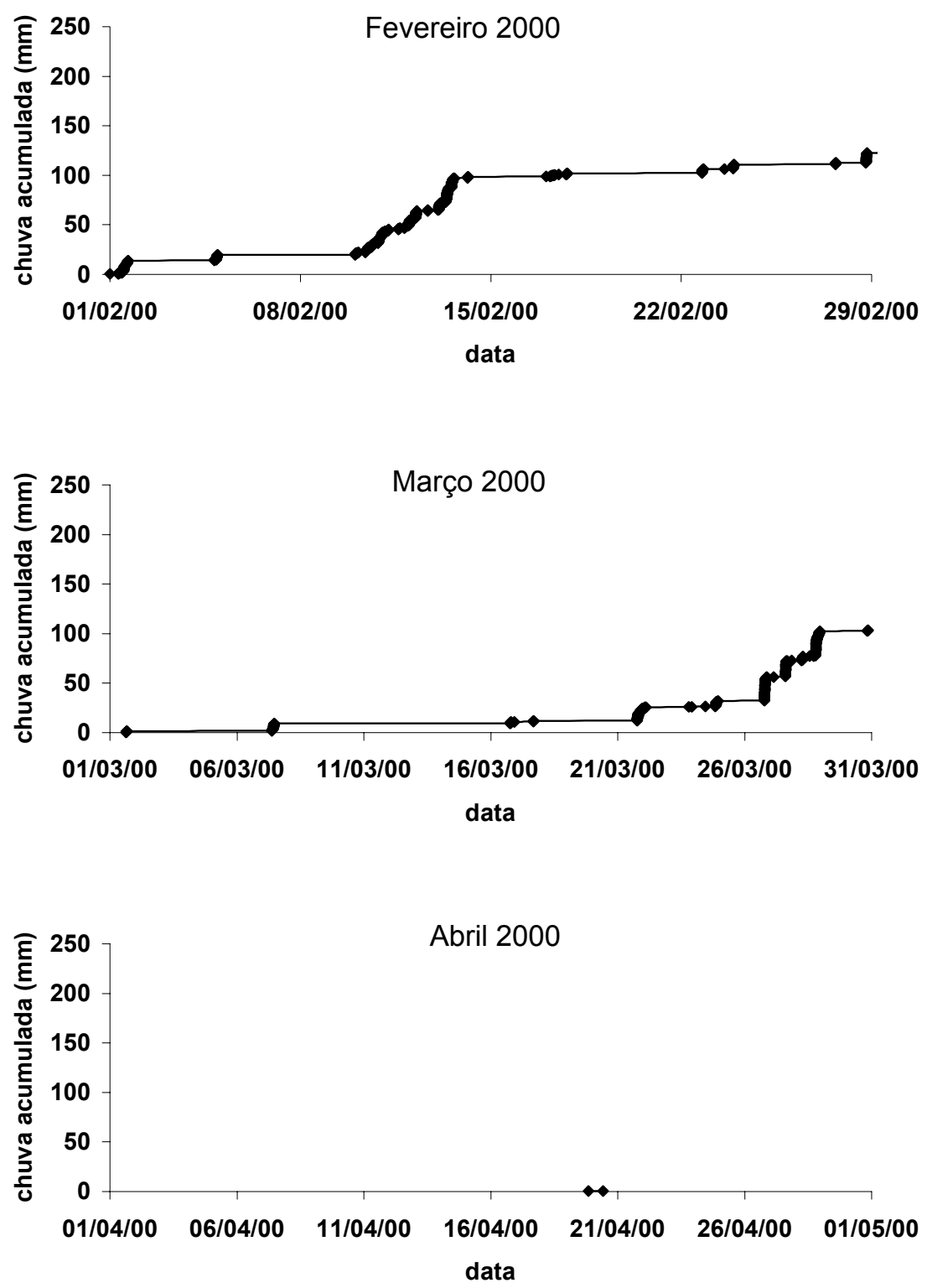

Figura 12 - Lâmina de chuva acumulada $(\mathrm{mm})$ nos meses de fevereiro a abril de 2000 , correspondente ao $1^{\circ}$ período de condução do experimento. 

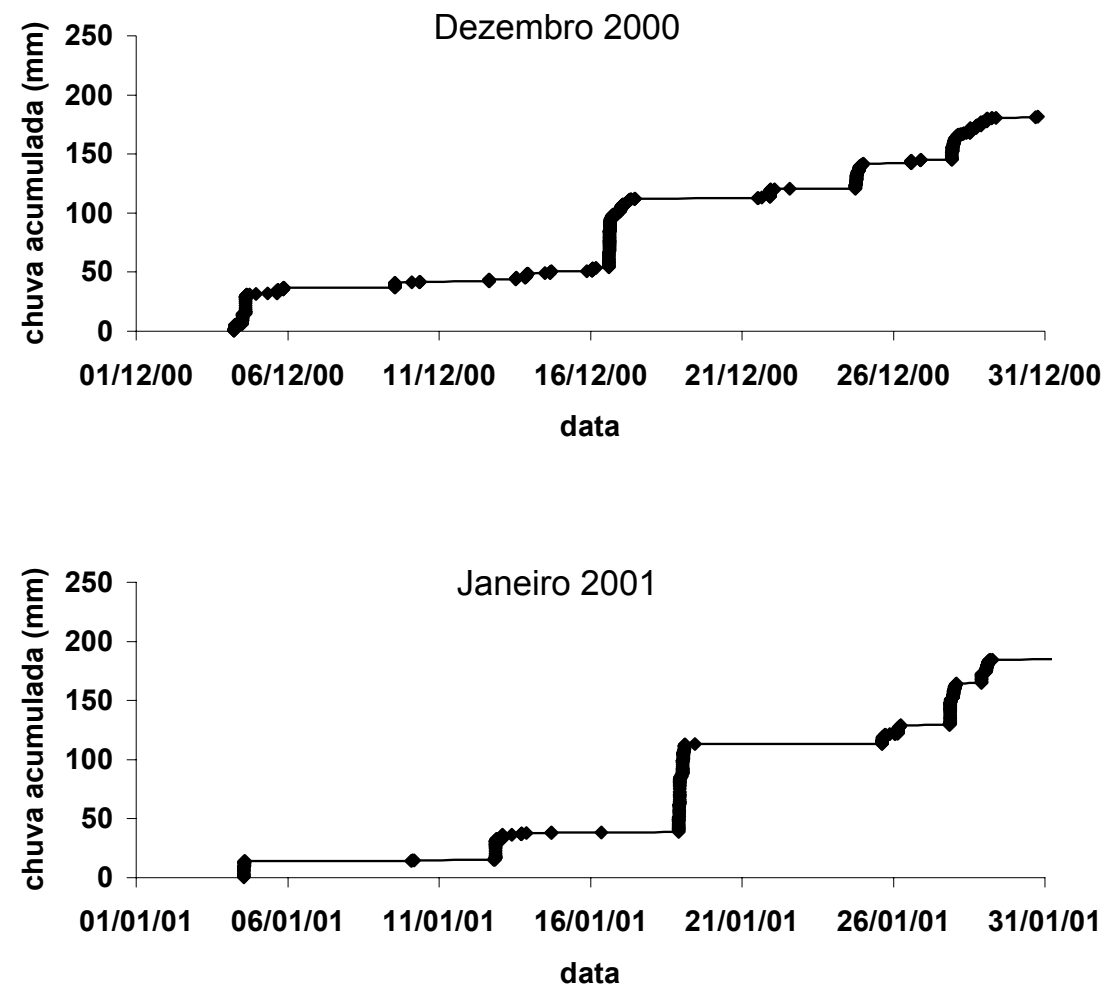

Figura 13 - Lâmina de chuva acumulada $(\mathrm{mm})$ nos meses de dezembro de 2000 e janeiro de 2001, correspondente ao $2^{\circ}$ período de condução do experimento.

\subsection{Erosão do solo}

\subsubsection{Perda de solo}

No primeiro período de cultivo, as perdas de solo foram computadas a partir do mês de março devido à instalação tardia das estacas de medida (item 3.3.8), não significando que no mês de fevereiro as perdas foram nulas. Considerando o mês de março como representativo do primeiro ano de cultivo, pode-se atribuir que dentre os tratamentos, o solo nu apresentou a maior perda de solo, seguido do preparo convencional e do plantio direto (Figura 14). Pode-se esperar que esta diferença se deveu à influência da cobertura vegetal. No início do período, todos os tratamentos apresentaram uma pequena perda de solo após uma chuva de alta intensidade e curta 
duração (07/03). No entanto, durante este período, a quantidade de solo perdida pelos tratamentos foi pequena e a diferença entre eles, não significativa. Observa-se, também, nesse período, que as coberturas vegetais sobre os tratamentos ainda não estavam bem estabelecidas e o solo encontrava-se em condições semelhantes de preparo, o que explicaria tal comportamento da perda de solo. A próxima chuva erosiva ocorreu em 22/03. Até essa data já houve um aumento gradual da massa vegetativa dos tratamentos com presença de cobertura vegetal, principalmente no tratamento grama, que auxiliou na redução das perdas de solo pela redução do impacto direto das gotas da chuva sobre o solo e por servir de obstáculo mecânico ao livre escoamento da água. Além disso, possivelmente as culturas melhoraram a estrutura superficial do solo, reduzindo a erodibilidade e facilitando a infiltração de água da chuva. Ao final do mês de março, os tratamentos grama, plantio direto e preparo convencional apresentaram um pequeno acréscimo na perda de solo, sendo que, dentre esses tratamentos, o maior acréscimo ocorreu no preparo convencional. Nesse tratamento observou-se o aparecimento de um sulco formado, provavelmente, pela maior erodibilidade proporcionada pela maior movimentação de solo no momento do preparo (Figura 15) e pela baixa cobertura vegetal sobre o mesmo. O tratamento solo nu apresentou sempre um maior acréscimo da perda de solo em relação aos demais tratamentos estudados, porém, ao final do período, após as maiores chuvas e, conseqüentemente, em condições de incidência de chuva em solo muito úmido, os valores foram ainda maiores devido à grande exposição do solo à ação da chuva e enxurrada pela ausência de cobertura vegetal. A presença de chuvas consecutivas, embora de pequeno volume, aumenta a umidade do solo, reduz sua capacidade de infiltração instantânea e aumenta o risco de enxurradas e de erosão. Estes fatos proporcionaram o aparecimento de vários sulcos na direção do canal do terraço do tratamento solo nu, que aceleraram ainda mais o processo erosivo pela concentração da energia cisalhante da enxurrada. 


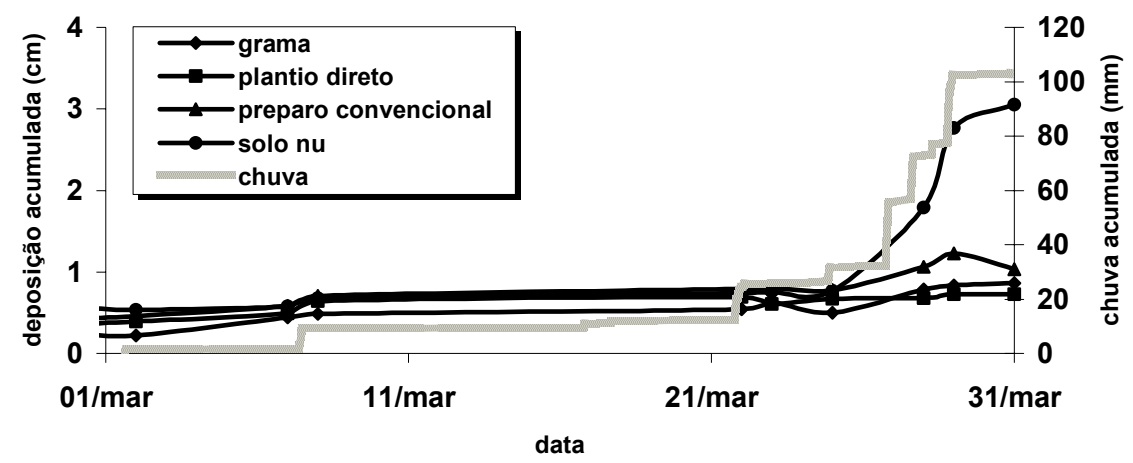

Figura 14 - Deposição acumulada de solo $(\mathrm{cm})$ a partir de fev/2000 para o mês de março (primeiro ano de cultivo de milho) nos tratamentos grama, plantio direto, preparo convencional e solo nu, bem como a chuva acumulada no mês.

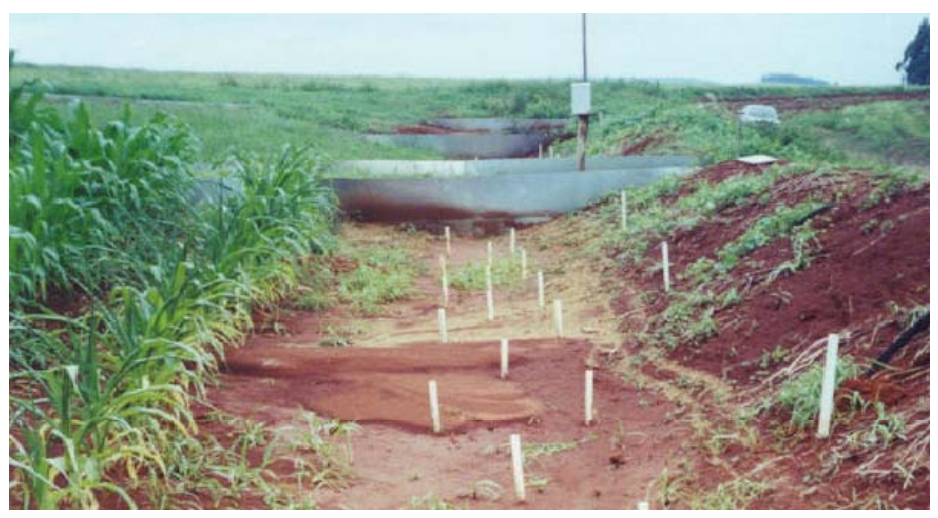

Figura 15 - Deposição de material erodido sobre o canal do terraço do preparo convencional após o aparecimento de um sulco.

No segundo ano de cultivo o acréscimo na perda de solo dos tratamentos preparo convencional e solo nu foi ainda maior do que no mês de março, como pode ser observado pelas Figuras 16 e 17. No entanto, as perdas de solo que ocorreram nos tratamentos grama e plantio direto foram praticamente nulas. A maior cobertura vegetal estabelecida nesses tratamentos auxiliou ainda mais na redução do acréscimo da perda de solo, notadamente no tratamento grama. Dentre os tratamentos com presença de cobertura vegetal, o preparo convencional apresentou um grande aumento nas perdas de solo em relação aos demais (grama e plantio direto), provavelmente devido à maior susceptibilidade do solo pela grande movimentação de 
solo no momento do preparo e a desproteção do mesmo à ação de forças erosivas da chuva e enxurrada pela contínua presença de uma baixa cobertura vegetal. $O$ tratamento solo nu, apesar do continuo e elevado acréscimo nas perdas de solo ao longo mês, as taxas tornaram-se decrescentes.

Por meio das Figuras 14, 16 e 17 pode-se transformar a altura de perda de

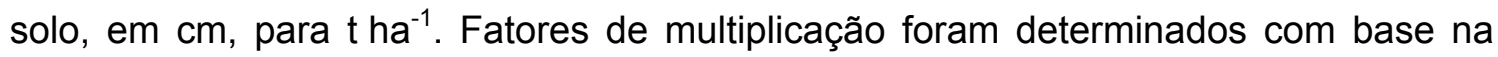
estimativa da densidade do material depositado sobre o canal do terraço $\left(1000 \mathrm{~kg} \mathrm{~m}^{-3}\right)$ e da área de captação (variável de um ano para outro no tratamento solo nu, conforme descrito no item 3.3.10) e considerando uma área total para captação da chuva em cada tratamento como sendo igual a $800 \mathrm{~m}^{2}$. Para a Figura 14 utiliza-se o fator 1,2 nos tratamentos grama, plantio direto e preparo convencional e o fator 3,0 no tratamento solo nu. Já no segundo ano de cultivo (Figura 16), o fator 1,2 continua sendo utilizado nos tratamentos grama, plantio direto e preparo convencional enquanto que para o solo nu deve-se utilizar o fator 3,6.

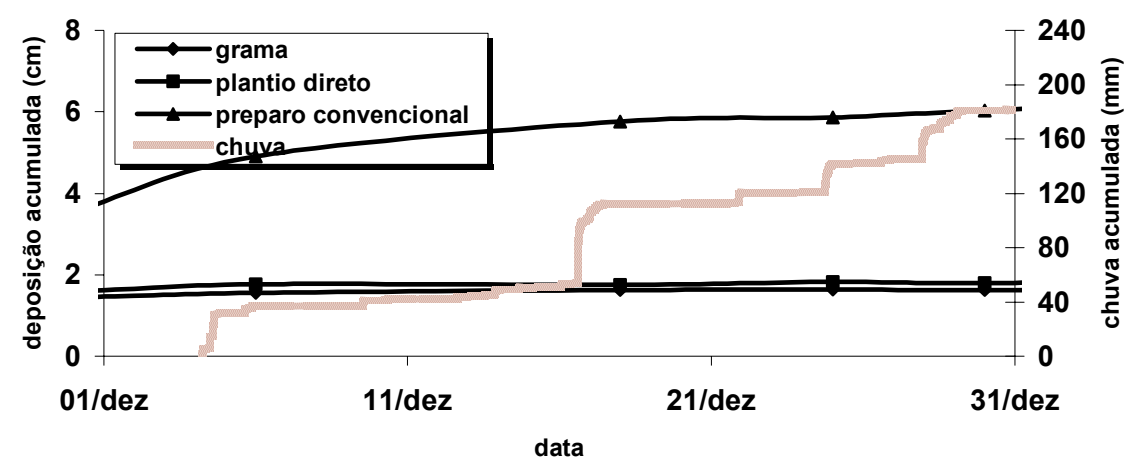

Figura 16 - Deposição acumulada de solo $(\mathrm{cm})$ a partir de fev/2000 para o mês de dezembro (segundo ano de cultivo de milho) nos tratamentos grama, plantio direto e preparo convencional, bem como a chuva acumulada no mês. 


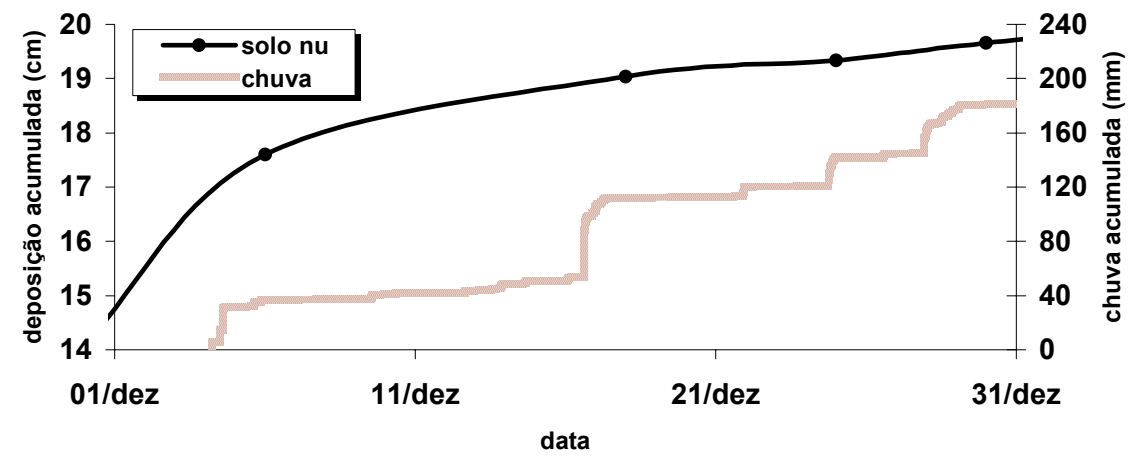

Figura 17 - Deposição acumulada de solo (cm) a partir de fev/2000 para o mês de dezembro (segundo ano de cultivo de milho) no tratamento solo nu, bem como a chuva acumulada no mês.

\subsubsection{Granulometria do material erodido}

A granulometria do material depositado no canal do terraço durante o primeiro e segundo ano de cultivo não apresentou diferença significativa entre os tratamentos plantio direto, preparo convencional e solo nu em relação à granulometria da superfície do solo de cada tratamento (Tabela 14). No entanto, algumas diferenças foram encontradas no tratamento grama, possivelmente devido à deposição de material introduzido com as placas de grama quando na sua implantação.

Salienta-se que essas granulometrias são valores médios para o material depositado sobre o canal. Observaram-se grandes variações na deposição do material tanto no sentido vertical (estratificação) como no sentido horizontal (Figura 18), principalmente no tratamento solo nu.
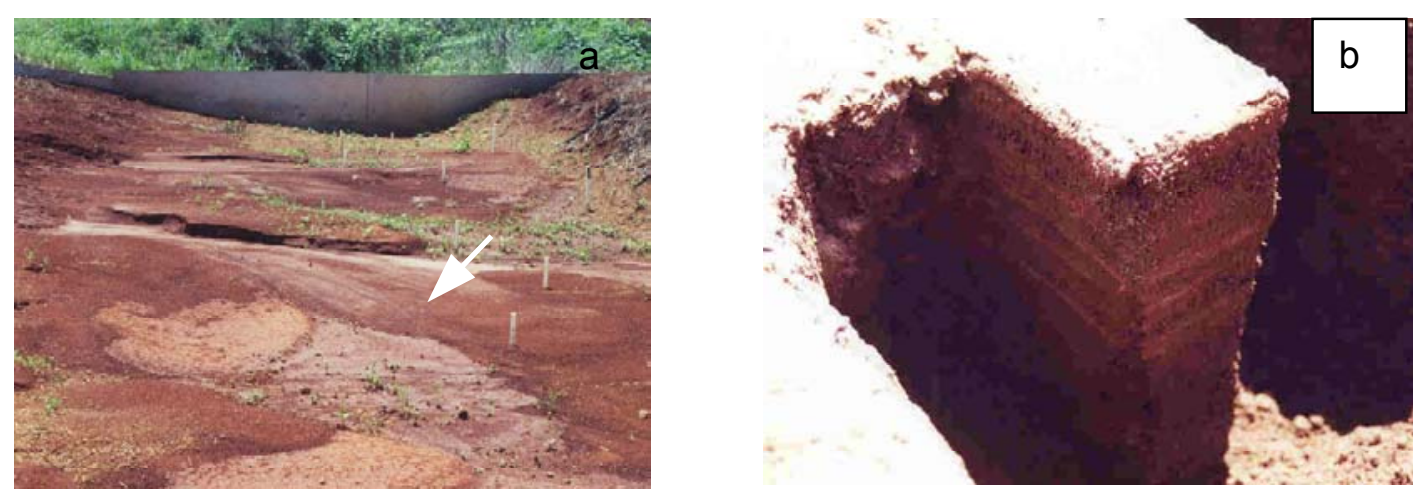

Figura 18 - Deposição de solo sobre o canal do terraço do tratamento solo nu (a) com detalhe da estratificação (b). 
Estudos micromorfológicos, não realizados para esta Tese, poderiam descrever e quantificar esta estratificação, que certamente tem uma influência sobre a capacidade de infiltração do terraço.

Tabela 14. Granulometria média da superfície do solo nos tratamentos grama, plantio direto, preparo convencional e solo nu e do material depositado sobre o canal do terraço (média de cinco repetições).

\begin{tabular}{|c|c|c|c|c|c|c|c|}
\hline \multirow[t]{2}{*}{ Local de coleta } & \multirow{2}{*}{$\begin{array}{c}\text { Argila } \\
\left(\mathrm{kg} \mathrm{kg}^{-1}\right)\end{array}$} & \multirow{2}{*}{$\begin{array}{c}\text { Silte } \\
\left(\mathrm{kg} \mathrm{kg}^{-1}\right)\end{array}$} & \multicolumn{5}{|c|}{ Areia $\left(\mathrm{kg} \mathrm{kg}^{-1}\right)$} \\
\hline & & & $\mathrm{AMF}^{1}$ & $\mathrm{AF}$ & AM & $A G$ & AMG \\
\hline & & & & Grama & & & \\
\hline Superfície do solo & $0,52 A^{2}$ & $0,11 \mathrm{~A}$ & $0,10 \mathrm{~B}$ & $0,15 \mathrm{~B}$ & $0,07 \mathrm{~A}$ & $0,03 \mathrm{AB}$ & $0,01 \mathrm{~A}$ \\
\hline Deposição $1^{\circ}$ ano & $0,68 \mathrm{~B}$ & $0,10 \mathrm{~A}$ & $0,06 \mathrm{~A}$ & $0,10 \mathrm{~A}$ & $0,04 \mathrm{~A}$ & $0,01 \mathrm{~A}$ & $0,01 \mathrm{~A}$ \\
\hline \multirow[t]{2}{*}{ Deposição $2^{\circ}$ ano } & $0,61 \mathrm{~A}$ & $0,08 \mathrm{~A}$ & $0,06 \mathrm{~A}$ & $0,14 \mathrm{~B}$ & $0,06 \mathrm{~A}$ & $0,03 \mathrm{~B}$ & $0,01 \mathrm{~A}$ \\
\hline & \multicolumn{7}{|c|}{ Plantio Direto } \\
\hline Superfície do solo & $0,58 \mathrm{~A}$ & $0,11 \mathrm{~A}$ & $0,07 \mathrm{~A}$ & $0,14 \mathrm{~A}$ & $0,06 \mathrm{~A}$ & $0,02 \mathrm{~A}$ & $0,02 \mathrm{~A}$ \\
\hline Deposição $1^{\circ}$ ano & $0,64 \mathrm{~A}$ & $0,08 \mathrm{~A}$ & $0,06 \mathrm{~A}$ & $0,13 \mathrm{~A}$ & $0,06 \mathrm{~A}$ & $0,02 \mathrm{~A}$ & $0,01 \mathrm{~A}$ \\
\hline \multirow[t]{2}{*}{ Deposição $2^{\circ}$ ano } & $0,64 \mathrm{~A}$ & $0,07 \mathrm{~A}$ & $0,06 \mathrm{~A}$ & $0,14 \mathrm{~A}$ & $0,05 \mathrm{~A}$ & $0,02 \mathrm{~A}$ & $0,01 \mathrm{~A}$ \\
\hline & \multicolumn{7}{|c|}{ Preparo Convencional } \\
\hline Superfície do solo & $0,62 \mathrm{~A}$ & $0,11 \mathrm{~A}$ & $0,07 \mathrm{~A}$ & $0,13 \mathrm{~A}$ & $0,05 \mathrm{~A}$ & $0,02 \mathrm{~A}$ & $0,01 \mathrm{~A}$ \\
\hline Deposição $1^{\circ}$ ano & $0,73 \mathrm{~A}$ & $0,07 \mathrm{~A}$ & $0,06 \mathrm{~A}$ & $0,09 \mathrm{~A}$ & $0,03 \mathrm{~A}$ & $0,01 \mathrm{~A}$ & $0,01 \mathrm{~A}$ \\
\hline \multirow[t]{2}{*}{ Deposição $2^{\circ}$ ano } & $0,70 \mathrm{~A}$ & $0,10 \mathrm{~A}$ & $0,05 \mathrm{~A}$ & $0,09 \mathrm{~A}$ & $0,03 \mathrm{~A}$ & $0,02 \mathrm{~A}$ & $0,01 \mathrm{~A}$ \\
\hline & \multicolumn{7}{|c|}{ Solo Nu } \\
\hline Superfície do solo & $0,59 \mathrm{~A}$ & $0,08 \mathrm{~A}$ & $0,07 \mathrm{~A}$ & $0,15 \mathrm{~A}$ & $0,06 \mathrm{~A}$ & $0,03 \mathrm{~A}$ & $0,01 \mathrm{~A}$ \\
\hline Deposição $1^{\circ}$ ano & $0,67 \mathrm{~A}$ & $0,10 \mathrm{~A}$ & $0,05 \mathrm{~A}$ & $0,11 \mathrm{~A}$ & $0,04 \mathrm{~A}$ & $0,02 \mathrm{~A}$ & $0,01 \mathrm{~A}$ \\
\hline Deposição $2^{\circ}$ ano & $0,68 \mathrm{~A}$ & $0,08 \mathrm{~A}$ & $0,05 \mathrm{~A}$ & $0,11 \mathrm{~A}$ & $0,04 \mathrm{~A}$ & $0,02 \mathrm{~A}$ & $0,01 \mathrm{~A}$ \\
\hline
\end{tabular}

\subsection{Movimento sub-superficial de água no solo}

O movimento de água no solo foi avaliado pelos valores da densidade de fluxo calculados pela eq. 14. Como os valores de condutividade hidráulica utilizados foram os calculados pela eq. 13, cujos parâmetros apresentaram grande variabilidade conforme discutido em item anterior, pode-se esperar uma incerteza grande na densidade de fluxo calculada. Essa constatação se reforça considerando que o gradiente de potencial total da eq. 14 foi calculado baseando-se em umidades 
(estimadas pelas leituras do TDR) transformadas em potenciais matriciais. Dessa forma, valores discrepantes de densidade de fluxo podem ser esperados, o que se confirmou em alguns casos, como mostram as Figuras 19, 20, 21 e 22 para os três meses do $1^{\circ}$ ano de cultivo e as Figuras 23 e 24 para o $2^{\circ}$ ano de cultivo. Espera-se, por exemplo, que logo após uma chuva, a densidade de fluxo descendente seja, em módulo, maior na superfície e diminuindo gradualmente em profundidade devido à armazenagem das camadas superiores. Em alguns casos, os valores observados mostram exatamente isso, por exemplo, no tratamento solo nu em fevereiro de 2000 (Figura 19). Em outros casos, discrepâncias esperadas se confirmam. Como exemplo, na mesma figura, o tratamento preparo convencional apresentou uma densidade de fluxo observada na camada de 5-10 cm inferior a da camada de $10-20 \mathrm{~cm}$ e $20-40 \mathrm{~cm}$ logo após o período de chuva entre os dias 10 e 13/02/2000.

Ainda na Figura 19 observa-se que as maiores densidades de fluxo ocorreram logo após as chuvas de maior intensidade (10 a 13/02/2000), principalmente, no tratamento solo nu seguido pelos tratamentos preparo convencional e plantio direto, os quais apresentaram pouca diferença entre si. A maior densidade de fluxo de água no canal do terraço do tratamento solo nu deve-se, provavelmente, ao fato da maior presença de deposição de água sobre o canal proveniente da maior enxurrada proporcionada, principalmente, pela redução da infiltração de água pela área a montante do terraço devido à formação do selo superficial do solo pela ausência de cobertura vegetal.

No mês de março observa-se que as densidades de fluxo mantiveram-se semelhantes às densidades de fluxo apresentadas no mês de fevereiro porém, chuvas de maior intensidade, essenciais para a avaliação das diferenças entre as densidades de fluxo de cada tratamento, ocorreram somente ao final do período. Este fato faz com que as maiores alterações das densidades de fluxo entre os tratamentos ocorressem, principalmente, nesse período (Figura 20). No tratamento grama ocorreu a presença de densidade de fluxo da água com sentido ascendente na camada de 5-10 cm, logo após as chuvas do fim deste mês. Essa observação pode se dever aos problemas mencionados anteriormente, mas pode também ser devido à deposição de solo sobre um ou mais locais de observação devido a desmoronamentos do camalhão sobre a superfície do local onde se encontrava(m) a(s) bateria(s) de sensores no canal do 
terraço deste tratamento. Segundo o artigo Terraceamento planejado garante controle da erosão (1968), este fato é comum no primeiro até terceiro ano após a construção de terraços, dependendo do tipo de solo, pois a terra que constitui o camalhão ainda não se consolidou. Com relação aos demais tratamentos, as densidades de fluxo continuaram apresentando-se em valores mais elevados no tratamento solo nu porém, em dimensões ainda maiores. Isso pode dever-se à maior umidade antecedente do solo na área experimental e à contínua exposição deste solo úmido à ação da chuva, permitindo o aumento gradativo do selamento superficial, com conseqüente redução da taxa de infiltração, aumento de enxurrada sobre a área e deposição de um grande volume de água sobre o canal deste tratamento. A maior capacidade de infiltração se confirma também pelas variações nos valores de densidade de fluxo das camadas mais superficiais do tratamento solo nu após a pequena chuva do dia $08 / 03$, enquanto que nos demais tratamentos esta chuva praticamente não causou alterações. As diferenças encontradas entre as densidades de fluxo dos tratamentos preparo convencional e plantio direto tornaram-se mais nítidas, provavelmente, devido ao aparecimento de um sulco observado no preparo convencional, facilitando as perdas de solo e água. O melhor estabelecimento da cobertura vegetal sobre o solo no plantio direto em relação ao preparo convencional, também, deve ter auxiliado nas reduções das perdas de solo e água da área desse tratamento.

Durante o mês de abril, praticamente não ocorreram chuvas (chuva acumulada de 0,5 mm). A ausência de chuvas erosivas permitiu que as densidades de fluxo se tornassem quase nulas ou ligeiramente positivos (fluxo ascendente) em todos os tratamentos até o fim do mês (Figura 21).

Na Figura 22 apresentam-se os valores de densidade de fluxo, detalhados de 30 em 30 minutos, para o período de 27/03 a 04/04 de 2000. Nesse período, várias chuvas maiores e mais intensas ocorreram. Verifica-se nesse detalhe, especialmente nos tratamentos plantio direto e preparo convencional, que a frente de molhamento, ocorrida devido à chuva do dia 29/03, atingiu as camadas mais profundas (40-60 e 60$80 \mathrm{~cm}$ ) com defasagem de 1 a 2 dias. Verifica-se, também, que a densidade de fluxo calculada para as camadas mais superficiais (5-10 e de 10-20 cm) mostra-se com muito mais variação em pequenos intervalos de tempo. 


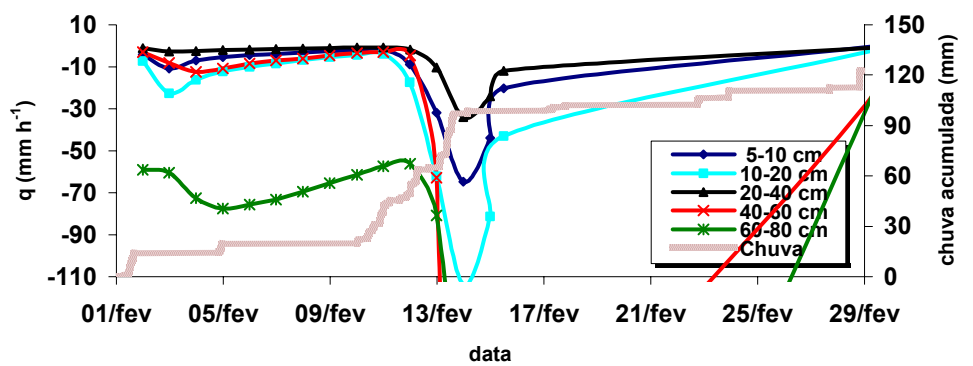

Grama

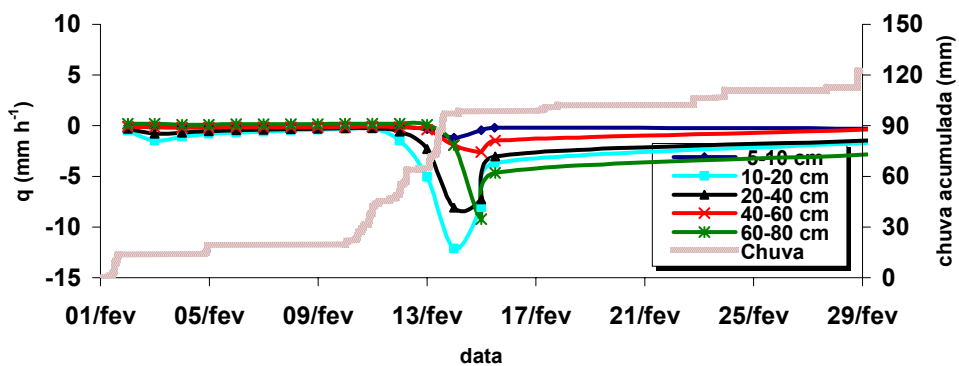

Plantio

direto

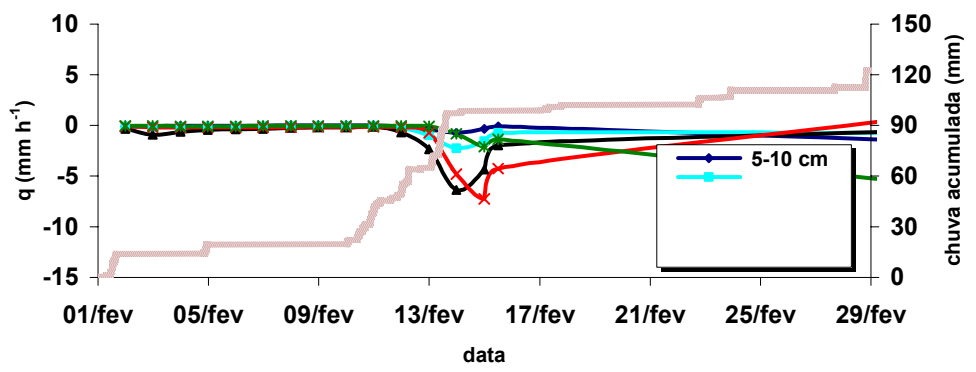

Preparo

convencional

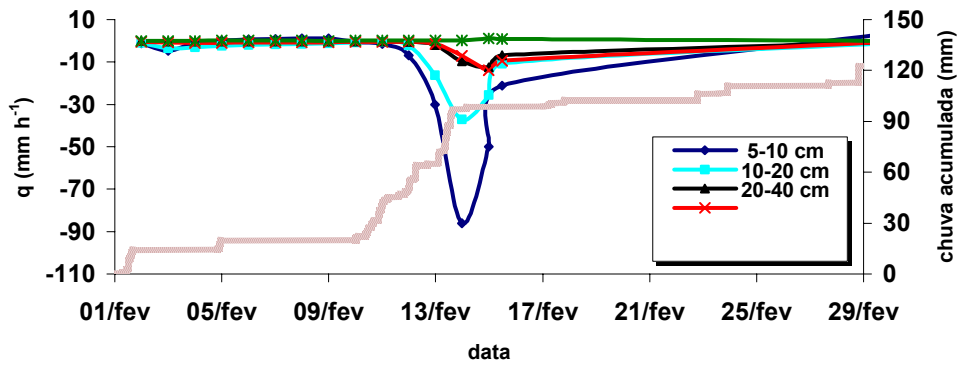

Solo nu

Figura 19 - Média diária da densidade de fluxo de água no solo (q, $\mathrm{mm} \mathrm{h}^{-1}$ ) nos tratamentos grama, plantio direto, preparo convencional e solo nu, para as camadas de 5 a $10 \mathrm{~cm}, 10$ a $20 \mathrm{~cm}, 20$ a $40 \mathrm{~cm}, 40$ a $60 \mathrm{~cm}$ e de 60 a $80 \mathrm{~cm}$ e chuva acumulada no mês de fevereiro de 2000 . 


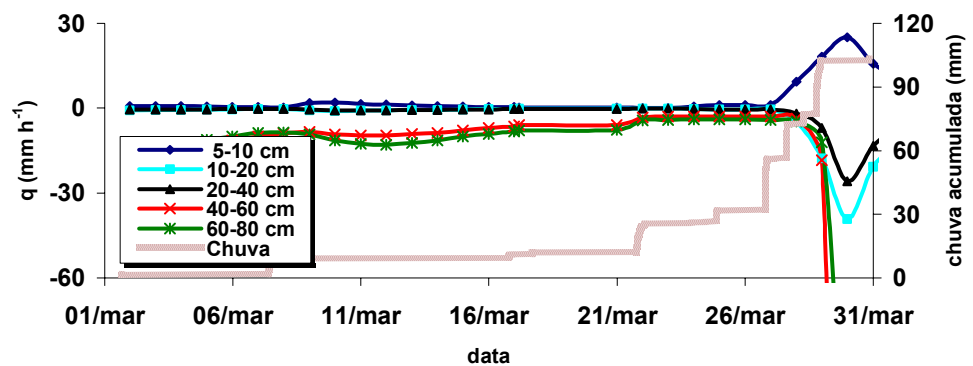

Grama

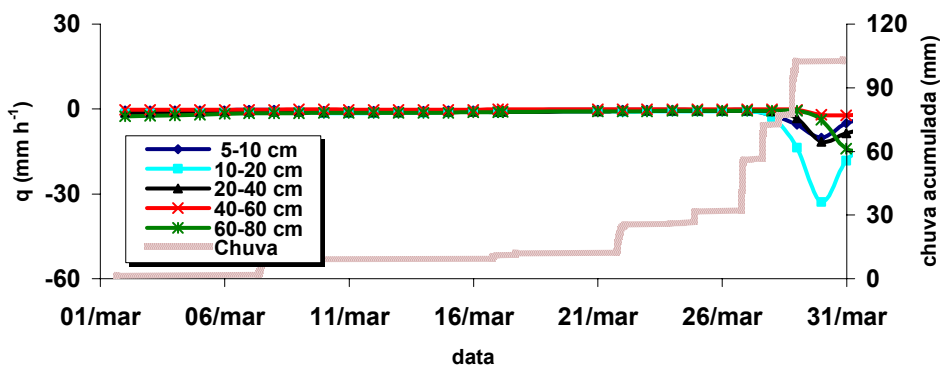

Plantio

direto

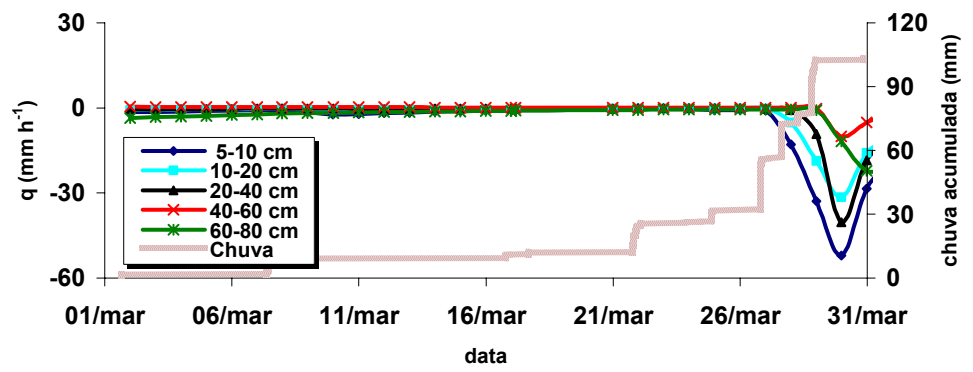

Preparo

convencional

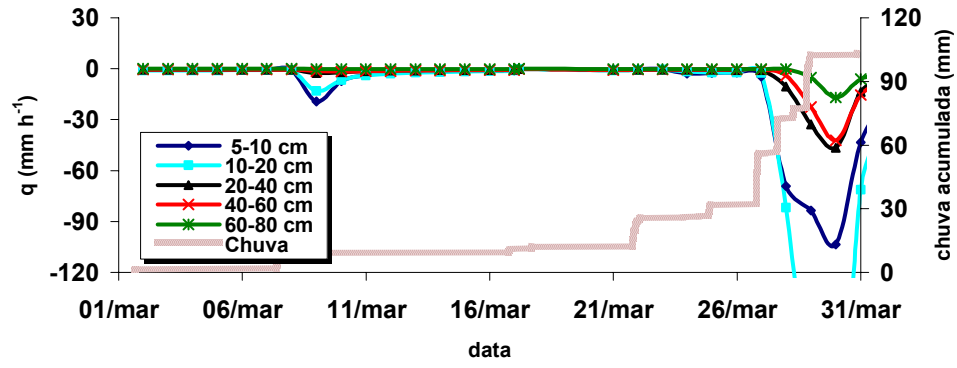

Solo nu

Figura 20 - Média diária da densidade de fluxo de água no solo (q, $\mathrm{mm} \mathrm{h}^{-1}$ ) nos tratamentos grama, plantio direto, preparo convencional e solo nu, para as camadas de 5 a $10 \mathrm{~cm}, 10$ a $20 \mathrm{~cm}, 20$ a $40 \mathrm{~cm}, 40$ a $60 \mathrm{~cm}$ e de 60 a $80 \mathrm{~cm}$ e chuva acumulada no mês de março de 2000. 


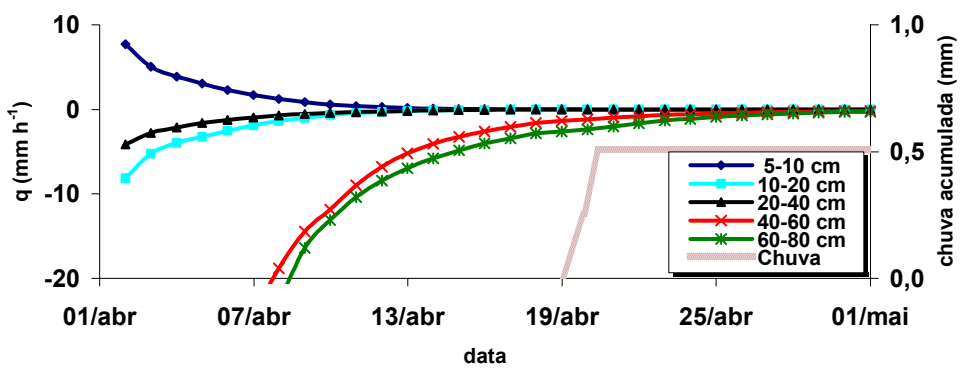

Grama

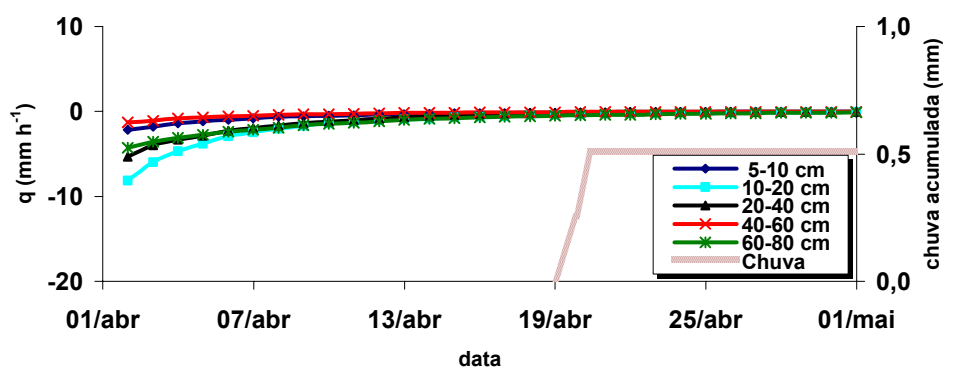

Plantio

direto

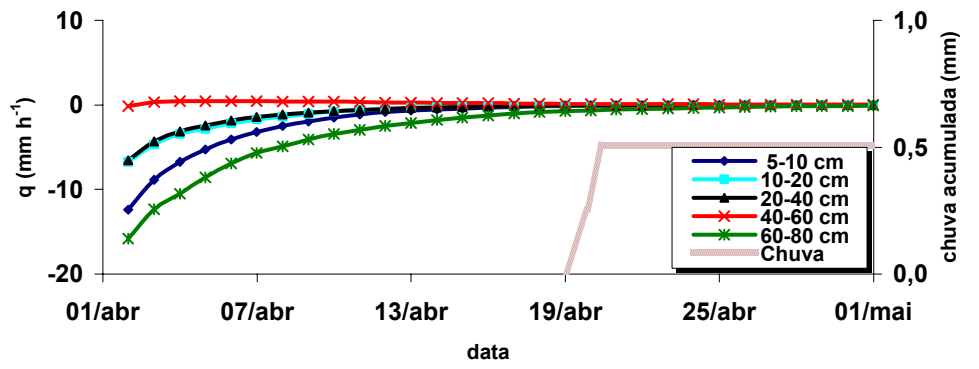

Preparo

convencional

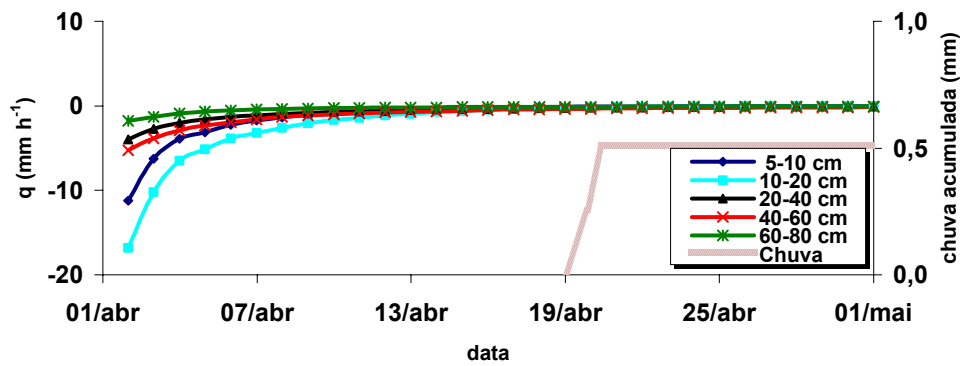

Solo nu

Figura 21 - Média diária da densidade de fluxo de água no solo (q, $\mathrm{mm} \mathrm{h}^{-1}$ ) nos tratamentos grama, plantio direto, preparo convencional e solo nu, para as camadas de 5 a $10 \mathrm{~cm}, 10$ a $20 \mathrm{~cm}, 20$ a $40 \mathrm{~cm}, 40$ a $60 \mathrm{~cm}$ e de 60 a $80 \mathrm{~cm}$ e chuva acumulada no mês de abril de 2000 . 


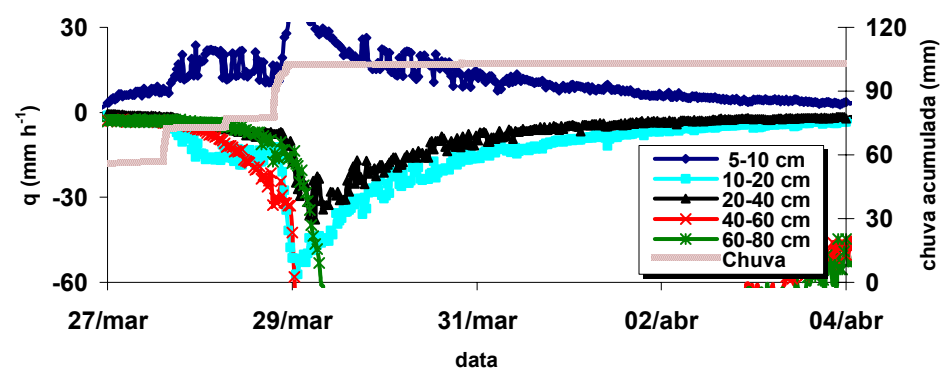

Grama

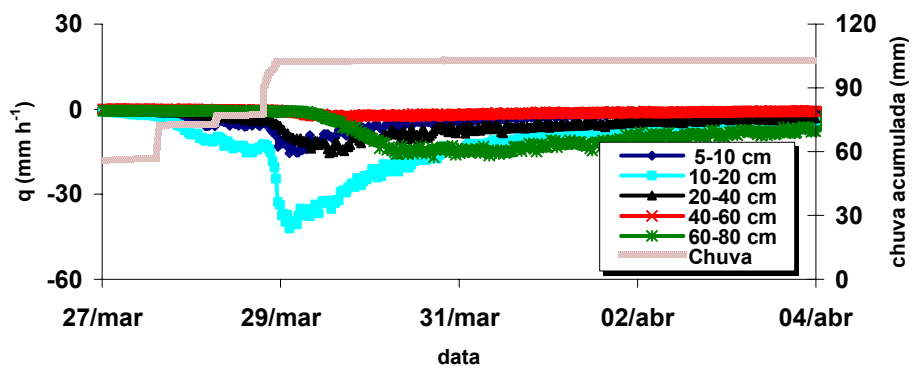

Plantio

direto

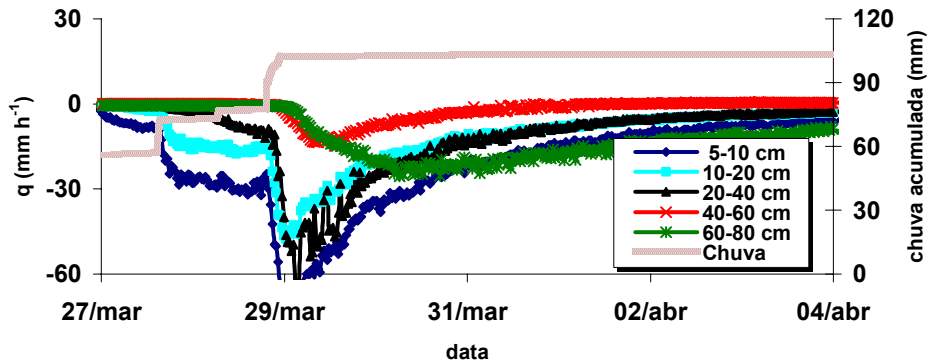

Preparo

convencional

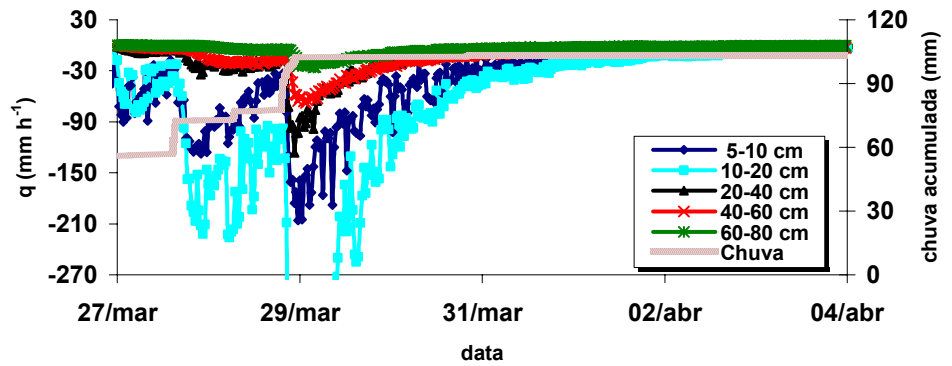

Solo nu

Figura 22 -Densidade de fluxo de água no solo ( $\mathrm{q}, \mathrm{mm} \mathrm{h}^{-1}$,valores de $30 \mathrm{em} 30 \mathrm{~min}$ ) nos tratamentos grama, plantio direto, preparo convencional e solo nu, para as camadas de 5 a $10 \mathrm{~cm}, 10$ a $20 \mathrm{~cm}, 20$ a $40 \mathrm{~cm}, 40$ a $60 \mathrm{~cm}$ e de 60 a $80 \mathrm{~cm}$ e chuva acumulada no período de 27 de março a 4 de abril de 2000. 
No segundo ano de cultivo (safra 2000 a 2001), após o restabelecimento dos tratamentos, reimplantados em novembro de 2000 com a semeadura de milho nos tratamentos plantio direto e preparo convencional, além da manutenção da cobertura vegetal do tratamento grama e a retirada de qualquer vegetação presente sobre o solo do tratamento solo nu, reiniciaram-se as leituras com o TDR para a determinação da umidade do solo ao longo do tempo para a determinação das densidades de fluxo de água no perfil do canal do terraço de cada tratamento. Desta vez, as leituras foram feitas manualmente, na indisponibilidade dos multiplexers. As deposições de solo erodido e depositado sobre o canal do terraço de cada tratamento, ao longo do $1^{\circ}$ ano de cultivo, foram mantidas no local.

Observa-se que o comportamento das densidades de fluxo permaneceu semelhante ao apresentado durante $\circ 1^{\circ}$ ano (Figuras 23 e 24), no entanto, as diferenças entre os tratamentos plantio direto e preparo convencional tornaram-se ainda maiores. Neste período, o plantio direto apresentava-se com maior cobertura vegetal devido à presença de restos culturais do milho do $1^{\circ}$ ano sobre o solo e pela presença do milho implantado nesse segundo ano de cultivo. O preparo convencional contava somente com o milho implantado sobre o tratamento, já que os restos culturais de milho do primeiro cultivo haviam sido incorporados pelas operações de preparo do solo efetuadas para a semeadura de milho nesse segundo ano de cultivo. As menores densidades de fluxo de água observadas no tratamento plantio direto, em relação às densidades de fluxo do preparo convencional, podem também ter sido devido à formação de um grande sulco no tratamento convencional após o preparo do solo nesse $2^{\circ}$ ano de cultivo (Figura 23). A formação desse sulco pode ter sido causada pelo fato de o solo apresentar-se susceptível à ação das chuvas, tanto pela pulverização pelas operações de preparo, como mencionado na discussão relacionada ao $1^{\circ}$ ano de cultivo, quanto pela incorporação e redução dos restos culturais sobre a superfície do solo, o que facilitou a ação da enxurrada e aumentou a probabilidade de formação de novos sulcos. Em janeiro de 2001 (Figura 24), pôde-se observar, ainda melhor, que a presença de pequenas chuvas sobre o solo nu alterou em muito as densidades de fluxo, principalmente, nas camadas mais superficiais. Essa variação se deveu a presença de uma maior enxurrada devido ao aumento do selamento superficial do solo com conseqüente redução da taxa instantânea de infiltração. Nos 
demais tratamentos as densidades de fluxo, praticamente, não foram alteradas, inclusive nas camadas mais superficiais.

Verifica-se, portanto, que apesar das grandes diferenças de deposição de solo sobre o canal de cada terraço, as densidades de fluxo são mais influenciadas pela deposição de água sobre o canal, do que pela deposição de solo. A maior deposição de água sobre o canal ocorreu nos tratamentos de menor presença de cobertura vegetal, provavelmente, devido à formação de selamento superficial que reduziu a infiltração de água na área a montante do terraço.

Devido às diversas incertezas no cálculo das densidades de fluxo aqui apresentadas, principalmente no que diz respeito à condutividade hidráulica, este parâmetro não pôde ser tomado como base para fazer inferências quanto a diferenciação entre tratamentos ou para estimar a taxa de infiltração de água no canal do terraço. 


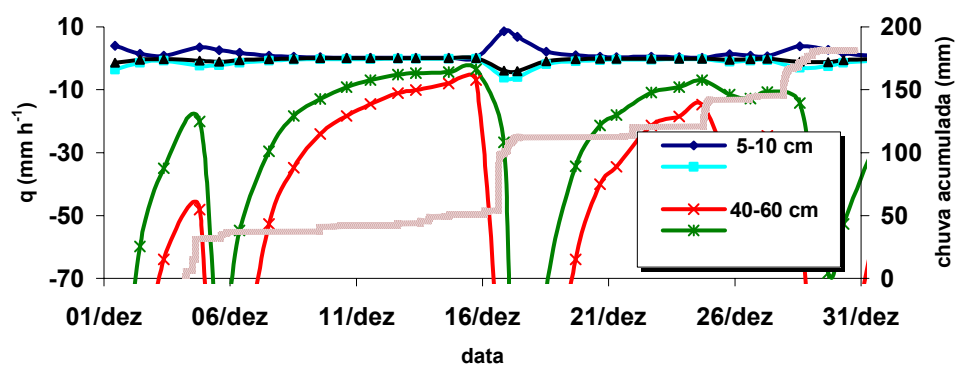

Grama

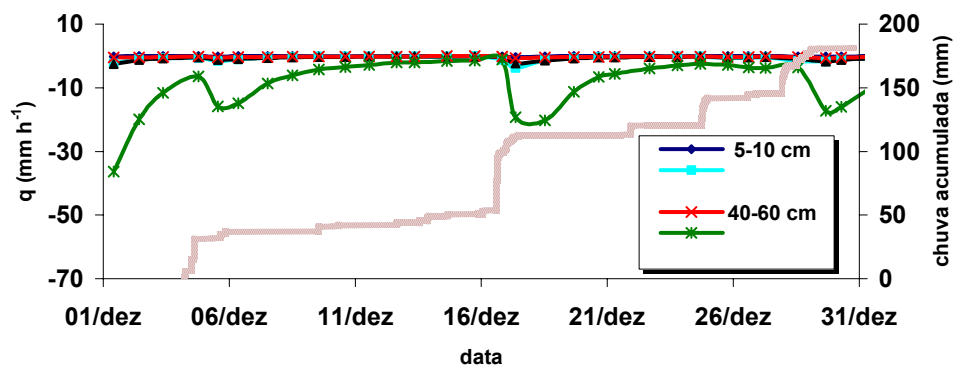

Plantio

direto

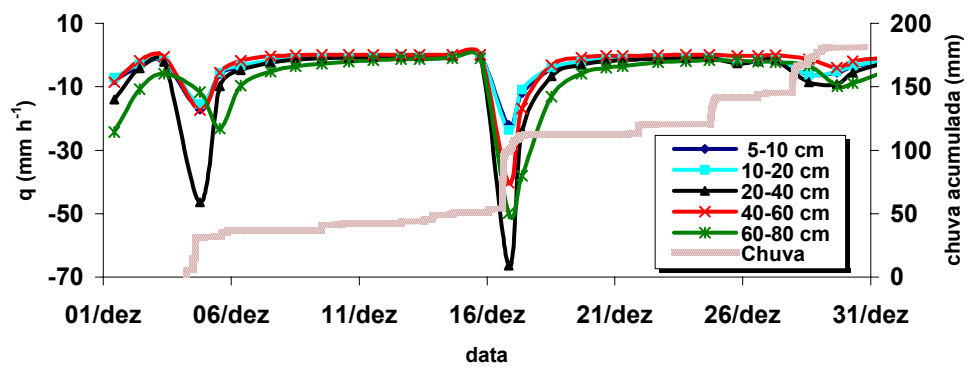

Preparo

convencional

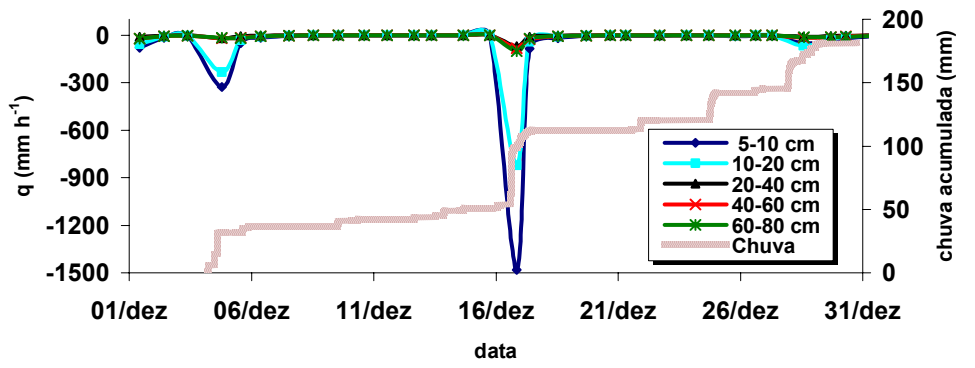

Solo nu

Figura 23 - Média diária da densidade de fluxo de água no solo (q, $\mathrm{mm} \mathrm{h}^{-1}$ ) nos tratamentos grama, plantio direto, preparo convencional e solo nu, para as camadas de 5 a $10 \mathrm{~cm}, 10$ a $20 \mathrm{~cm}, 20$ a $40 \mathrm{~cm}, 40$ a $60 \mathrm{~cm}$ e de 60 a $80 \mathrm{~cm}$ e chuva acumulada no mês de dezembro de 2000 . 


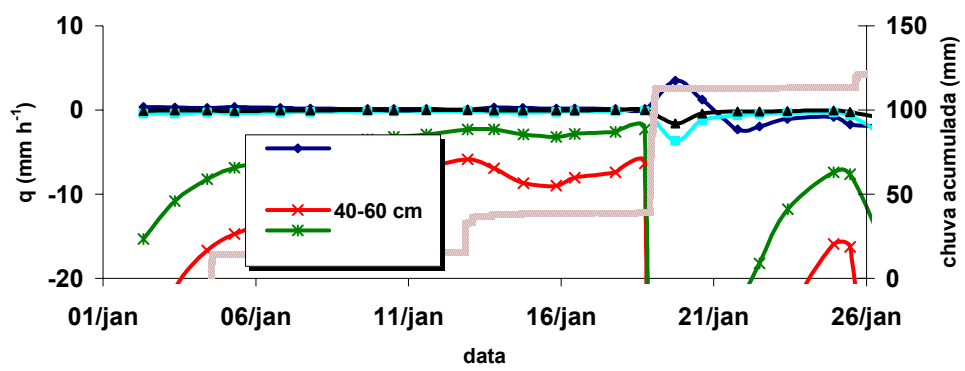

Grama

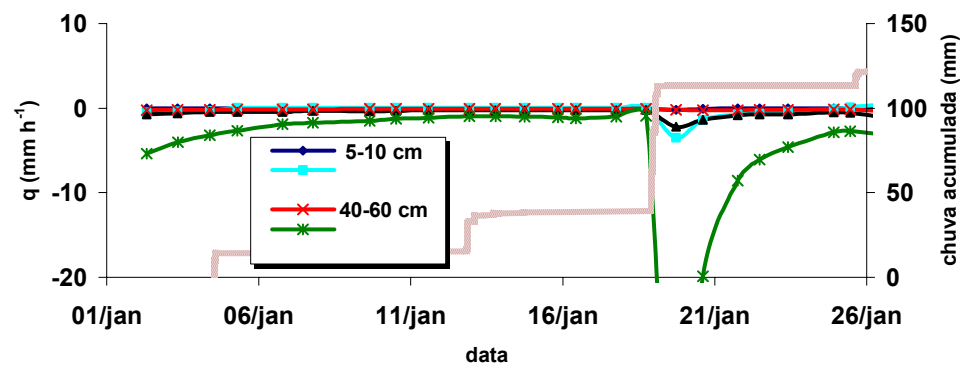

Plantio

direto

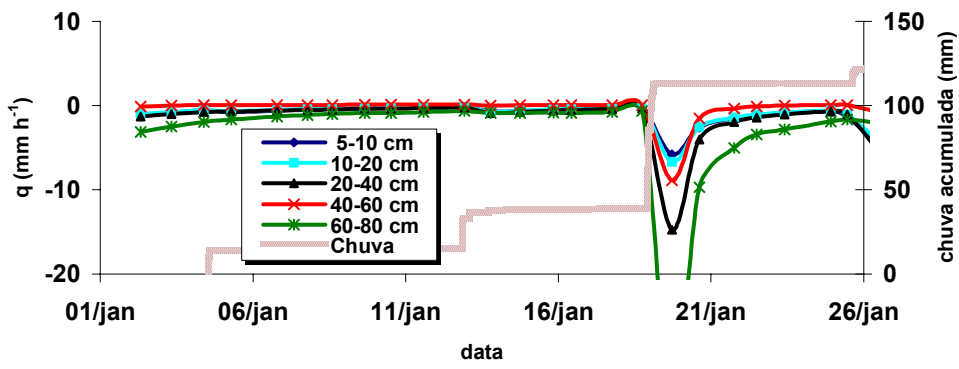

Preparo

convencional

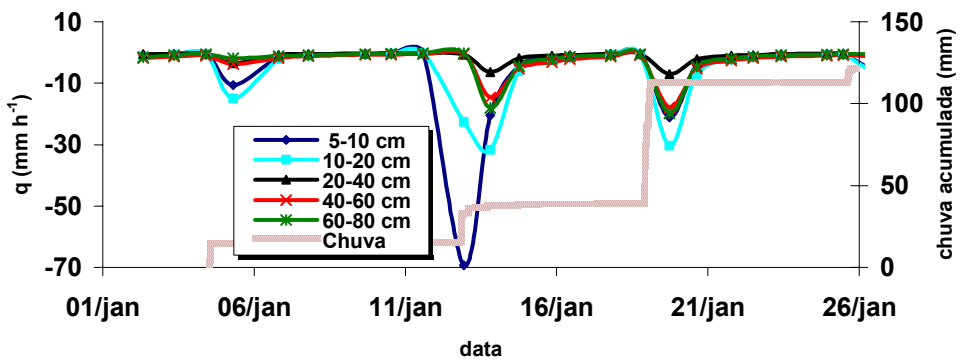

Solo nu

Figura 24 - Média diária da densidades de fluxo de água no solo (q, $\mathrm{mm} \mathrm{h}^{-1}$ ) nos tratamentos grama, plantio direto, preparo convencional e solo nu, para as camadas de 5 a $10 \mathrm{~cm}, 10$ a $20 \mathrm{~cm}, 20$ a $40 \mathrm{~cm}, 40$ a $60 \mathrm{~cm}$ e de 60 a $80 \mathrm{~cm}$ e chuva acumulada no mês de janeiro de 2001. 


\subsection{Armazenagem de água no solo do canal do terraço}

\subsubsection{Março de $2000-1^{\circ}$ ano de cultivo}

Março de 2000 foi caracterizado por chuvas de maior volume somente na segunda metade do mês (item 4.4). Verifica-se que a pequena chuva do dia 07/03 deixou de influenciar na armazenagem nos tratamentos plantio direto e preparo convencional, enquanto os tratamentos grama e solo nu tiveram suas armazenagens bastante afetadas (Figuras 25 e 26). Nesse mês, o acúmulo de material sobre o terraço ainda era pequeno e assim não se detectam grandes diferenças entre as armazenagens representadas pela Figura 25 (desconsiderando a camada de deposição) e Figura 26 (considerando essa camada).

Os tratamentos preparo convencional e solo nu sofreram maiores variações no armazenamento devido à presença de uma maior deposição de água sobre o canal proveniente das maiores enxurradas que por sua vez reduziram a capacidade de infiltração de água no solo a montante do terraço. A variabilidade da deposição de água sobre o canal pode ser observada, com clareza, no tratamento solo nu, principalmente através do acúmulo sobre um dos pontos de observação (repetição 1 , indicada pela seta na Figura 27). Esta variabilidade ocorreu devido à deposição irregular de solo sobre o canal proveniente do transporte de solo e água pela enxurrada. Apesar dessa diferença entre as repetições, a quantidade de água depositada sobre $\mathrm{o}$ canal desse tratamento proporcionou acúmulo de aproximadamente $50 \mathrm{~mm}$ de água no perfil do terraço enquanto que os demais tratamentos apresentaram variações ao redor de $30 \mathrm{~mm}$. As diferenças entre as repetições foram nítidas, principalmente entre as repetições do tratamento preparo convencional. No caso dos tratamentos grama e plantio direto, as variações entre as repetições não se devem, principalmente às irregularidades nas deposições de material erodido já que estas foram bastante pequenas durante todo o período de condução do experimento. Em relação à maior armazenagem observa-se na repetição 2 do tratamento grama, notadamente no início do mês, comenta-se que esta pode ser devido ao fato de a estimativa das armazenagens parciais das camadas de 0,15 a $0,30 \mathrm{~m}$ e de 0,50 a $0,90 \mathrm{~m}$ nesse tratamento serem calculadas com base na umidade dos sensores localizados mais superficialmente $(0,10 \mathrm{~m}$ e $0,40 \mathrm{~m}$, 
respectivamente), que provavelmente se encontravam em regiões mais úmidas do perfil.

As armazenagens de água corrigidas para a nova cota superficial do canal devido à deposição de solo proveniente da enxurrada ao longo do tempo não sofreram grandes alterações em relação às armazenagens de água obtidas desconsiderando-se a deposição de solo, exceto ao final do período onde ocorreram as maiores chuvas e maiores deposições de água. Estas permitiram um pequeno aumento da armazenagem de água pelo canal (Figura 26), principalmente nos tratamentos de menor cobertura vegetal (preparo convencional e solo nu) já que as deposições de água sobre estes canais foram ainda maiores do que as deposições ocorridas nos terraços dos demais tratamentos, tanto pela menor capacidade de infiltração de água quanto pela maior capacidade de retenção de água pelo solo depositado sobre a superfície original do canal do terraço. É importante lembrar que essas armazenagens foram estimadas considerando-se que a umidade nos depósitos fosse igual a umidade da camada de 0-0,10 m.

Fato importante de se observar é que a variação da armazenagem foi, em todos os tratamentos, inferior à lâmina de chuva, que acumulou cerca de $90 \mathrm{~mm}$, no mesmo período. Se não houvesse evaporação, fluxo lateral e/ou drenagem profunda e desconsiderando-se a presença de enxurradas sobre os tratamentos, o acúmulo de água no canal de cada tratamento deveria ser, no mínimo, igual a $90 \mathrm{~mm}$. Isso indica, que ao contrário do assumido ocorreram perdas de água e que estas foram de, no mínimo, cerca de $60 \mathrm{~mm}$ (90 mm proveniente das chuvas menos $30 \mathrm{~mm}$ da armazenagem detectada nos terraços).

Como possíveis meios de perdas de água tem-se a evaporação, a drenagem profunda ou ascensão capilar do solo do canal do terraço em direção ao camalhão (fluxo lateral). Quanto à evaporação, considerando que se trata de um período chuvoso ou pelo menos nublado, esta não deve ter sido superior a $3 \mathrm{~mm} \mathrm{dia}^{-1}$ e poderia, assim, acumular uma perda de $30 \mathrm{~mm}$ para o período de 10 dias. A ascensão capilar para o interior do camalhão do terraço (fluxo lateral) pode ter sido um processo responsável pela perda de uma quantidade considerável de água. Esse processo é pouco discutido e pode ser que contribua bastante para a capacidade de armazenagem do sistema camalhão-canal. A absorção de água pelo camalhão aceleraria a redução da umidade 
do solo do canal do terraço, aumentando a capacidade de infiltração instantânea e sua eficiência na absorção da água de enxurradas. A drenagem profunda é o fator que mais provavelmente tenha contribuído com a maior perda de água. Na Figura 20 (item 4.6) verifica-se que a densidade de fluxo de água, da camada mais profunda $(0,60$ a $0,80 \mathrm{~m})$, logo após as chuvas, atingiu valores da ordem de $10 \mathrm{~mm} \mathrm{~h}^{-1}$ (240 mm dia ${ }^{-1}$ ) ou maior. Apesar dos problemas na determinação dos valores das densidades de fluxo, tomando-se como base a ordem de grandeza citada anteriormente, é marcante a importância da drenagem profunda na variação da armazenagem de água no canal do terraço. Dessa forma a variação da armazenagem estimada nesse item pode apenas ser relacionada com a intensidade das enxurradas de forma qualitativa. 


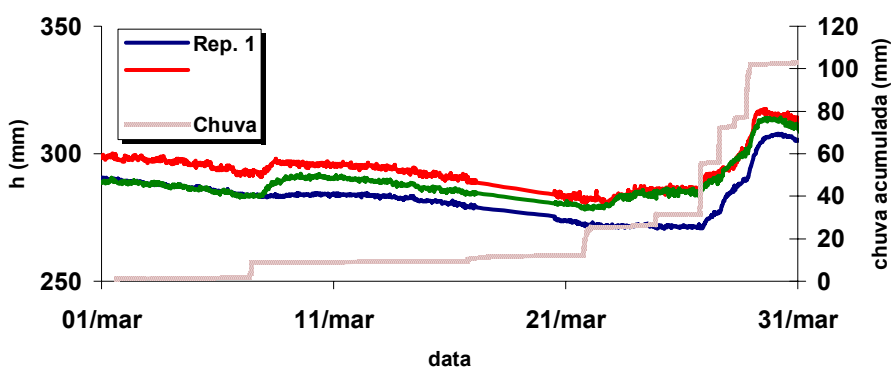

Grama

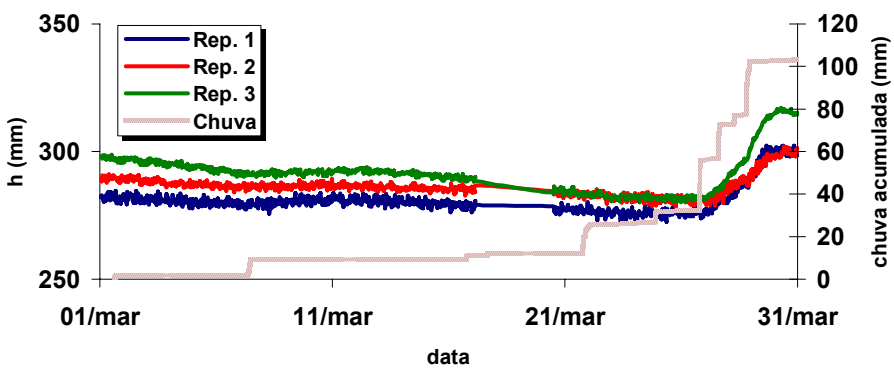

Plantio

direto

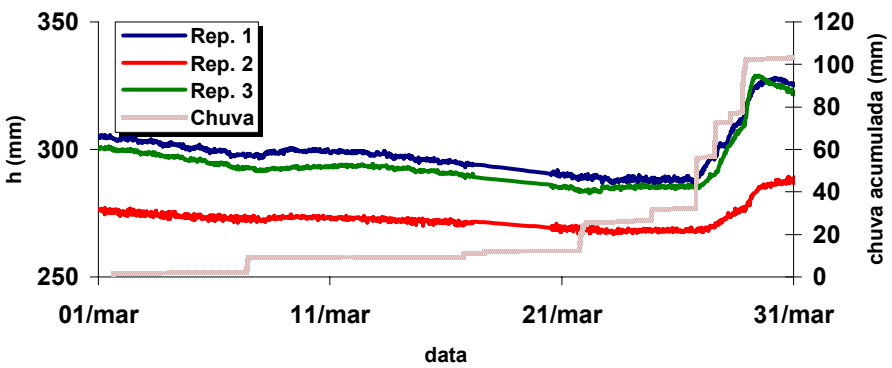

Preparo

convencional

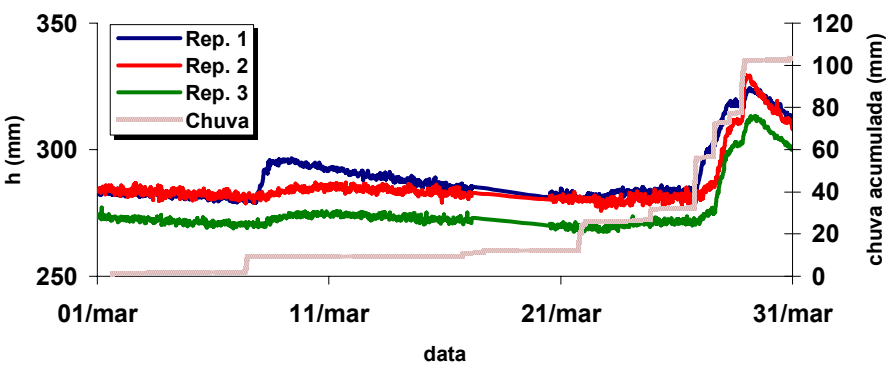

Solo nu

Figura 25 - Armazenagem de água no perfil de solo entre a superfície original e a profundidade $0,9 \mathrm{~m}(\mathrm{~h}, \mathrm{~mm})$, nos tratamentos grama, plantio direto, preparo convencional e solo nu e a chuva acumulada no mês de março de 2000. 


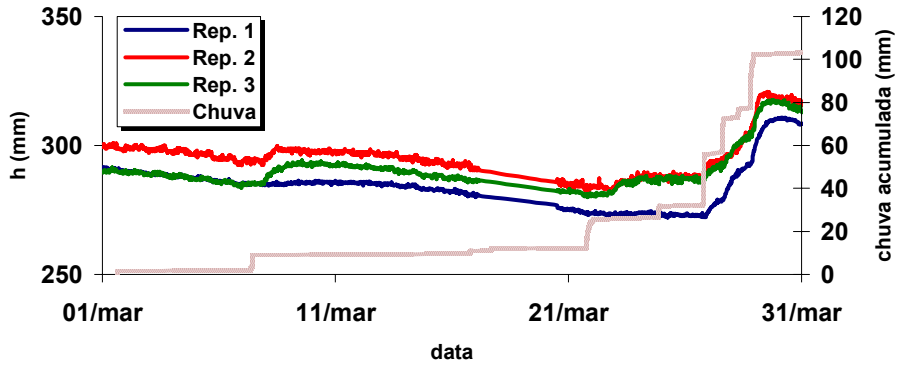

Grama

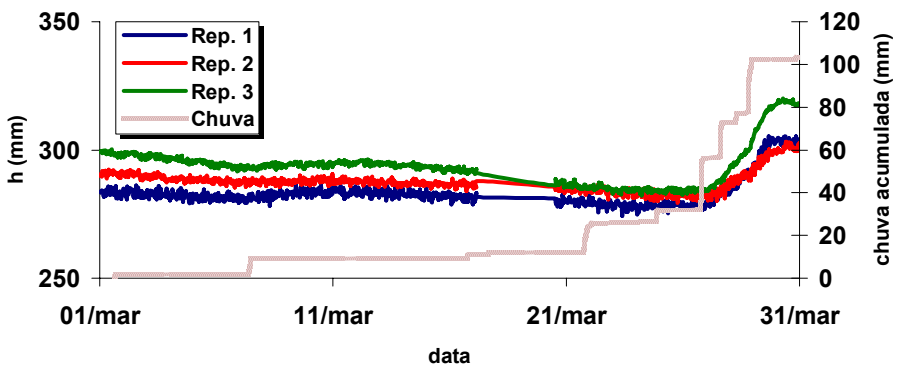

Plantio direto

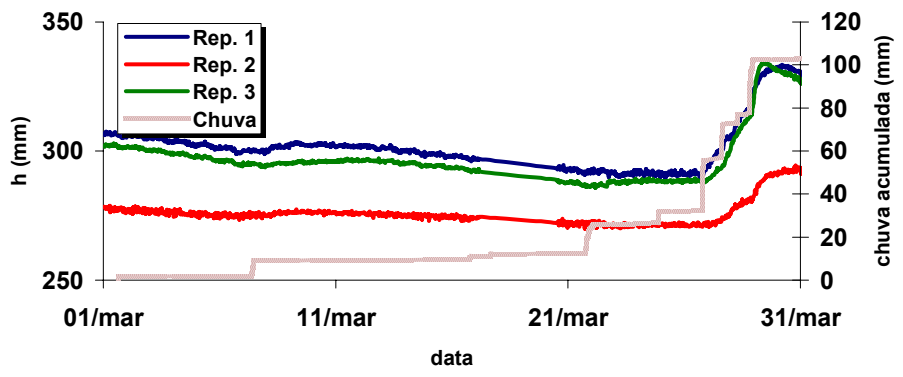

Preparo convencional

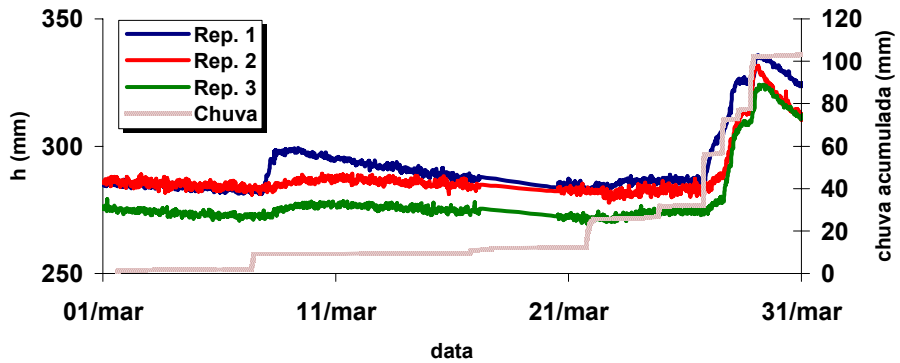

Solo nu

Figura 26 - Armazenagem de água no perfil de solo considerando a camada de deposição sobre a superfície do canal (h, $\mathrm{mm}$ ), nos tratamentos grama, plantio direto, preparo convencional e solo nu e a chuva acumulada no mês de março de 2000. 


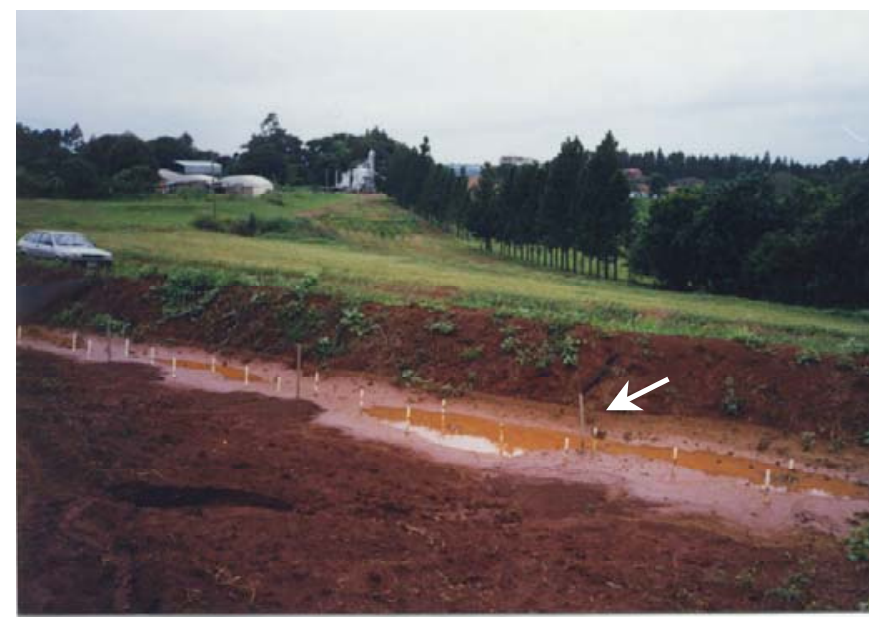

Figura 27 - Distribuição da água sobre o canal do terraço do tratamento solo nu, após o término de uma chuva, e a incidência de um maior acúmulo sobre uma das repetições.

\subsubsection{Dezembro de $2000-2^{\circ}$ ano de cultivo}

Os gráficos de armazenagem versus tempo referentes ao mês de dezembro/2000 (Figuras 28 e 29) apresentam um menor detalhamento que os de março (Figuras 25 e 26) devido ao fato de que as leituras dos sensores foram feitas somente uma vez ao dia quando na presença de chuvas de baixa intensidade ou ausência das mesmas. No caso de presença de chuvas mais intensas, as leituras foram feitas de 30 em 30 minutos até logo após seu término.

O comportamento da armazenagem durante este mês foi semelhante ao ocorrido no mês de março, no entanto, as variações das armazenagens foram mais intensas, possivelmente devido a maiores enxurradas e acúmulo de material erodido sobre os canais dos terraços. As maiores variações de armazenagem ocorreram, novamente, nos tratamentos solo nu e preparo convencional. A presença de menor cobertura vegetal, associada ou não a redução da estabilidade de agregados do solo pela movimentação do mesmo no momento do preparo (Allmaras et al., 1967), caso do preparo convencional, provavelmente propiciou a formação de selamento superficial e, com isso, a redução da capacidade de infiltração de água pela área a montante do terraço, levando a maiores volumes de enxurrada e, por conseguinte, a um maior 
acúmulo de água sobre o canal, gerando uma maior armazenagem de água no perfil desse tratamento (Figura 28).

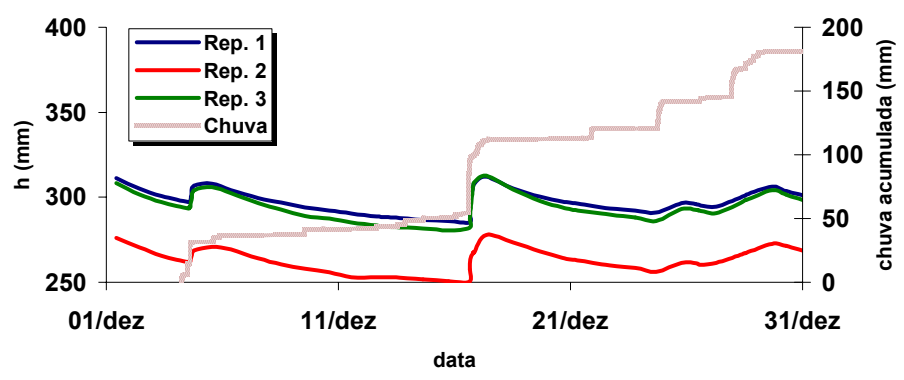

Grama

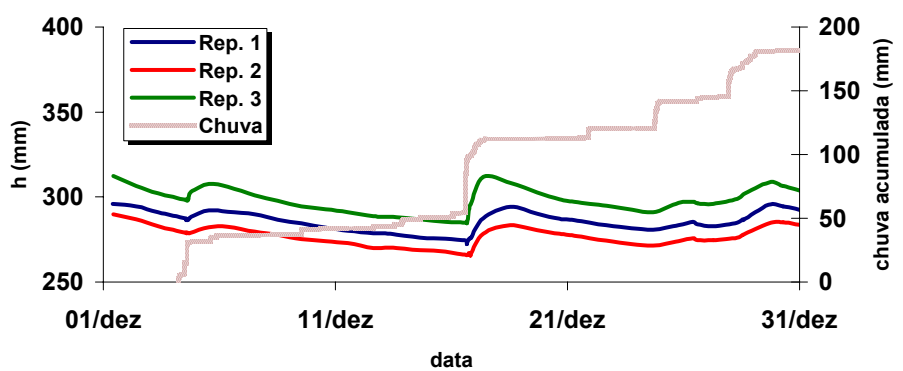

Plantio

direto

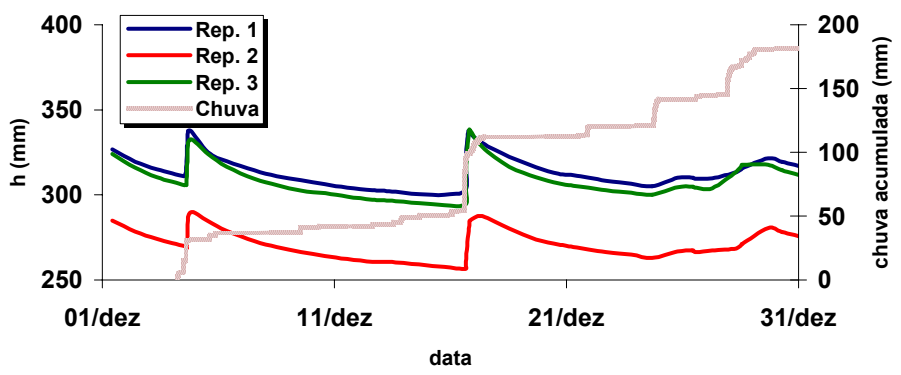

Preparo

convencional

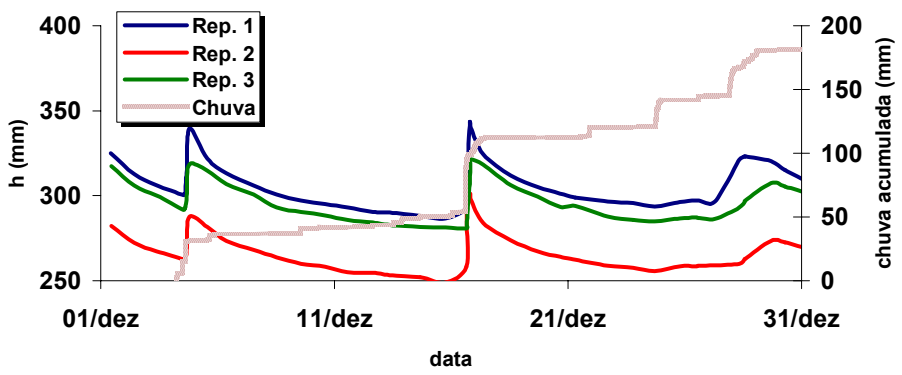

Solo nu

Figura 28 - Armazenagem de água no perfil de solo entre a superfície original e a profundidade $0,9 \mathrm{~m}(\mathrm{~h}, \mathrm{~mm})$, nos tratamentos grama, plantio direto, preparo convencional e solo nu e a chuva acumulada no mês de dezembro de 2000. 
A variação entre as repetições de armazenagem dentro de cada tratamento foi ainda maior, provavelmente, pela variabilidade do solo e da superfície do próprio canal, pela a deposição seletiva do material erodido, associada à ocorrência de maior ou menor intensidade dos processos de evaporação, drenagem profunda e fluxos laterais em cada um dos pontos de observação (repetição).

No caso da repetição 2 do tratamento preparo convencional, a armazenagem de água comportou-se de maneira diferenciada das demais, apresentando valores ainda menores devido ao aparecimento de um grande sulco em direção da região central do canal. O sulco proporcionou uma grande deposição de material erodido, sobre o local onde se encontrava a referida repetição, aumentando assim a cota deste local e, com isso, reduzindo a deposição e a armazenagem de água sobre esta região do canal. Esse tipo de observação demonstra as dificuldades de se obter valores representativos da umidade e dos fluxos de água nas condições de um canal de terraço de infiltração.

As repetições do tratamento solo nu apresentaram-se também mais discrepantes devido, principalmente, à variabilidade da deposição de solo e água sobre o canal. As deposições de solo ocorrem de forma seletiva, depositando partículas de maior ou menor tamanho, de acordo com a presença de chuvas mais ou menos erosivas, as quais despedem uma maior ou menor energia de cisalhamento, respectivamente (Ellison, 1947; Smith \& Wischmeier, 1962). As deposições de água ocorrem, preferencialmente, sobre as superfícies de menores cotas, como é o caso dos locais de menor deposição de solo sobre o canal. As deposições diferenciadas de água e solo sobre o canal auxiliaram na variabilidade da superfície e, com isso, na armazenagem de água do solo, provocando respostas variadas entre as repetições.

As armazenagens de água, considerando-se a camada de material erodido sobre a superfície do canal dos tratamentos grama e plantio direto, praticamente não sofreram alterações em relação às armazenagens estimadas utilizando-se como base o nível original do solo devido à pequena perda de água e solo ocorrida nesses tratamentos. No entanto, as armazenagens estimadas para os tratamentos preparo convencional e, principalmente, o solo nu apresentaram um grande acréscimo em seus valores devido as maiores perdas de água e solo por eles apresentada (Figura 29). 


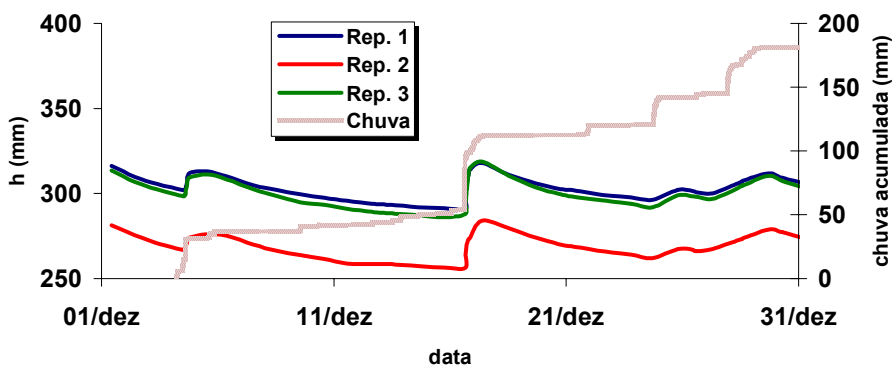

Grama

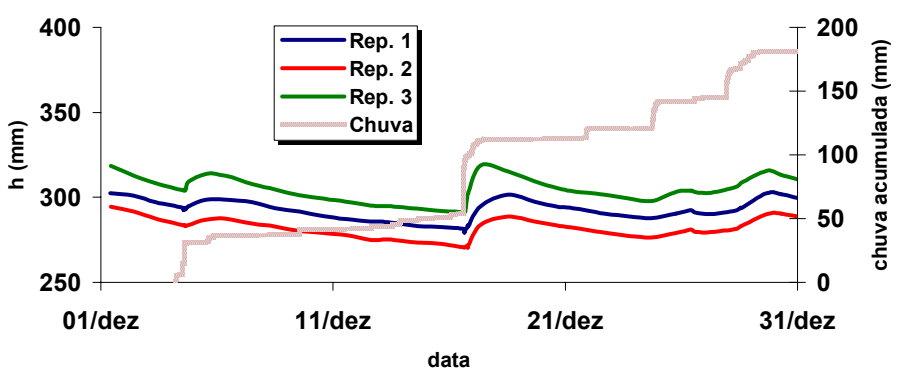

Plantio

direto

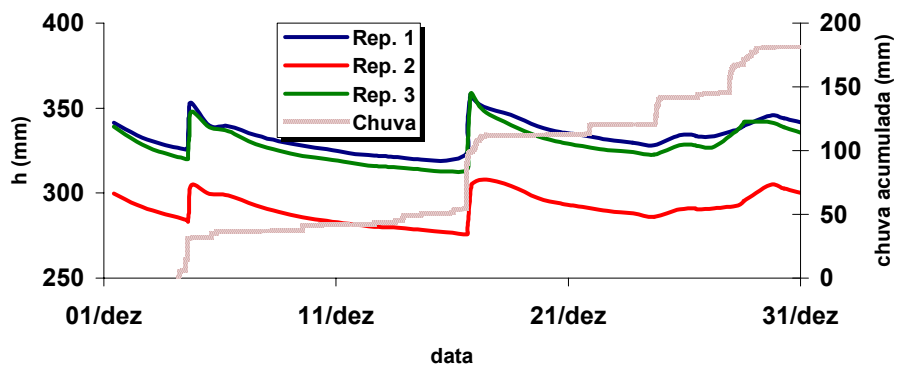

Preparo

convencional

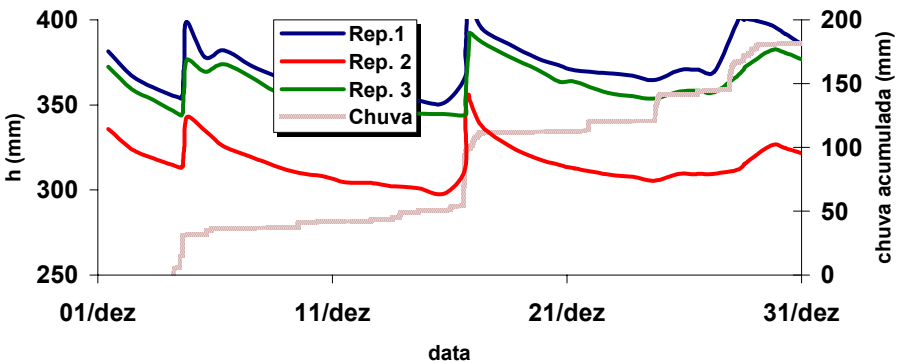

Solo nu

Figura 29 - Armazenagem de água no perfil de solo considerando a camada de deposição sobre a superfície do canal ( $h, \mathrm{~mm})$, nos tratamentos grama, plantio direto, preparo convencional e solo nu e a chuva acumulada no mês de dezembro de 2000. 


\subsection{Taxa de infiltração de água no canal e na área a montante após chuvas}

\subsubsection{Taxa de infiltração desconsiderando fluxo na profundidade de $\mathbf{0 , 9 0} \mathrm{m}$}

Devido às dificuldades da estimativa da relação $\mathrm{K}-\theta$, discutidas anteriormente, verificou-se a possibilidade de estimar as taxas de infiltração de água com base apenas nas variações de armazenagem de água no canal do terraço. Por esse procedimento evita-se a utilização dos valores de K- $\theta$. Por outro lado, ao considerar que a avaliação da armazenagem equivale à lâmina de água infiltrada, desprezam-se perdas ou ganhos por drenagem/ascensão (fluxos laterais) e por evaporação. Supondo que essas perdas/ganhos são relativamente pequenas, quando comparadas às intensidades das chuvas, essa aproximação poderia ser boa.

A taxa de infiltração de água no solo do canal e da área a montante do terraço foi estimada, considerando não haver fluxo abaixo da profundidade 0,90 m, para três chuvas no mês de março e dezembro (Figuras 30 e 31). Estas chuvas foram escolhidas pode ter causado maiores variações nas armazenagens de água no canal do terraço (item 4.7). O volume, duração e intensidade das chuvas, bem como o tempo de armazenagem no canal e na área a montante do terraço encontram-se na Tabela 15. Na Figura 30 estão representadas as três chuvas ocorridas no mês de março que afetaram o fluxo de água no canal do terraço em pelo menos um dos tratamentos. A chuva que ocorreu no dia 07/03/00, de baixo volume, teve praticamente todo o seu volume de água infiltrado na área a montante do terraço sendo que uma pequena quantidade de água chegou ao canal, como é demonstrado na Tabela 16, para todos os tratamentos. Essa tabela mostra também que no canal do tratamento solo nu houve sempre a maior absorção de água das chuvas. Deve ser lembrado, ainda, que a área considerada para o canal do tratamento solo nu foi maior que a dos demais tratamentos. 

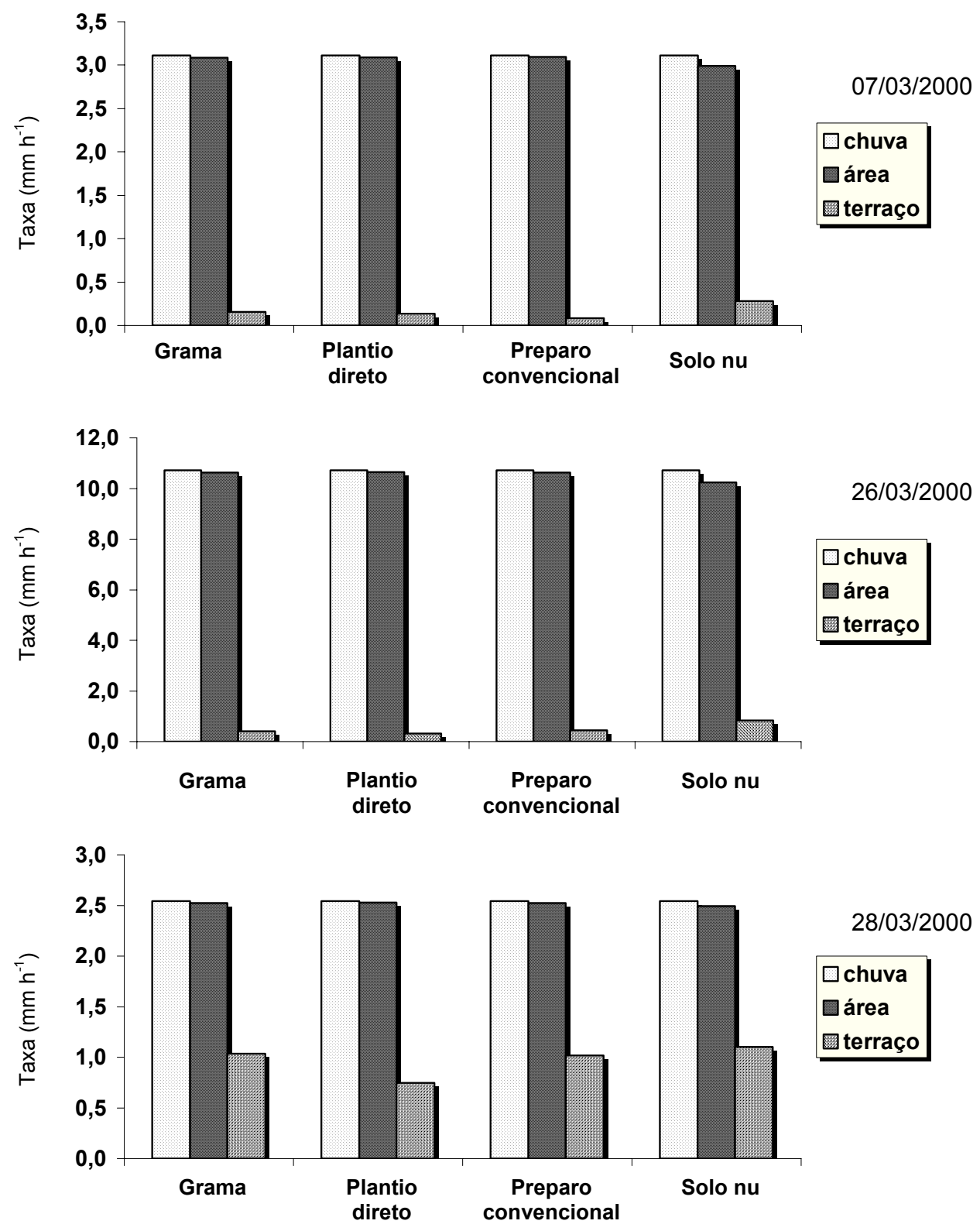

Figura 30 - Taxa de chuva e de infiltração da água no terraço e na área a montante do terraço nos dias $07 / 03 / 00,26 / 03 / 00$ e $28 / 03 / 00$ para os tratamentos grama, plantio direto, preparo convencional e solo nu, considerando a armazenagem até a profundidade $0,90 \mathrm{~m}$ e a ausência de fluxo abaixo desta.

A chuva mais marcante que ocorreu no período foi a do dia $26 / 03 / 00$, de maior volume e intensidade mas com duração aproximada à anteriormente citada. Apesar da 
maior intensidade, as taxas de infiltração observadas foram semelhantes às da chuva do dia 07/03/00 provavelmente devido à baixa umidade que o solo encontrava-se antes da chuva, aumentando a capacidade de infiltração na área a montante do terraço e, com isso, uma baixa taxa de infiltração no canal. Verifica-se ainda que a fração dessa chuva absorvida pelo canal do terraço foi maior nos tratamentos preparo convencional e solo nu.

No dia 28/03/00 ocorreu uma chuva com o mesmo volume do dia 26/03/00 porém de maior duração, levando a uma menor intensidade. No entanto, as taxas de infiltração de água estimadas no canal do terraço foram ainda maiores, sugerindo que houve efeito da umidade antecedente do solo sobre as taxas de infiltração uma vez que a taxa de infiltração de água da área a montante do terraço foi reduzida, proporcionando uma maior enxurrada e, com isso, maiores acúmulos de água e solo nos canais dos terraços.

Tabela 15. Características das chuvas e duração das armazenagens de água no canal e na área a montante do canal.

\begin{tabular}{|c|c|c|c|c|c|}
\hline \multirow[t]{2}{*}{ DATA } & \multicolumn{2}{|c|}{ Chuva } & \multirow{2}{*}{$\begin{array}{c}\text { Intensidade } \\
\text { da chuva } \\
\left(\mathrm{mm} \mathrm{h}^{-1}\right)\end{array}$} & \multicolumn{2}{|c|}{$\begin{array}{l}\text { Tempo da armazenagem de águe } \\
\qquad(\mathrm{h})\end{array}$} \\
\hline & $\begin{array}{l}\text { Volume } \\
(\mathrm{mm})\end{array}$ & $\begin{array}{c}\text { Duração } \\
\text { (h) }\end{array}$ & & $\begin{array}{c}\text { Área total da } \\
\text { parcela }\end{array}$ & Terraço \\
\hline $07 / 03 / 2000$ & 7,62 & 2,45 & 3,11 & 2,45 & 34,20 \\
\hline $26 / 03 / 2000$ & 24,13 & 2,25 & 10,72 & 2,25 & 43,00 \\
\hline $28 / 03 / 2000$ & 25,40 & 10,00 & 2,54 & 10,00 & 14,00 \\
\hline $04 / 12 / 2000$ & 31,50 & 17,33 & 1,82 & 17,33 & 4,50 \\
\hline $16 / 12 / 2000$ & 58,67 & 20,88 & 2,81 & 20,88 & 4,00 \\
\hline $27 / 12 / 2000$ & 35,81 & 35,15 & 1,02 & 35,15 & 57,00 \\
\hline
\end{tabular}


Tabela 16. Fração de água da chuva infiltrada no canal do terraço $\left(f_{t}, m^{3} m^{-3}\right)$ e na área a montante $\left(f_{a}, \mathrm{~m}^{3} \mathrm{~m}^{-3}\right)$, desconsiderando a presença de fluxo abaixo de $0,90 \mathrm{~m}$ para todos os tratamentos.

\begin{tabular}{ccccccccc}
\hline \multirow{2}{*}{ Data } & \multicolumn{2}{c}{ Grama } & \multicolumn{2}{c}{ Plantio direto } & \multicolumn{2}{c}{ Preparo convencional } & \multicolumn{2}{c}{ Solo nu } \\
\cline { 2 - 9 } & $\mathrm{f}_{\mathrm{a}}$ & $\mathrm{f}_{\mathrm{t}}$ & $\mathrm{f}_{\mathrm{a}}$ & $\mathrm{f}_{\mathrm{t}}$ & $\mathrm{f}_{\mathrm{a}}$ & $\mathrm{f}_{\mathrm{t}}$ & $\mathrm{f}_{\mathrm{a}}$ & $\mathrm{f}_{\mathrm{t}}$ \\
\hline $07 / 03 / 2000$ & 0,992 & 0,008 & 0,993 & 0,007 & 0,996 & 0,004 & 0,963 & 0,037 \\
$26 / 03 / 2000$ & 0,991 & 0,009 & 0,993 & 0,007 & 0,990 & 0,010 & 0,955 & 0,045 \\
$28 / 03 / 2000$ & 0,993 & 0,007 & 0,995 & 0,005 & 0,993 & 0,007 & 0,982 & 0,018 \\
& & & & & & & & \\
$04 / 12 / 2000$ & 0,997 & 0,003 & 0,999 & 0,001 & 0,990 & 0,010 & 0,962 & 0,038 \\
$16 / 12 / 2000$ & 0,995 & 0,005 & 0,999 & 0,001 & 0,993 & 0,007 & 0,971 & 0,029 \\
$27 / 12 / 2000$ & 0,996 & 0,004 & 0,996 & 0,004 & 0,995 & 0,005 & 0,976 & 0,024 \\
\hline
\end{tabular}

Em dezembro, as taxas de infiltração de água estimadas nos terraços foram ainda maiores, provavelmente pelo maior volume de água acumulado no canal após a ação das chuvas e pela maior quantidade de água armazenada devido à deposição de uma camada de solo proveniente da erosão sobre a superfície do canal. Apesar de todas as chuvas precipitadas durante esse mês serem de baixa duração, o solo encontrava-se bastante úmido, suficiente para alterar a armazenagem de água no solo e permitir a avaliação das taxas de infiltração. Esta maior umidade do solo proporcionou um aumentou do volume de enxurrada, aumentando, também o volume de água acumulado sobre o canal. Conseqüentemente, a água acumulada sobre o canal aumentou a taxa de infiltração de água, principalmente nos tratamentos de menor cobertura vegetal como o solo nu e o preparo convencional (Figura 31). Por outro lado, pela Tabela 16 verifica-se que a fração da água infiltrada no terraço não variou significativamente entre março e dezembro. 

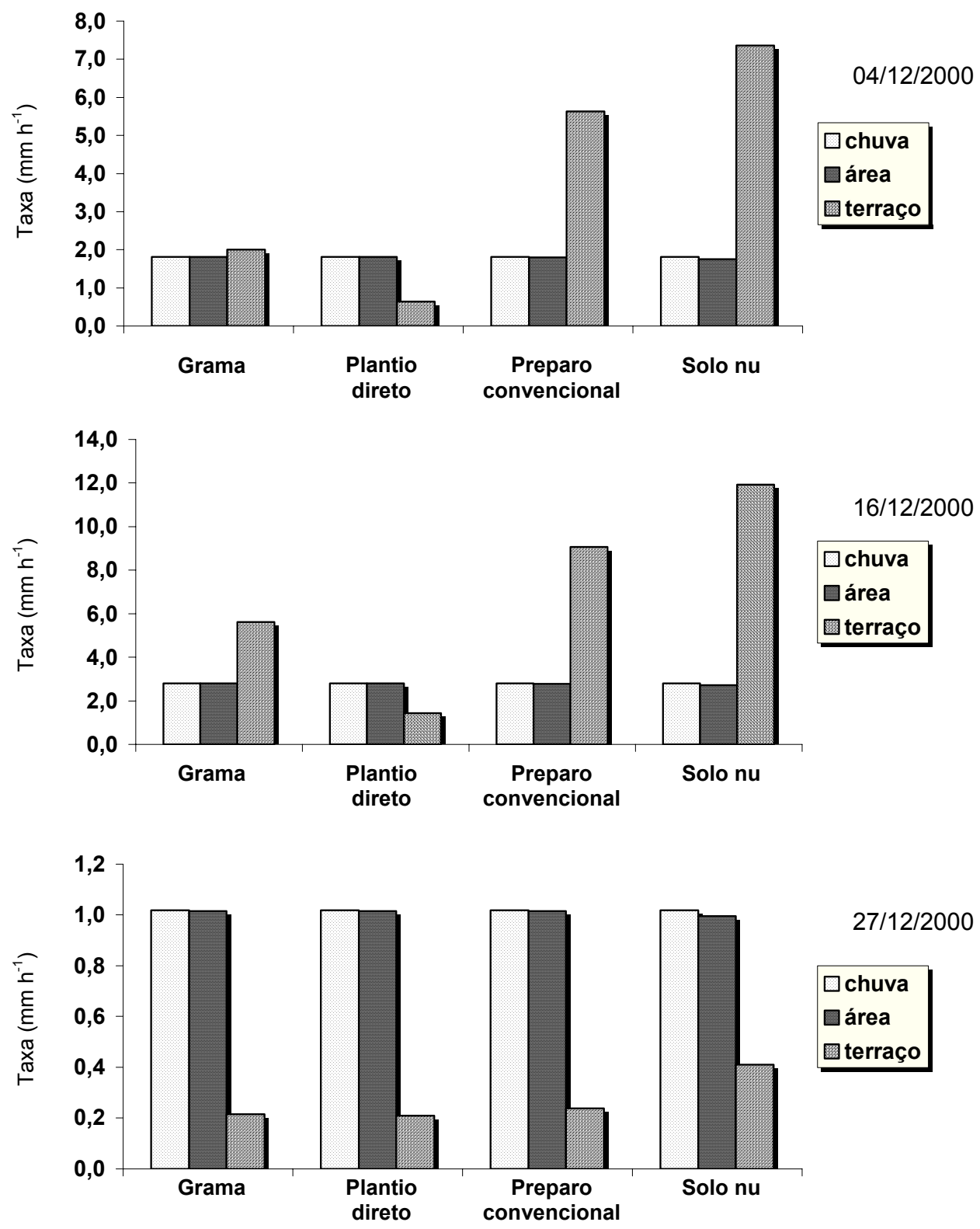

Figura 31 - Taxa de chuva e de infiltração da água no terraço e na área a montante do terraço nos dias 04/12/00, 16/12/00 e 27/12/00 para os tratamentos grama, plantio direto, preparo convencional e solo nu, considerando a armazenagem até a profundidade $0,90 \mathrm{~m}$ e a ausência de fluxo abaixo desta. 
A chuva do dia 16/12/00, de maior volume $(58,67 \mathrm{~mm})$ e duração, proporcionou taxas de comportamento semelhantes ocorridas após a chuva do dia 04/12/00 porém, em maiores proporções. Nesse caso, o maior acúmulo de água no terraço pode ser demonstrado pelo maior estimativa das taxa de infiltração no canal de todos tratamentos, exceto no plantio direto. Acredita-se que a elevada taxa de infiltração estimada no canal do tratamento grama, notadamente observada pelos dias 4 e 16/12/00 possa ser devido a problemas nas medidas com TDR (item 4.2) em pelo menor uma das repetições.

Novamente uma chuva de baixa intensidade ocorreu no dia $27 / 12 / 00$, no entanto grande parte desta foi infiltrada na área a montante do terraço de maneira que o menor volume de enxurrada proporcionou uma baixa taxa de infiltração no canal do terraço em todos tratamentos (Tabela 16). Nesse período, em que o solo encontravase menos úmido, pode-se perceber que os tratamentos de menor cobertura vegetal apresentaram as maiores taxas de infiltração de água no canal do terraço.

Neste tipo de análise de taxas de infiltração, desconsiderando a presença de fluxos abaixo de uma determinada camada, devem ser levados em consideração alguns fatos, como a localização dos sensores abaixo do nível da superfície do canal, proporcionando uma defasagem natural da resposta destes à armazenagem em relação ao tempo de duração da chuva, assim como a provável presença de drenagem profunda, fluxo lateral em direção ao camalhão do terraço e a evaporação. A desconsideração desses fatores pode incorrer em erros na estimativa das taxas, subestimando as taxas de infiltração nos canais dos terraços, em ambos os tratamentos. 


\subsubsection{Taxa de infiltração considerando fluxo a $0,30 \mathrm{~m}$}

Visando estimar as taxas de infiltração no canal considerando a ocorrência de fluxo utilizou-se a variação da armazenagem de água no canal até a profundidade de 0,30 $\mathrm{m}$ e a presença de fluxo abaixo desta para as mesmas chuvas de março e dezembro de 2000, desconsiderando a evaporação e o fluxo lateral (Figuras 32 e 33 e Tabela 17). De maneira geral, observa-se pela comparação entre as Figuras 32 e 30 que as taxas de infiltração estimadas no terraço para o mês de março, considerando ou não a presença de fluxo, mantiveram-se semelhantes após as chuvas dos dias 7 e 26/03/00 enquanto que após a chuva do dia 28/03/00 essas taxas aumentaram quando na consideração da presença de fluxo, principalmente no tratamento solo nu. Esse fato confirma que, desconsiderando a drenagem profunda, as taxas de infiltração no terraço são subestimadas, principalmente no tratamento solo nu que recebeu as maiores enxurradas.

Tabela 17. Fração de água da chuva infiltrada no canal do terraço $\left(f_{t}, m^{3} m^{-3}\right)$ e na área a montante $\left(f_{a}, \mathrm{~m}^{3} \mathrm{~m}^{-3}\right)$, considerando a presença de fluxo abaixo de $0,30 \mathrm{~m}$ para todos os tratamentos.

\begin{tabular}{ccccccccc}
\hline \multirow{2}{*}{ Data } & \multicolumn{2}{c}{ Grama } & \multicolumn{2}{c}{ Plantio direto } & \multicolumn{2}{c}{ Preparo convencional } & \multicolumn{2}{c}{ Solo nu } \\
\cline { 2 - 9 } & $\mathrm{f}_{\mathrm{a}}$ & $\mathrm{f}_{\mathrm{t}}$ & $\mathrm{f}_{\mathrm{a}}$ & $\mathrm{f}_{\mathrm{t}}$ & $\mathrm{f}_{\mathrm{a}}$ & $\mathrm{f}_{\mathrm{t}}$ & $\mathrm{f}_{\mathrm{a}}$ & $\mathrm{f}_{\mathrm{t}}$ \\
\hline $07 / 03 / 2000$ & 0,993 & 0,007 & 0,996 & 0,004 & 0,996 & 0,004 & 0,979 & 0,021 \\
$26 / 03 / 2000$ & 0,995 & 0,005 & 0,996 & 0,004 & 0,994 & 0,006 & 0,984 & 0,016 \\
$28 / 03 / 2000$ & 0,998 & 0,002 & 0,999 & 0,001 & 0,998 & 0,002 & 0,991 & 0,009 \\
& & & & & & & & \\
$04 / 12 / 2000$ & 0,997 & 0,003 & 0,999 & 0,001 & 0,996 & 0,004 & 0,979 & 0,021 \\
$16 / 12 / 2000$ & 0,998 & 0,002 & 0,999 & 0,001 & 0,998 & 0,002 & 0,991 & 0,009 \\
$27 / 12 / 2000$ & 0,999 & 0,001 & 0,998 & 0,002 & 0,999 & 0,001 & 0,986 & 0,014 \\
\hline
\end{tabular}

Ao comparar a Figura 31 com a Figura 33, percebe-se que as taxas de infiltração estimadas no canal após as chuvas dos dias 4 e 16/12/00 foram superiores às taxas encontradas quando da desconsideração dos fluxos na profundidade $0,90 \mathrm{~m}$. No entanto, no dia 27/12/00 praticamente não se percebe este fato. Essa constatação demonstra, mais uma vez, a dificuldade da estimativa dos fluxos de água e umidade do 
solo, pois se espera que, ao considerar a presença de fluxo (descendente após a chuva), a taxa de infiltração estimada seja maior do que desconsiderando esse fluxo.
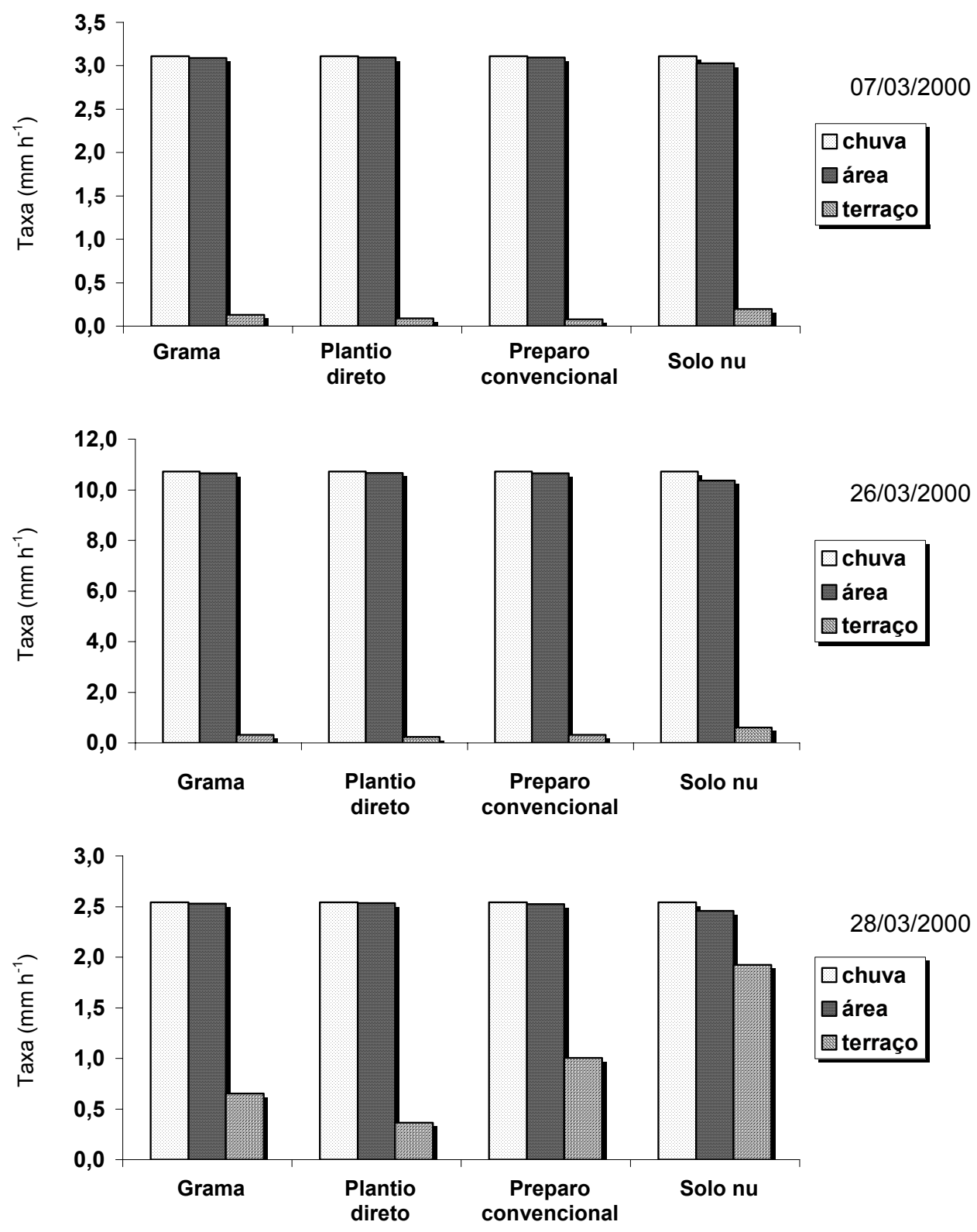

Figura 32 - Taxa de chuva e de infiltração da água no terraço e na área a montante do terraço nos dias $07 / 03 / 00,26 / 03 / 00$ e 28/03/00 para os tratamentos grama, plantio direto, preparo convencional e solo nu, considerando a armazenagem até a profundidade $0,30 \mathrm{~m}$ e a presença de fluxo abaixo desta. 

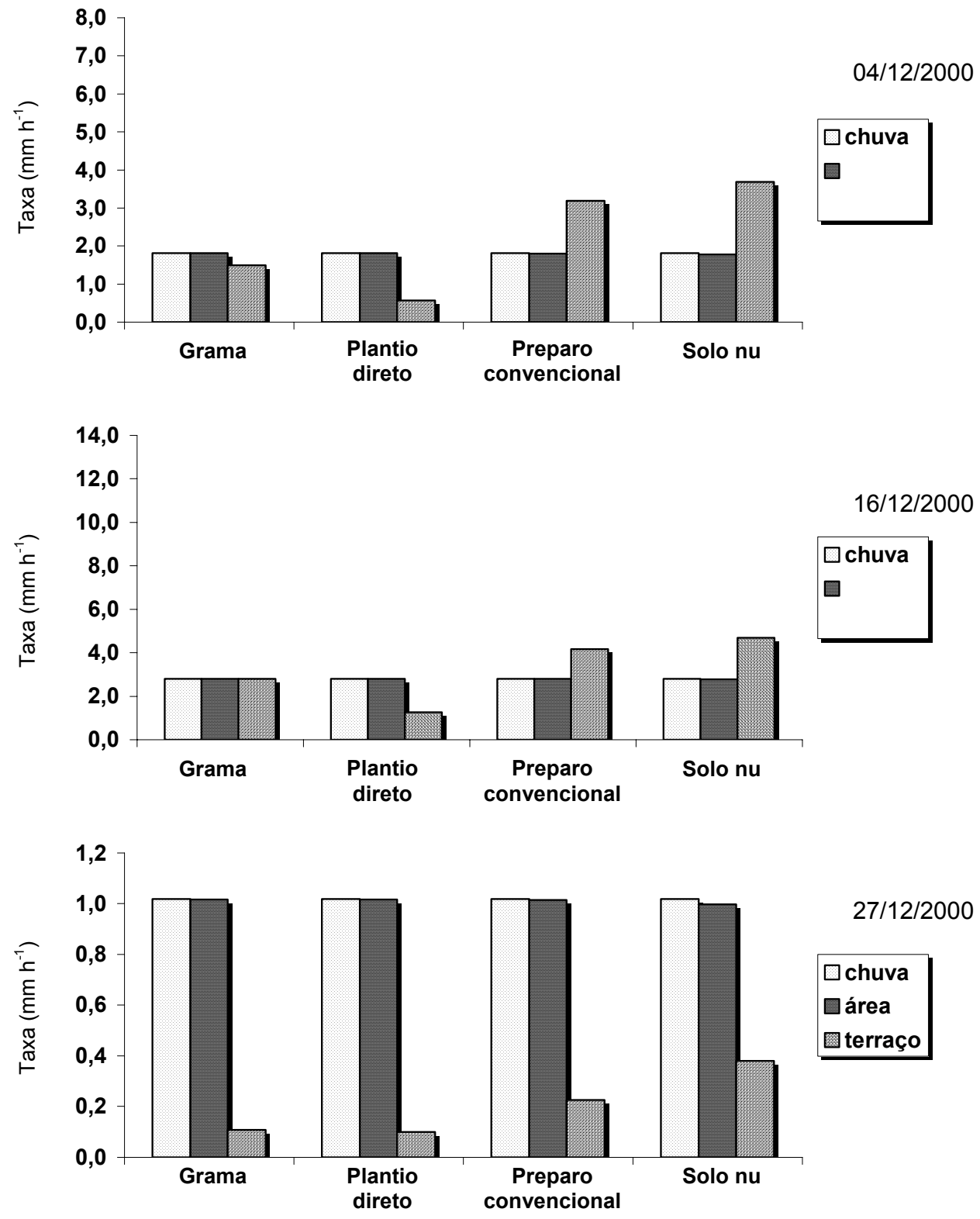

Figura 33 - Taxa de chuva e de infiltração da água no terraço e na área a montante do terraço nos dias $04 / 12 / 00,16 / 12 / 00$ e 27/12/00 para os tratamentos grama, plantio direto, preparo convencional e solo nu, considerando a armazenagem até a profundidade $0,30 \mathrm{~m}$ e a presença de fluxo abaixo desta. 


\section{CONCLUSÕES}

1. A alta variação comumente obtida entre repetições de determinação da condutividade hidráulica impede que se utilize a equação de DarcyBuckingham para calcular a densidade de fluxo da água próximo a superfície do canal, onde se deposita o material erodido. Assim, é inviável utilizar fluxos calculados por essa equação de base para estimar a taxa de infiltração em terraços em nível;

2. A conclusão 1 reforça-se pelas condições superficiais altamente variáveis encontradas em canais de terraços em nível devido a deposições irregulares do material erodido;

3. Uma metodologia para se realizar medições da umidade nas deposições sobre o canal deve ser desenvolvida para aumentar a acurácia da estimativa da armazenagem;

4. Devido às dificuldades na estimativa da umidade pelo TDR, não foi possível concluir quantitativamente sobre a capacidade de infiltração do canal do terraço;

5. A taxa de infiltração de água no canal do terraço não pode ser somente estimada pela variação da armazenagem da água no solo devido ao papel importante da drenagem profunda e, possivelmente, da absorção de água pela camalhão do terraço;

6. Uma adequada estimativa da taxa de infiltração no canal do terraço, imprescindível para seu dimensionamento, deve aliar um maior número de repetições, maior freqüência das leituras, além da medição da umidade no interior da camada de material depositado sobre o canal ao longo do tempo. 
ANEXOS 


\section{A1 - Descrição geral do solo da área experimental}

Classificação: Latossolo vermelho

Unidade: LV

Localização: trincheira aberta no ponto central da área experimental, localizada na

Fazenda Areão da Escola Superior de Agricultura "Luiz de Queiroz"/USP, município de Piracicaba.

Situação, declividade e cobertura vegetal sobre o perfil: terço superior da encosta, $8 \mathrm{~m} \mathrm{~m}^{-1}$ de declive, solo coberto por restos culturais de girassol sob plantio direto.

Erosão: entressulco moderada.

Relevo local: suave-ondulado.

Relevo regional: suave-ondulado.

Drenagem do perfil: bem drenado.

Pedregosidade : ausente.

Rochosidade: ausente.

Uso atual: área experimental de pesquisa em física e conservação do solo, atualmente em fase de implantação de terraços (outubro de 1999).

Descrito e coletado por: José Ronaldo Macedo, José Fernandes de Melo Filho

OBS: Considera-se o solo como sendo um Latossolo vermelho segundo mapa de classificação de solos da Fazenda Areão e por algumas características aqui descritas, apesar da espessura descrita para o horizonte A. Não foi possível a nova descrição deste horizonte por o solo apresenta-se com sua estrutura superficial bastante alterada e pela falta de um local representativo e acessível.

Informação adicional: Descrição química do solo da área experimental

\begin{tabular}{|c|c|c|c|c|c|c|c|c|c|c|c|c|c|c|}
\hline \multirow{2}{*}{$\begin{array}{l}\text { Prof. } \\
(\mathrm{cm})\end{array}$} & \multicolumn{3}{|c|}{$\mathrm{pH}$} & \multirow{2}{*}{$\begin{array}{c}\text { MO } \\
\left(\mathrm{g} \mathrm{kg}^{-1}\right)\end{array}$} & \multirow{2}{*}{$\begin{array}{c}\mathbf{P} \\
\left(\mathrm{mg} \mathrm{kg}^{-1}\right)\end{array}$} & $\mathrm{K}$ & $\mathrm{Ca}$ & $\mathrm{Mg}$ & A & $\mathrm{H}+\mathrm{Al}$ & SB & $\mathbf{T}$ & V & M \\
\hline & $\mathrm{H} 2 \mathrm{O}$ & $\mathrm{KCl}$ & $\mathrm{CaCl} 2$ & & & \multicolumn{7}{|c|}{$\left(\mathrm{mmol} \mathrm{kg}^{-1}\right)$} & \multicolumn{2}{|c|}{$(\%)$} \\
\hline $0-23$ & 6.4 & 4.3 & 4.5 & 23 & 14 & 0.7 & 31 & 20 & 6 & 62 & 51.7 & 113.7 & 45 & 10 \\
\hline $23-50$ & 4.7 & 3.7 & 3.8 & 15 & 5 & 0.4 & 12 & 10 & 21 & 84 & 22.4 & 106.4 & 21 & 48 \\
\hline $50-68$ & 5.8 & 3.8 & 3.8 & 15 & 4 & 0.2 & 5 & 4 & 21 & 78 & 9.2 & 87.2 & 11 & 70 \\
\hline $68-92$ & 4.6 & 3.7 & 3.8 & 13 & 4 & 0.2 & 12 & 8 & 22 & 81 & 20.2 & 101.2 & 20 & 52 \\
\hline $92-128$ & 5.5 & 3.8 & 3.8 & 13 & 4 & 0.3 & 10 & 5 & 20 & 70 & 15.3 & 85.3 & 18 & 57 \\
\hline $128-167$ & 4.7 & 3.8 & 3.9 & 13 & 2 & 0.2 & 10 & 5 & 15 & 63 & 15.2 & 78.2 & 19 & 50 \\
\hline $167+$ & 5.2 & 4.1 & 4.2 & 10 & 2 & 0.2 & 9 & 3 & 10 & 71 & 12.2 & 83.2 & 15 & 45 \\
\hline
\end{tabular}

$\mathrm{MO}=$ Método de Walkey Black; $\mathrm{H}+\mathrm{Al}$ = solução de acetato de cálcio $1 \mathrm{~N}$ a pH 7,0. 


\section{A2 - Descrição morfológica do solo da área experimental}

A $\quad \mathbf{0 - 2 3} \mathbf{c m}$, vermelho escuro (2,5YR 3/4, seco); vermelho escuro (2,5YR $3 / 4$, úmido); argilo arenoso; bloco sub-angular médio a grande; maciço, duro, plástico e pegajoso; transição clara plana.

A 23-50 cm, vermelho (2,5YR 4/4, seco); vermelho escuro (2,5YR 4/6, úmido); argilo arenoso; bloco sub-angular pequeno; cerosidade fraca, pouca; moderado, muito friável, plástico e pegajoso; transição difusa plana.

A $_{2}$ 50-68 cm, vermelho escuro (2,5YR 4/6, seco); vermelho escuro (2,5YR 4/6, úmido); argila; bloco sub-angular pequeno a médio; muito friável, muito friável, plástico e pegajoso; transição difusa plana.

A $_{3}$ 68-92 cm, vermelho escuro (2,5YR 4/6, seco); vermelho escuro (2,5YR 3/6, úmido); argila; bloco sub-angular pequeno a médio; friável, friável, plástico e pegajoso; transição clara plana.

AB 92-128 cm, vermelho escuro (2,5YR 4/6, seco); vermelho escuro (2,5YR 3/4, úmido); argila; bloco sub-angular pequeno a médio; friável, friável, plástico e pegajoso; transição clara plana.

BA 128-167 cm, vermelho escuro (2,5YR 4/6, seco); vermelho escuro (2,5YR 3/6, úmido); argila argiloso; bloco sub-angular pequeno a médio; friável, friável, muito plástico e muito pegajoso; transição clara plana.

B $167 \mathrm{~cm}^{+}$, vermelho escuro (2,5YR 4/6, seco); vermelho escuro (2,5YR 3/4, úmido); argila argiloso; bloco sub-angular pequeno a médio; bem friável, bem friável, muito plástico e muito pegajoso; transição clara plana.

OBS: Perfil muito alterado; atividade de formigas e cupins; raízes poucas e finas até $68 \mathrm{~cm}$ e quase ausentes de 68 a $167 \mathrm{~cm}^{+}$; presença de grânulos de carvão de tamanho pequeno em todos os horizontes; ausência de seixos, concreções e nódulos ao longo do perfil; sem poros visíveis no horizonte $A_{p}$, presença de muitos poros muito pequenos a pequenos nos horizontes $A, A_{2}, A_{3}$ e $A B$ e pequeno a médios nos horizontes $B A$ e $B$; drenagem boa em todo perfil. 


\section{REFERÊNCIAS BIBLIOGRÁFICAS}

ABRAMIDES NETO, J. Conservação do solo e da água pelo terraceamento. Revista de Agricultura, v.24, n.7/8, p.252-257, 1949.

ABRAMIDES NETO, J. O terraceamento e suas vantagens. Boletim de Agricultura, v.5, n.5/6, p.31-39, 1956.

ABRAMIDES NETO, J.; BORGONOVI, M. Tabelas para terraços. O Agronômico, v.1, p.93-106, 1941.

ABRAMIDES NETO, J.; MOURA, L.R. Como se aplicam as tabelas para terraceamento. Revista de Agricultura, v.18, n.7/8, p.215-227, 1943.

ALLMARAS, R. R.; BURWELL, R. E.; HOLT, R. F. Plow-layer porosity and surface roughness from tillage as affected by initial porosity and soil moisture at tillage time. Soil Science Society of America Proceedings, v.31, n.4, p.550-556, 1967.

ALLMARAS, R.R.; BURWELL, R.E.; LARSON, W.E.; HOLT, R.F. Total porosity and random roughness of the interrow zone as influenced by tillage. Washington: USDA ARS, 1966. 22p. (Cons. Res. Report, 7)

ASSIS, F.F. Banquetas individuais e plantio de cafeeiros em terrenos de encosta. Revista de Agricultura, v.29, n.10/11, p.297-302, 1954.

BAUMHARDT, R.L.; RÖMKENS,M.J.M; WHISLER, F.D.; PARLANGE, J.Y. Modeling infiltration into sealing soil. Water Resources Research, v.26, n.10, p.2497-2505, 1990. 
BERTOL, I.; COGO, N.P. Terraceamento em sistemas de preparo conservacionista de solo: um novo conceito. Lages: NRS-SBCS, 1996. 41p. (Boletim Técnico, 1)

BERTOL, I.; COGO, N.P.; LEVIEN, R. Relações da erosão hídrica com métodos de prepara do solo, na ausência e na presença de cobertura por resíduo cultural de trigo. Revista Brasileira de Ciência do Solo, v.11, n.2, p.187-192, 1987.

BERTOL, I.; COGO, N.P.; LEVIEN, R. Comprimento crítico de declive em sistemas de preparos conservacionistas de solo. Revista Brasileira de Ciência do Solo, v.21, n.1, p.139-148, 1997.

BERTOLINI, D.; GALETI, P.A.; DRUGOWICH, M.I. Tipos e formas de terraço. In: SIMPÓSIO SOBRE TERRACEAMENTO AGRÍCOLA, Campinas, 1988. Resumos. Campinas: Fundação Cargill, 1989. p.79-98.

BERTONI, J. Espaçamento de terraços para os solos do Estado. Piracicaba, 1957. 43p. Tese (Doutorado) - Escola Superior de Agricultura "Luiz de Queiroz", Universidade de São Paulo.

BERTONI, J. O espaçamento de terraços em culturas anuais, determinado em função das perdas por erosão. Bragantia, v.18, n.10, p113-140, 1959.

BERTONI, J. Terraço paralelo, nova técnica conservacionista. São Paulo Agrícola, v.17, p.40-41, 1960.

BERTONI, J.; LOMBARDI NETO, F. Conservação do solo. São Paulo: Ícone, 1990. $355 p$.

BERTONI, J.; LOMBARDI NETO, F.; BENATTI JR., R. Equação de perda de solo. Campinas: Instituto Agronômico, 1975. 25p. (Boletim Técnico, 21)

BLAKE, G.R.; HARTGE, K.H. Bulk density. In: KLUTE, A. (Ed.) Methods of soil analysis: physical and mineralogical methods. 2.ed. Madison: Soil Science Society of America, 1986. cap.13, p.363-375. 
BURWELL, R.E.; ALLMARAS, R.R.; AMEMIYA, M. A field measurement of total porosity and surface microrelief of soils. Soil Science Society of America Proceedings, v.27, n.6, p.697-700, 1963.

BURWELL, R.E.; ALLMARAS, R.R.; SLONEKER, L.L. Structural alteration of soil surfaces by tillage and rainfall. Journal of Soil and Water Conservation, v.21, n.2, p.61-63, 1966.

CANETTIERI, J.D. Construção de terraços - Processos tradicionais de construção. In: SIMPÓSIO SOBRE TERRACEAMENTO AGRÍCOLA, Campinas, 1988. Resumos. Campinas: Fundação Cargill, 1989. p.169-186.1989.

CASTRO, L.G. Erosão hídrica relacionada a rugosidade do solo na ausência e na presença de cobertura vegetal por resíduos de aveia. Porto Alegre, 1998. 120p. Dissertação (Mestrado) - Universidade Federal do Rio Grande do Sul.

CHAVES, H.M.L. Novo enfoque para o dimensionamento da área de seção transversal de terraços de retenção. Revista Brasileira de Ciência do Solo, v.20, n.1, p.141150, 1996.

CHAVES, H.M.L.; ORLOWSKI, E.; ROLOFF, G. Previsão da infiltração sob condições dinâmicas de selamento superficial. Revista Brasileira de Ciência do Solo, v.17, n.2, p.141-147, 1993.

CHOW, V.T. Applied hydrology. New York: McGraw-Hill, 1988. 572p.

CHU, S.T. Infiltration during unsteady rain. Water Resources Research, v.14, n.3, p.461-466, 1978.

CHU, S.T.; ONSTAD, C.A.; RAWLS, W.J. Field evaluation of leyered Green \& Ampt model for transient crust conditions. Transaction of the ASEA, v.29, n.5, p.12681272, 1277, 1986.

COGO, N.P. Effect of residue cover, tillage induce roughness, and slope lenght on erosion and related parameters. West Lafayette, 1981. 346p. Thesis (PhD) - Purdue University. 
CORREA, A.A.M. O terraceamento no combate à erosão. Coopercotia, v.14, n.104, p.17-20, 1958.

DAKER, A. Fatores que afetam a impermeabilização da superfície dos solos, causada pelos impactos dos pingos de chuvas. Revista Ceres, v.9, n.52, p.223-233, $1953 / 1954$.

DASBERG, S.; HOPMANS, J.W. Time Domain Reflectometry calibration for uniformly and nonuniformly wetted sandy and clayey loam soils. Soil Science Society of America Journal, v.56, p.1341-1345, 1992.

DIRKSEN, C. Soil physics measurements. Reiskirchen: Catena Verlag, 1999. 154p.

DIRKSEN, C.; DASBERG, S. Improved calibration of Time Domain Reflectometry soil water content measurements. Soil Science Society of America Journal, v.57, p.660-667, 1993.

DULEY, F.L. Surface factores affecting the rate of intake of water by soils. Soil Science Society of America Proceedings, v.4, p.60-64, 1939.

ELLISON, W.D. Soil erosion studies. Agricultural Engineering, v.28, p.145-147, $197-$ 201, 245-248, 297-300, 349-351, 402-405, 442-444, 1947.

ELTZ, F.L.F. Surface roughness changes as affected by tillage and rainfall erosivity. West Lafayette, 1993. 195p. Thesis (PhD) - Purdue University.

ELTZ, F.L.F.; REICHERT, J.M.; CASSOL, E.A. Período de retorno de chuvas em Santa Maria, RS. Revista Brasileira de Ciência do Solo, v.16, n.2, p.265-269, 1992.

EMPRESA BRASILEIRA DE PESQUISA AGROPECUÁRIA. Práticas de conservação de solos. Rio de Janeiro: SNLCS, 1980. 85p. (Série Miscelânea, 3)

FOX, D.M.; BISSONNAIS, Y.; QUÉTIN, P. The implications of variability in surface seal hydraulic resistence for infiltration in a mound and depression microtopography. Catena, v.32, p.101-104, 1998. 
FREIRE, J.C. Condutividade hidráulica e capacidade de campo de Latossolo roxo distrófico não saturado. Revista Brasileira de Ciência do Solo, v.3, n.2, p.73-77, 1979.

FREIRE, O.; PESSOTTI, J.E.S. Erodibilidade dos solos de Piracicaba. Revista de Agricultura, v.51, n.3/4, p.195-202, 1976.

GEE, G.W.; BAUDER, J.C. Particle size analysis. In: KLUTE, A. (Ed.) Methods of soil analysis: physical and mineralogical methods. 2.ed. Madison: Soil Science Society of America, 1986. cap.15, p.383-409.

GREEN, R.E.; AHUJA, L.R.; CHONG, S.K. Hydraulic conductivity diffusivity and sorptivity of unsaturated soils: field methods. In: KLUTE, A. (Ed.) Methods of soil analysis: physical and mineralogical methods. 2.ed. Madison: Soil Science Society of America, 1986. cap.30, p.771-796.

GRIEBELER, N.P.; CARVALHO, D.F.; MATOS, A.T. Estimativa do custo de implantação de sistema de terraceamento, utilizando-se SIG. Estudo de caso: bacia do Rio Caxangá, PR. Revista Brasileira de Engenharia Agrícola Ambiental, v.4, n.2, p.299-303, 2000.

HEIL, J.W.; JOU, A.S.R.; McINNES, K.J. Soil Properties influencing surface sealing of some sandy soils in the Sahel. Soil Science, v.162, p.459-469, 1997.

HILLEL, D.A.; KRENTOS, V.K.; STILIANOV, Y. Procedure and test of an internal drainage method for measuring soil hydraulic characteristics in situ. Soil Science, v.114, p.395-400, 1972.

HUDSON, N. Soil conservation. Ames: lowa State University Press, 1995. 391p.

JACOBSEN, O.H.; SCHJONNING, P. A laboratory calibration of Time Domain Reflectometry for soil water measuremet including effects of bulk density and texture. Journal of Hydrology, v.151, p.147-157, 1993.

JONG VAN LIER, Q.; LIBARDI, P.L. Variabilidade dos parâmetros da equação que relaciona a condutividade hidráulica com a umidade do solo no método do perfil instantâneo. Revista Brasileira de Ciência do Solo, v.23, n.4, p.1005-1014,1999. 
KLUTE, A. Water retention: Laboratory methods. In: KLUTE, A. (Ed.) Methods of soil analysis: physical and mineralogical methods. 2.ed. Madison: Soil Science Society of America, 1986. cap.26, p.635-660.

LEMOS, M.S.S.; BAHIA, V.G. Erosividade da chuva. Informe Agropecuário, v.16, n.176, p.25-31, 1992.

LEMOS, R.C.; SANTOS, R.D. Manual de descrição e coleta de solo no campo. 3.ed. Campinas: SBCS, 1996. 83p.

LEVIEN, R.; JONG VAN LIER, Q.; ALVES, A.G.C. Influence of surface crust on water infiltration rates measured by a rotating-boom rainfall simulator and double-cylinder device. Revista Brasileira de Ciência do Solo. v.24, n.3, p.479-486, 2000.

LIBARDI, P.L.; REICHARDT, K.; NIELSEN, D.R.; BIGGAR, J.W. Simple field methods for estimating soil hydraulic conductivity. Soil Science Society of America Journal, v.44, p.3-7, 1980.

LIDEU, J.; RIDDER, P.; CLERK, P.; DAUTREBANDE, S. A method of measuring soil moisture by Time-Domain Reflectometry. Journal of Hydrology, v.88, p.319-328, 1986.

LIMA, P.M.P.; BAHIA, V.G.; CURI, N.; SILVA, M.L.N. Princípios de erodibilidade do solo. Informe Agropecuário, v.16, n.176, p.38-43,1992.

LOMBARDI NETO, F. Dimensionamento do canal do terraço. In: SIMPÓSIO SOBRE TERRACEAMENTO AGRÍCOLA, Campinas, 1988. Resumos. Campinas: Fundação Cargill, 1989. p.125-135.

LOMBARDI NETO, F.; BERTONI, J. Erodibilidade dos solos paulistas. Campinas: Instituto Agronômico, 1975. 12p. (Boletim Técnico, 27)

LOMBARDI NETO, F.; BELLINAZZI JR., R.; GALETI, P.A.; BERTOLINI, D.; LEPSCH, I.F.; OLIVEIRA, J.B. Nova abordagem para cálculo de espaçamento entre terraços. In: SIMPÓSIO SOBRE TERRACEAMENTO AGRÍCOLA, Campinas, 1988. Resumos. Campinas: Fundação Cargill, 1989. p.99-124. 
LOMBARDI NETO, F.; BELLINAZZI JR., R.; LEPSCH, I.F.; OLIVEIRA, J.B.; BERTOLINI, D.; GALETI, P.A.; DRUGOWICH, M.I. Terraceamento agrícola. In: BERTOLINI, D.; LOMBARDI NETO, F.; LEPSCH, I.F.; OLIVEIRA, J.B.; DRUGOWICH, M.I; ANDRADE, N.O.; GALETI, P.A.; BELLINAZZI JR., R.; DECHEN, S.C.F. Manual técnico de manejo e conservação de solo e água. Campinas: CATI, 1994a. V.4: Tecnologias disponíveis para controlar o escorrimento superficial do solo, p.11-35. (Manual Técnico, 41)

LOMBARDI NETO, F.; BELLINAZZI JR., R.; LEPSCH, I.F.; OLIVEIRA, J.B.; BERTOLINI, D.; GALETI, P.A.; DRUGOWICH, M.I. Terraceamento agrícola. 2.ed. Campinas: CATI, 1994b. 39p. (Boletim Técnico, 206)

LOPES, P.R.C.; COGO, N.P.; CASSOL, E.A. Influência da cobertura vegetal morta na redução da velocidade da enxurrada e na distribuição de tamanho dos sedimentos transportados. Revista Brasileira de Ciência do Solo, v.11, n.2, p.193-197, 1987a.

LOPES, P.R.C.; COGO, N.P.; LEVIEN, R. Eficácia relativa de tipo e quantidade de resíduos culturais espalhados uniformemente sobre o solo na redução da erosão hídrica. Revista Brasileira de Ciência do Solo, v.11, n.1, p.71-75, 1987 b.

MARTINS, M.V.; BAHIA, V.G. Tecnologias disponíveis para controle do escoamento superficial. Informe Agropecuário, v.19, n.191, p.28-34, 1998.

MORAIS, L.F.B.; MUTTI, L.S.M.; ELTZ, F.L.F. Índices de erosividade correlacionados com perdas de solo no Rio Grande do Sul. Revista Brasileira de Ciência do Solo, v.12, n.3, p.281-284, 1988.

OLIVEIRA, G.C.; PEREIRA, J.C.; MESQUITA, M.G. Espaçamento de terraços em função dos fatores que afetam as perdas por erosão. Informe Agropecuário, v.16, n.176, p.44-50, 1992.

PEPIN, S.; LIVINGSTON, N.J.; HOOK, W.R. Temperature-dependent measurement errors in Time Domain Reflectometry determinations of soil water. Soil Science Society of America Journal, v.59, p.38-43, 1995. 
PONIZOVSKY, A.A.; CHUDINOVA, S.M.; PACHEPSKY, Y.A. Performance of TDR calibrations models as affected by soil texture. Journal of Hydrology, v.218, p.3543, 1999.

PREVEDELLO, B.M.S.; PREVEDELLO, C.L.; LIBARDI, P.L. Simplificação analítica do método do perfil instantâneo para obtenção da condutividade hidráulica não saturada em condições de campo. Revista Brasileira de Ciência do Solo, v.5, n.2, p.93-97, 1981.

PREVEDELLO, C.L.; REICHARDT, K.; CORDEIRO, D.G.; MELO, E.F.R.Q.; SCHEFFER, M. Gradiente unitário do potencial hidráulico como fonte de erro na obtenção da condutividade hidráulica em solo não-saturado. Pesquisa Agropecuária Brasileira, v.29, n.2, p.275-280, 1994.

PRUSKI, F.F.; FERREIRA, P.A.; RAMOS, M.M.; CECON, P.R. Parâmetros para o dimensionamento e manejo de sistemas de conservação de solos com terraços posicionados em nível, em treze municípios paranaenses. Engenharia na Agricultura, v.3, n.35, p.1-13, 1994.

PRUSKI, F.F.; FERREIRA, P.A.; RAMOS, M.M.; CECON, P.R. Model to desing level terraces. Journal of Irrigation and Drainage Engineering, v.123, n.1, p.8-12, 1997.

REICHARDT, K.; PORTEZAN, O.; LIBARDI, P.L.; BACCHI, O.O.S.; MORAES, S.O.; OLIVEIRA, J.M.C.; FALLEIROS, M.C. Critical analysis of the field determination of soil hydraulic conductivity funtions using the flux gradiente approach. Soil \& Tillage Research, v.48, p.81-89, 1998.

RODRIGUES, N.S. Rompimento de terraços. In: CONGRESSO NACIONAL DE CONSERVAÇÃO DO SOLO, Campinas, 1963. Anais. São Paulo: Secretaria da Agricultura, 1963. p.364-369.

SCHMUGGE, T.J.; JACKSON, T.J.; McKIM, H.L. Survey of methods for soil moisture determination. Water Resouces Reseach, v.16, n.6, p.961-979, 1980. 
SCHWAB, G.O.; FANGMEIER, D.D.; ELLIOT, W.J.; FREVERT, R.K. Soil and water conservation engineering. 4.ed. New York: John Wiley \& Sons, Inc., 1993. 507p.

SILVA, A.M. Hidráulica dos terraços. Informe Agropecuário, v.19, n.191, p.35-38, 1998.

SINGER, M.J.; BISSONNAIS, Y.L. Importance of surface sealing in the erosion of some soils from a mediterranean climate. Geomorphology, v.24, p.79-85, 1998.

SMITH, D.D.; WISCHMEIER, W.H. Rainfall erosion. Advances in Agronomy, v.14, p.109-148, 1962.

SWANSON, N.P.; DEDRICK, A.R.; WEAKLY, H.E.; HAISE, H.R. Evaluation of mulches for water-erosion control. Transaction of the ASAE, v.8, p.438-440, 1965.

TERRACEAMENTO planejado garante contrôle da erosão. O Dirigente Rural, v.7, n.5, p.46-50, 1968.

TOMASELLI, J.T.G. Influência de algumas características do solo sobre a calibração de um aparelho TDR (Time-Domain Reflectometry). Piracicaba, 1997. 109p. Tese (Doutorado) - Centro de Energia Nuclear na Agricultura, Universidade de São Paulo.

TOPP, G.C.; DAVIS, J.L. Detecting infiltration of water through soil cracks by timedomain reflectometry. Geoderma, v.26, p.13-23, 1981.

TOPP, G.C.; DAVIS, J.L.; ANNAN, A.P. Eletromagnetic determination of soil water content: Measurements in coaxial transmission lines. Water Resouces Research, v.16, n.3, p.574-582, 1980.

TOPP, G.C.; DAVIS, J.L.; ANNAN, A.P. Eletromagnetic determination of soil water content using TDR: I. Aplications to wetting fronts and steep gradients. Soil Science Society of America Journal, v.46, p.672-678, 1982.

TRUMAN, C.C.; BRADFORD, J.M. Effects of antecedent soil moisture on splash detachment under simulated rainfall. Soil Science, v.150, n.5, p.787-798, 1990. 
VAN GENUCHTEN, M.Th; NIELSEN, D.R. A closed - form equation for predicting the hydraulic conductivity of unsaturated soils. Soil Science Society of America Journal, v.44, p.892-898, 1980.

WARRICK, A.W.; NIELSEN, D.R. Spacial variability of soil physical properties in the field. In: HILLEL, D. (Ed). Applications of soil physics. New York: Academic Press, 1980. p.319-344.

WEBSTER, R.; OLIVER, M.A. Sample adequately to estimate variograms of soil properties. Journal Soil Science, v.43, p.177-192, 1992.

WISCHMEIER, W.H. A rainfall erosion index for a universal soil-loss equation. Soil Science Society of American Proceedings, v.23, n.3, p.246-249, 1959.

WISCHMEIER, W.H. Conservation tillage to control water erosion. In: NATIONAL CONSERVATION TILLAGE CONFERENCE, Ankeny, 1973. Proceedings. Ankeny: Soil Conservation Society of American, 1973. p.133-141.

WISCHMEIER, W.H.; MANNERING, J.V. Relation of soil properties to its erodibility. Soil Science Society of American Proceedings, v.33, n.1, p.131-137, 1969.

WISCHMEIER, W.H.; SMITH, D.D. Predicting rainfall erosion losses: a guide to conservation planning. Washington: USDA, 1978. 58p. (Agricultural Handbook, 537)

WISCHMEIER, W.H.; JOHNSON, C.B.; CROSS, B.V. A soil erodibility nomograph for farmland and construction sites. Journal of Soil and Water Conservation, v.26, p.189-193, 1971.

YU, C.; WARRICK, A.W.; CONKLIN, M.H. Derived functions of time domain reflectometry for soil moisture measurement. Water Resourses Research. v.35, n.6, p.1789-1796, 1999.

YU, C.; WARRICK, A.W.; CONKLIN, M.H.; YOUNG, M.H.; ZREDA, M. Two-threeparameter calibrations of time domain reflectometry for soil moisture measurement. Water Resourses Research. v.33, n.10, p.2417-2421, 1997. 
ZENKER, R. Por que terraços de base larga. Trigo e Soja, n.37, p.11-15, 1978.

ZINGG, A.W. Degree and length of land slope as it affects soil loss in runoff. Agricultural Engineering, v.21, p.59-64, 1940. 